\title{
Marine Terpenoids from Polar Latitudes and Their Potential Applications in Biotechnology
}

\author{
Laura Núñez-Pons ${ }^{1}$, Andrew Shilling ${ }^{2}$, Cinzia Verde ${ }^{3,4}$, Bill J. Baker ${ }^{2, *}$ (I) and \\ Daniela Giordano ${ }^{3,4, * \text { (D) }}$ \\ 1 Department of Integrated Marine Ecology (EMI), Stazione Zoologica Anton Dohrn (SZN), Villa Comunale, \\ 80121 Napoli, Italy; laura.nunezpons@szn.it \\ 2 Department of Chemistry, University of South Florida, Tampa, FL 33620, USA; ashillin@mail.usf.edu \\ 3 Institute of Biosciences and BioResources (IBBR), CNR, Via Pietro Castellino 111, 80131 Napoli, Italy; \\ cinzia.verde@ibbr.cnr.it \\ 4 Department of Marine Biotechnology, Stazione Zoologica Anton Dohrn (SZN), Villa Comunale, \\ 80121 Napoli, Italy \\ * Correspondence: bjbaker@usf.edu (B.J.B.); daniela.giordano@ibbr.cnr.it (D.G.)
}

Received: 25 June 2020; Accepted: 25 July 2020; Published: 29 July 2020

\begin{abstract}
Polar marine biota have adapted to thrive under one of the ocean's most inhospitable scenarios, where extremes of temperature, light photoperiod and ice disturbance, along with ecological interactions, have selected species with a unique suite of secondary metabolites. Organisms of Arctic and Antarctic oceans are prolific sources of natural products, exhibiting wide structural diversity and remarkable bioactivities for human applications. Chemical skeletons belonging to terpene families are the most commonly found compounds, whereas cytotoxic antimicrobial properties, the capacity to prevent infections, are the most widely reported activities from these environments. This review firstly summarizes the regulations on access and benefit sharing requirements for research in polar environments. Then it provides an overview of the natural product arsenal from Antarctic and Arctic marine organisms that displays promising uses for fighting human disease. Microbes, such as bacteria and fungi, and macroorganisms, such as sponges, macroalgae, ascidians, corals, bryozoans, echinoderms and mollusks, are the main focus of this review. The biological origin, the structure of terpenes and terpenoids, derivatives and their biotechnological potential are described. This survey aims to highlight the chemical diversity of marine polar life and the versatility of this group of biomolecules, in an effort to encourage further research in drug discovery.
\end{abstract}

Keywords: Arctic/Antarctic; marine bioprospecting; marine natural product; terpene; terpenoid; biotechnological application; drug discovery

\section{Foreword}

The global market for marine biotechnology is expected to reach US $\$ 6.4$ billion by 2025 [1]. However, in regard to the polar regions, marine biotechnology has lagged and the potential for many sectors is not yet fully realized. These remote and underexploited habitats are promising sources of environmental and biomedical applications and may provide significant opportunities for compound discovery and bioprospecting [2-6].

The Arctic Ocean ( 4.3\% of Earth's ocean area) and the meridional part of the Southern Ocean (south of the Antarctic Convergence, $\sim 6.1 \%$ of Earth's ocean area) comprise the Polar Seas [7]. In the coldest years, the sea ice cover in these areas can reach up to $\sim 13 \%$ of Earth's total surface. The Arctic Ocean is delineated by the International Hydrographic Organization (https://iho.int) as the body of water north of $57^{\circ}$ from Earth's equatorial plane. It is mainly characterized by light seasonality and 
cold temperatures with winter extremes, and comprises a vast ocean accessible to an influx of warm water from the Atlantic and the Pacific Oceans [8]. The Antarctic Ocean encompasses the body of water between $60^{\circ}$ South latitude and the continent of Antarctica (https://iho.int). Known as being the driest, windiest and coldest place on Earth, the white continent is isolated from the other continents, geographically and thermally by the Antarctic Circumpolar Current. Its northern border, the Antarctic Polar Front, represents a barrier for latitudinal migration of marine organisms, which renders the local biota as highly endemic [9-11].

Some evidence indicates that the events that generated the confinement of Antarctica occurred about 34 million years ago around the Eocene/Oligocene limit [12]. Polar marine life has evolved to thrive at one of life's extreme limits, with liquid water that cannot get any colder and long periods of darkness, which has selected for species with unique adaptations, including strategies based on often unique secondary metabolites $[13,14]$.

Indeed, the distinctive environment and ecological pressures faced by marine wildlife in polar regions are major drivers of secondary metabolite production and the emergence of compounds with diverse biological activities [15]. Competition for space and food, predator avoidance, pathogen threat and, in general, intra-species chemical communication, promote chemical diversity in marine environments [16]. In addition, marine polar organisms require sophisticated biochemical and physiological adaptations to cope with low temperatures, strong winds, arrested nutrient availability and high UV radiation [6]. Therefore, under extreme polar scenarios, bioactive compounds in the form of secondary metabolites are of major relevance for the survival of marine organisms [13].

Although compounds with varied biotechnological properties have been identified in polar organisms, the most commonly reported activity is toward pathogenic infections. Discovering novel and efficient antimicrobial metabolites is imperative, due to the increasing emergence of antibiotic-resistant or even multidrug-resistant strains of microorganisms [17].

In this review, we first expose the framework regarding the regulations that govern access and benefit sharing requirements in polar environments, and secondly, we report bioactive compounds isolated from marine bacteria, fungi and macroorganisms inhabiting Arctic and Antarctic environments. In particular, the present survey focuses on marine terpenes and their derivatives harboring properties with potential impact on pharmacological remedies towards human diseases.

\section{Marine Biotechnology: Governance, Access and Benefit Sharing in the Antarctic and Arctic Environments}

Marine natural products have attracted growing commercial interest from the biotech sector, supporting a rich marine biodiscovery pipeline [18]. The global market for marine-derived pharmaceuticals is around US\$5 billion [19]. However, despite successful discoveries, few drugs isolated from marine organisms have been approved by the US Food and Drug Administration (FDA) [19-21], e.g., anticancer drugs such as cytarabine (Cytosar- $\left.{ }^{\circledR}{ }^{\circledR}\right)$ from the Caribbean sponge Tectitethya crypta (=Cryptotethya crypta) [22], trabectedin (Yondelis ${ }^{\circledR \circledR}$ ) from the ascidian Ecteinascidia turbinata [23], eribulin (Halaven ${ }^{\circledR}$ ) from the sponge Halichondria okadai, the antiviral vidarabine from the sponge Tethya crypta and the analgesic ziconotide (Prialt $\left.{ }^{\circledR}{ }^{\circledR}\right)$ from the sea snail Conus magus [22].

Technological advances are swiftly reducing sequencing costs as demonstrated by the exponential growth of data freely available of public repositories (INSDC, comprising GenBank, EMBL-EBI/ENA and DDBJ) [24]. Nevertheless, there is an urgent need for services able to handle and harmonize the information obtained by heterogeneous standards. In addition, stakeholders, academia, industry, funding agencies, infrastructure providers and scholarly publishers should promote the FAIR (Findable, Accessible, Interoperable and Reusable) concepts. As yet, the Nagoya Protocol on Access to Genetic Resources and the Fair and Equitable Sharing of Benefits Arising from their Utilization of 2010 ("Nagoya Protocol") does not apply to some areas of the ocean [25].

The Convention on Biological Diversity (CBD) [19] defines bioprospecting as the exploration and development of knowledge of genetic and biochemical resources for commercial purposes. 
From the perspective of protecting biodiversity, the CBD and the Nagoya Protocol are the most important agreements. The Nagoya Protocol aims to support and supplement domestic legislation by defining the genetic resources and the contractual obligations to be written in mutually agreed terms. The CBD introduced novel legal concepts such as biodiversity, ecosystems, genetic resources, biotechnology, benefit sharing and traditional knowledge. Applying the CBD in Antarctica is no simple matter and still requires more explicit regulation [26-28].

Antarctica represents a space exclusively dedicated to international cooperation where states are not able to exercise sovereign rights. Antarctica is governed by its own regional regime, the Antarctic Treaty System (ATS). Essential to the ATS is the Antarctic Treaty (AT, 1959), which applies to the area south of $60^{\circ}$ South latitude. The ATS is composed of five main treaties: the AT, the Convention for the Conservation of Antarctic Seals (1971), the Convention on the Conservation of Antarctic Marine Living Resources (CCAMLR 1980), the Convention on the Regulation of Antarctic Mineral Resource Activities (1988) and the Madrid Protocol amendment to the AT (1991). Article III of the AT requires that parties cooperate by sharing information on research results. Article II of the AT acknowledges the importance of the freedom of scientific investigation $[29,30]$.

Bioprospecting is a rapidly accelerating activity in Antarctica with new players such as Malaysia with strong commercial interests in Antarctic organisms [31,32]. Terrestrial and marine biological material from Antarctica can be accessed either by collecting specimens from the field or from ex situ collections of Antarctic Biological Material (ABM) held in institutions around the world [26]. Bioprospecting was first discussed within the ATS in 1999. Since then it has received regular attention at meetings of the Scientific Committee on Antarctic Research (SCAR) [33], Committee for Environmental Protection (CEP) and the Antarctic Treaty Consultative Meeting (ATCM). Despite being a consistent topic at every ATCM since 2002, there are still many gaps to manage bioprospecting expectations and activities in Antarctica. CCAMLR may regulate travel to Antarctica but cannot legislate commercial profit from bioprospecting.

Antarctica is a hot spot for bioprospecting. A recent study reported patents for 439 Antarctic species that illustrate the great diversity of potential applications from marine cold-adapted organisms [34].

Bioprospecting is also developing in the Arctic, linked to regional features and the role of enterprises both large and small. Five nations, Canada, Denmark, Norway, Russia and the United States, are currently seeking to increase their territory in the Arctic. Companies from North America, Norway, Iceland, Finland, Sweden, Denmark and the United Kingdom are actively developing new biotechnologies based on genetic resources found in the Arctic [35]. Biotechnology research in the Arctic is mainly focused on industrial processes, food technology, pollution control technologies, pharmaceutical and medical products and health related advancements. More than 40 companies are now involved in bioprospecting in the Arctic largely attracted by the unexplored space and unusual biology of Arctic organisms that promise to open new opportunities in applied research [36]. In 2008, Leary [37] noted the recent rise in the number of patents derived from Arctic genetic resources, though no new reviews have appeared in the intervening $10+$ years. Norway is leading projects in marine Arctic bioprospecting mostly focused on the Arctic and sub-Arctic waters. In March 2007, the Research Council of Norway launched MabCent-SFI, a marine bioprospecting project to discover and develop high-value, marine-based products for antibacterial, anticancer, anti-inflammatory products, antioxidants and diabetes medicine, as well as novel cold-adapted enzymes.

\section{Marine Compounds from Polar Regions}

In 2018, 1554 new natural products from polar marine sources were reported, revealing a number of pharmacologically interesting activities [38]. Of the more than 30,000 publications on marine natural products that have been produced, less than $3 \%$ were focused on studies from polar environments, largely due to the difficult accessibility and logistics and associated costs $[5,16]$. The majority of these cold-water natural products up to 2005 came from marine macroorganisms (e.g., sponges, ascidians, mollusks and corals). After 2005, thanks to advances in sampling methodologies and increased access 
to previously inaccessible areas, natural products isolated from marine polar microorganisms increased from $22 \%$ to $71 \%$. Indeed, microbes have turned into a prolific resource for novel chemistry and the sustainable production of bioactive metabolites, overcoming the problem of recollection of samples from the field, which is required for macroorganisms [5].

Polar microorganisms have been used in many biotechnological applications for the production of bioactive molecules, including enzymes [4] for industrial processes such as food technology and natural compounds with antimicrobial, anti-inflammatory and anticancer activities $[5,16]$. Moreover, cold-adapted fungi and bacteria are considered a source of (i) antifreeze proteins [39] to be used in the food industry [40-42], and for biomedical purposes [43,44]; (ii) extracellular polymeric substances (EPSs), already used in the textile, cosmetic and food industry $[45,46]$, in the remediation of heavy-metal contaminated environments, including low temperature applications [47], and in the pharmaceutical industry [48]; (iii) polyunsaturated fatty acids (PUFA) as promising alternatives to fish oils in the food industry $[39,49,50]$.

Natural compounds with antimicrobial, anti-inflammatory and anticancer activities have been isolated from marine invertebrates in the Arctic region [3,51-53] and in the marine Antarctic environment [54-57].

Bioactive compounds recovered from host invertebrates may be produced by their microbial symbionts in the marine environment $[58,59]$. Although the ecological function of bacteria-invertebrate interactions in polar areas is only poorly understood, it seems that microbial metabolites may have crucial roles in host-associated chemical defenses and in shaping the symbiotic community structure [60]. Fungi and bacteria isolated from polar sponges and algae, for instance, show wide spectrum antibacterial activity against many microorganisms [61-69].

Bacteria and fungi, as representative of microbial biodiversity, and macroorganisms, such as sponges, macroalgae, ascidians, corals, bryozoans, echinoderms and mollusks, are the target biological taxa of our review. In Table 1 we list purified marine natural products with elucidated structures isolated from organisms inhabiting the polar environments, focusing mostly on those evaluated for biological activity against human pathogens. We excluded studies evaluating crude extracts or impure fractions for bioactivity, while some relevant ecological activities have been highlighted in the table. 
Table 1. Bioactive compounds from Polar marine bacteria, fungi, cnidaria, bryozoa, mollusca, echinodermata, sponges, tunicates and macroalgae.

\begin{tabular}{|c|c|c|c|c|c|}
\hline Species & $\begin{array}{l}\text { Collection Site } \\
\text { (Distribution) }\end{array}$ & Compound & Molecule Type & Bioactivity & Reference \\
\hline \multirow{3}{*}{ Arthrobacter sp. } & \multicolumn{5}{|c|}{$\begin{array}{c}\text { BACTERIA } \\
\text { Plylum Actinobacteria } \\
\text { Class Actinobacteria }\end{array}$} \\
\hline & $\begin{array}{l}\text { Marine sediment, Terranova } \\
\text { Bay, Ross Sea (Antarctica); }\end{array}$ & monoramnholipids & rhamnolipid & $\begin{array}{l}\text { Antimicrobial activity against } \\
\text { Burkholderia cepacia complex }\end{array}$ & [70] \\
\hline & $\begin{array}{l}\text { Surface water, sea ice, } \\
\text { zooplankton, the deep sea, and } \\
\text { meltwater (Arctic Ocean) }\end{array}$ & arthrobacilins A-C & cyclic glycolipids & $\begin{array}{l}\text { Antimicrobial activity against Vibrio } \\
\text { anguillarum and Staphylococcus aureus }\end{array}$ & [71] \\
\hline Nocardia dassonvillei & $\begin{array}{l}\text { Marine sediment } \\
\text { (Arctic Ocean) }\end{array}$ & $\begin{array}{l}\text { N-(2-hydroxyphenyl)-2-phenazinamine, } \\
\text { 1,6-dihydroxyl-phenazine, 6-hydroxyl } \\
\text { phenazine-1-carboxylic acid, 6-methoxy-1-phenazinol, } \\
\text { 2-amino-1, 4-naphthoquinone, 2-amino-phenoxazin-3-one } \\
\text { and 2-(N-methylamino)-3-phenoxazone }\end{array}$ & $\begin{array}{l}\text { phenazine, phenoxazine, } \\
\text { naphthoquinone }\end{array}$ & $\begin{array}{l}\text { Antifungal activity against Candida } \\
\text { albicans and high cancer cell } \\
\text { cytotoxicity against HepG2, A549, } \\
\text { HCT-116 and COC1 cells }\end{array}$ & [72] \\
\hline Nocardiopsis SCSIO KS107 & $\begin{array}{l}\text { Seashore sediment sample, } \\
\text { China Great Wall station } \\
\text { (Antarctica) }\end{array}$ & 7-hydroxymucidone, 4-hydroxymucidone, germicidin $\mathrm{H}$ & $\alpha$-pyrones & $\begin{array}{l}\text { Antibacterial activity against } \\
\text { Micrococcus luteus and Bacillus subtilis }\end{array}$ & [73] \\
\hline \multirow[b]{2}{*}{ Rhodococcus sp. B7740 } & \multirow{2}{*}{$\begin{array}{l}\text { Deep seawater } \\
\text { (Arctic Ocean) }\end{array}$} & isorenieratene (116) & carotenoid & Antioxidant activity & {$[74,75]$} \\
\hline & & menaquinone $\mathrm{MK}_{8}\left(\mathrm{H}_{2}\right)(\mathbf{1 1 5})$ & isoprenoid quinone & $\begin{array}{c}\text { Antioxidant and antiglycation } \\
\text { activities }\end{array}$ & [76] \\
\hline Streptomyces sp. & $\begin{array}{l}\text { Marine surface sediment of the } \\
\text { East Siberian continental } \\
\text { margin (Arctic Ocean) }\end{array}$ & arcticoside, C-1027 chromophore-V, III, fijiolides A and B & $\begin{array}{l}\text { benzoxazines, } \\
\text { glycosylated } \\
\text { paracyclophane }\end{array}$ & $\begin{array}{l}\text { Cytotoxic activity against breast } \\
\text { carcinoma MDA-MB231 cells and } \\
\text { colorectal carcinoma cells } \\
\text { (line HCT-116) }\end{array}$ & [77] \\
\hline Streptomyces strain 1010 & $\begin{array}{l}\text { Shallow sea sediment from the } \\
\text { region of Livingston Island } \\
\text { (Antarctica) }\end{array}$ & $\begin{array}{c}\text { phthalic acid diethyl ester, } \\
\text { 1,3-bis(3-phenoxyphenoxy)benzene, exanedioic acid } \\
\text { dioctyl ester, 2-amino-9,13-dimethyl heptadecanoic acid }\end{array}$ & aromatic compounds & No activity tested * & [78] \\
\hline Streptomyces sp. SCO736 & Marine sediment (Antarctica) & $\operatorname{antartin}(\mathbf{1 0})$ & $\begin{array}{l}\text { zizaane-type } \\
\text { sesquiterpene }\end{array}$ & $\begin{array}{l}\text { Cytotoxic activity against A549, } \\
\text { H1299 and U87 cancer cell lines by } \\
\text { causing cell cycle arrest at the } \\
\text { G1 phase }\end{array}$ & [79] \\
\hline $\begin{array}{l}\text { Streptomyces sp. } \\
\text { NPS008187 }\end{array}$ & $\begin{array}{l}\text { Alaskan marine sediment } \\
\text { (Arctic Ocean) }\end{array}$ & $\begin{array}{l}\text { glyciapyrroles A (11), B (12) and C (13), } \\
\text { cyclo(leucyl-prolyl), cyclo(isoleucyl-prolyl), } \\
\text { cyclo(phenylalanyl-prolyl) }\end{array}$ & $\begin{array}{l}\text { pyrrolosesquiterpenes, } \\
\text { diketopiperazines }\end{array}$ & $\begin{array}{l}\text { Cytotoxic activity against colorectal } \\
\text { adenocarcinoma HT-29 } \\
\text { and melanoma } \\
\text { B16-F10 }\end{array}$ & [80] \\
\hline
\end{tabular}


Table 1. Cont.

\begin{tabular}{|c|c|c|c|c|c|}
\hline Species & $\begin{array}{l}\text { Collection Site } \\
\text { (Distribution) }\end{array}$ & Compound & Molecule Type & Bioactivity & Reference \\
\hline \multirow{5}{*}{$\begin{array}{l}\text { Pseudoalteromonas } \\
\text { haloplanktis TAC125 }\end{array}$} & \multirow{5}{*}{$\begin{array}{c}\text { French Antarctic station } \\
\text { Dumont d'Urville, Terre Adélie } \\
\text { (Antarctica) }\end{array}$} & $\begin{array}{l}\text { Plylum Proteobacteria } \\
\text { Class } \gamma \text {-Proteobacteria }\end{array}$ & & & \\
\hline & & methylamine & $\begin{array}{c}\text { Volatile Organic } \\
\text { Compounds (VOCs) }\end{array}$ & $\begin{array}{l}\text { Antimicrobial activity against } \\
\text { B. cepacia complex }\end{array}$ & [81] \\
\hline & & 4-hydroxybenzoic acid & benzoic acid derivative & $\begin{array}{l}\text { Antitumor activity against human } \\
\text { A459 lung adenocarcinoma cells }\end{array}$ & [82] \\
\hline & & $\begin{array}{c}\text { cyclo-(D-pipecolinyl-L-isoleucine), } \\
\text { cyclo-(L-prolyl-L-histidine), cyclo-(L-prolyl-L-alanine), } \\
\text { cyclo-(L-prolyl-L-tyrosine), cyclo-(L-prolyl-L-proline), } \\
\text { cyclo-(L-alanyl-L-isoleucine), } \\
\text { cyclo-(D-pipecolinyl-L-leucine), } \\
\text { cyclo-(L-pipecolinyl-L-phenylalanine), } \\
\text { L-valyl-L-leucyl-Lprolyl-L-valyl-L-prolyl-L-glutamine } \\
\text { and L-tyrosyl-L-valyl-L-prolyl-L-leucine }\end{array}$ & diketopiperazines & Antioxidant activity & [83] \\
\hline & & pentadecanal & long-chain fatty aldehyde & $\begin{array}{l}\text { Anti-biofilm activity against } \\
\text { Staphylococcus epidermidis }\end{array}$ & [84] \\
\hline Pseudomonas sp. & $\begin{array}{c}\text { Terranova Bay, Ross Sea } \\
\text { (Antarctica) }\end{array}$ & monoramnholipids & rhamnolipid & $\begin{array}{l}\text { Antimicrobial activity against } \\
\text { B. cepacia complex }\end{array}$ & [70] \\
\hline Psychrobacter & $\begin{array}{l}\text { Marine sediment from } \\
\text { Terranova Bay, Ross Sea } \\
\text { (Antarctica) }\end{array}$ & monoramnholipids & rhamnolipid & $\begin{array}{l}\text { Antimicrobial activity against } \\
\text { B. cepacia complex }\end{array}$ & [70] \\
\hline Aequorivita & $\begin{array}{l}\text { Marine sediments from } \\
\text { Edmonson Point (Antarctica) }\end{array}$ & $\begin{array}{c}\text { Plylum Bacteroidetes } \\
\text { Class Flavobacteriia } \\
\text { R-(+)-N-[15-methyl-3-(12-methyltridecanoyloxy)- } \\
\text { hexadecanoyl]glycine and methyl ester derivatives; }\end{array}$ & aminolipids & $\begin{array}{l}\text { Antimicrobial activity against } \\
\text { S. aureus }\end{array}$ & [85] \\
\hline Salegentibacter strain T436 & $\begin{array}{l}\text { Bottom section of a sea ice floe } \\
\text { (Arctic Ocean) }\end{array}$ & $\begin{array}{c}\text { 4-Hydroxy-3-nitrobenzoic acid, 4,6-Dinitroguiacol, } \\
\text { 4,5-Dinitro-3-methoxyphenol, } \\
\text { (4-Hydroxy-3-nitrophenyl)-acetic acid methyl ester, } \\
\text { (4-Hydroxy-3,5-dinitrophenyl)-acetic acid methyl ester, } \\
\text { (4-Hydroxy-3-nitrophenyl)-acetic acid, } \\
\text { (4-Hydroxy-3,5-dinitrophenyl)-acetic acid, } \\
\text { (4-Hydroxy-3,5-dinitrophenyl)-propionic acid methyl } \\
\text { ester, (4-Hydroxy-3-nitrophenyl)-propionic acid, } \\
\text { (4-Hydroxy-3,5-dinitrophenyl)-propionic acid, } \\
\text { 2-Chloro-3-(4-hydroxy-3,5-dinitrophenyl)-propionic acid } \\
\text { methyl ester, } \\
\text { 2-Hydroxy-3-(4-hydroxy-3-nitrophenyl)-propionic acid } \\
\text { methyl ester, 2-(4-Hydroxy-3-nitrophenyl)-ethanol, } \\
\text { 2-(4-Hydroxy-3,5-dinitrophenyl)-ethyl chloride, } \\
\text { 2-(4-Hydroxy-3,5-dinitrophenyl)-ethanol, 2-Nitro-4-(2 } \\
\text {-nitroethenyl)-phenol, 3,5-Dinitrogenistein, } \\
\text { 3-Nitrogenistein, 3-Nitro-1H-indole }\end{array}$ & aromatic nitro compounds & $\begin{array}{l}\text { Antimicrobial activity against } \\
\text { C. albicans, Paecilomyces variotii, } \\
\text { Penicillium notatumb, Mucor miehei Tü } \\
\text { 284, Magnaporthe grisea, Nematospora } \\
\text { coryli, Ustilago nuda, Bacillus brevis, } \\
\text { B. subtilis, M. luteus, Escherichia coli } \\
\text { K12b, Proteus vulgaris and } \\
\text { cytotoxic activities }\end{array}$ & {$[86,87]$} \\
\hline
\end{tabular}


Table 1. Cont.

\begin{tabular}{|c|c|c|c|c|c|}
\hline Species & $\begin{array}{l}\text { Collection Site } \\
\text { (Distribution) }\end{array}$ & Compound & Molecule Type & Bioactivity & Reference \\
\hline \multicolumn{6}{|c|}{$\begin{array}{l}\text { Plylum Firmicutes } \\
\text { Class Bacilli }\end{array}$} \\
\hline Bacillus sp. & $\begin{array}{l}\text { Sea mud } \\
\text { (Arctic Ocean) }\end{array}$ & mixirins $\mathrm{A}, \mathrm{B}$ and $\mathrm{C}$ & cyclopeptides & $\begin{array}{l}\text { Cytotoxic activity against } \\
\text { human colon tumor cells } \\
\text { (HCT-116) }\end{array}$ & [88] \\
\hline \multicolumn{6}{|c|}{$\begin{array}{c}\text { FUNGI } \\
\text { Plylum Ascomycota } \\
\text { Class Eurotiomycetes }\end{array}$} \\
\hline $\begin{array}{l}\text { Aspergillus protuberus } \\
\text { MUT } 3638\end{array}$ & $\begin{array}{l}\text { Sub-sea sediments, Barents Sea } \\
\text { (Arctic Ocean) }\end{array}$ & bisvertinolone & sorbicillonoid & $\begin{array}{c}\text { Antimicrobial activity against } \\
\text { S. aureus }\end{array}$ & [89] \\
\hline \multirow{2}{*}{ Penicillium sp. PR19N-1 } & \multirow{2}{*}{$\begin{array}{l}\text { Deep-sea sediment, Prydz Bay } \\
\text { (Antarctica) }\end{array}$} & $\begin{array}{c}\text { chlorinated eremophilane sesquiterpenes (14-17), } \\
\text { eremofortine C (18) }\end{array}$ & $\begin{array}{l}\text { chloro-eremophilane } \\
\text { sesquiterpenes }\end{array}$ & $\begin{array}{l}\text { Cytotoxic activity against HL-60 and } \\
\text { A549 cancer cell lines }\end{array}$ & [90] \\
\hline & & $\begin{array}{c}\text { eremophilane-type sesquiterpenes }(19-23,25,26), \\
\text { eremophilane-type lactam }(24,27)\end{array}$ & $\begin{array}{l}\text { eremophilane-type } \\
\text { sesquiterpenes }\end{array}$ & $\begin{array}{l}\text { Cytotoxic activity against HL-60 and } \\
\text { A549 cancer cell lines }\end{array}$ & [91] \\
\hline $\begin{array}{l}\text { Penicillium granulatum } \\
\text { MCCC 3A00475 }\end{array}$ & $\begin{array}{l}\text { Deep-sea sediment, Prydz Bay } \\
\text { (Antarctica) }\end{array}$ & $\begin{array}{l}\text { spirograterpene A (37), conidiogenone I ( } 38 \text { ) and } \\
\text { conidiogenone C (39) }\end{array}$ & $\begin{array}{l}\text { tetracyclic spiro-diterpene, } \\
\text { cyclopiane diterpenes }\end{array}$ & $\begin{array}{c}\text { Spirograterpene A: antiallergic effect } \\
\text { on immunoglobulin E } \\
\text { (IgE)-mediated rat mast } \\
\text { RBL-2H3 cells } \\
\end{array}$ & [92] \\
\hline $\begin{array}{l}\text { Penicillium sp. } \\
\quad \text { S-1-18 }\end{array}$ & Sea-bed sediments (Antarctica) & $\begin{array}{l}\text { butanolide, } \\
\text { guignarderemophilane F, xylarenone A (28) }\end{array}$ & $\begin{array}{l}\text { furanone derivative, } \\
\text { sesquiterpene }\end{array}$ & $\begin{array}{l}\text { Butanolide: inhibitory activity of } \\
\text { butanolide against tyrosine } \\
\text { phosphatase } 1 \mathrm{~B} ; \text {; xylarenone A: } \\
\text { antitumor activity against HeLa and } \\
\text { HepG2 cells and growth-inhibitory } \\
\text { effects against pathogenic microbes }\end{array}$ & {$[93,94]$} \\
\hline $\begin{array}{l}\text { Penicillium crustosum } \\
\quad \text { PRB-2 }\end{array}$ & $\begin{array}{l}\text { Deep-sea sediment, Prydz Bay } \\
\text { (Antarctica) }\end{array}$ & penilactones A and B & oxygenated polyketides & $\begin{array}{c}\text { Cytotoxic activity against HCT-8, } \\
\text { Bel-7402, BGC-823, A549 and A2780 } \\
\text { tumor cell lines }\end{array}$ & [95] \\
\hline \multicolumn{6}{|c|}{ Class Dothideomycetes } \\
\hline $\begin{array}{l}\text { Strain KF970 } \\
\text { (Lindgomycetaceae } \\
\text { family) }\end{array}$ & $\begin{array}{l}\text { Sea-water } \\
\text { (Arctic Ocean) }\end{array}$ & lindgomycin, ascosetin & polyketides & $\begin{array}{l}\text { Antimicrobial activity against } \\
\text { methicillin-resistant } S \text {. aureus }\end{array}$ & [96] \\
\hline \multicolumn{6}{|c|}{$\begin{array}{c}\text { ALGAE-ASSOCIATED MICROBES } \\
\text { Bacteria-Plylum Actinobacteria-Class Actinobacteria }\end{array}$} \\
\hline Nocardiopsis sp. $03 \mathrm{~N} 67$ & $\begin{array}{l}\text { Arctic seaweed } \\
\text { (Undaria pinnatifida) }\end{array}$ & cyclo-(L-Pro-L-Met) & diketopiperazine & $\begin{array}{l}\text { Anti-angiogenesis activity against } \\
\text { human umbilical vein endothelial } \\
\text { cells (HUVECs) }\end{array}$ & [97] \\
\hline
\end{tabular}


Table 1. Cont

\begin{tabular}{|c|c|c|c|c|c|}
\hline Species & $\begin{array}{l}\text { Collection Site } \\
\text { (Distribution) }\end{array}$ & Compound & Molecule Type & Bioactivity & Reference \\
\hline \multicolumn{6}{|c|}{$\begin{array}{c}\text { SPONGE-ASSOCIATED MICROBES } \\
\text { Bacteria-Plylum Bacteroidetes-Class Flavobacteriia }\end{array}$} \\
\hline Cellulophaga fucicola & Antarctic sea sponge & zeaxanthin (110), $\beta$-cryptoxanthin (111), $\beta$-carotene (112) & carotenoids & Antioxidant activity & [98] \\
\hline Zobellia laminarie & Antarctic sea sponge & $\begin{array}{c}\text { zeaxanthin (110), } \beta \text {-cryptoxanthin (111), } \beta \text {-carotene (112), } \\
\text { phytoene (113) }\end{array}$ & carotenoids & $\begin{array}{c}\text { Anti-UV and antioxidant activity and } \\
\text { phototoxicity profile in } \\
\text { murine fibroblasts }\end{array}$ & [99] \\
\hline Pseudomonas aeruginosa & $\begin{array}{l}\text { Isodictya setifera, } \\
\text { Ross Island (Antarctica) }\end{array}$ & $\begin{array}{l}\text { Bacteria-Plylum Proteobacteria-Class } \gamma \text {-Protec } \\
\text { cyclo-(L-Pro-L-Val)/cyclo-(L-Pro-L-Leu)/cyclo-(L-Pro-L-Ile)/ } \\
\text { cyclo-(L-Pro-L-Phe)/cyclo-(L-Pro-L-Tyr)/cyclo-(L-Pro-L-Met)/ } \\
\text { diketopiperazines, phenazine-1-carboxylic acid, } \\
\text { phenazine-1-carboxamide }\end{array}$ & $\begin{array}{l}\text { acteria } \\
\text { diketopiperazines, } \\
\text { phenazine alkaloids }\end{array}$ & $\begin{array}{l}\text { Antimicrobial activity against } \\
\text { B. subtilis, S. aureus and M. luteus }\end{array}$ & [65] \\
\hline $\begin{array}{l}\text { Pseudogymnoascus sp. } \\
\text { F09-T18-1 }\end{array}$ & $\begin{array}{l}\text { Antarctic sponge genus } \\
\text { Hymeniacidon, Fildes Bay, King } \\
\text { George Island (Antarctica) }\end{array}$ & pseudogymnoascin A, B, C, 3-nitroasterric acid & $\begin{array}{l}\text { nitroasterric acid } \\
\text { derivatives }\end{array}$ & $\begin{array}{l}\text { Inactive in antimicrobial activity } \\
\text { against P. aeruginosa, } \\
\text { Acinetobacter baumannii, E. coli, } \\
\text { S. aureus, a methicillin-sensitive } \\
\text { S. aureus and methicillin-resistant } \\
\text { S. aureus, C. albicans, } \\
\text { Aspergillus fumigatu }\end{array}$ & [100] \\
\hline \multicolumn{6}{|c|}{$\begin{array}{c}\text { CORAL-ASSOCIATED MICROBES } \\
\text { Fungi-Plylum Ascomycota-Class Eurotiomycetes }\end{array}$} \\
\hline Penicillium sp. SF-5995 & $\begin{array}{l}\text { Unidentified soft coral, Terra } \\
\text { Nova Bay (Antarctica) }\end{array}$ & methylpenicinoline & $\begin{array}{l}\text { pyrrolyl 4-quinoline } \\
\text { alkaloid }\end{array}$ & $\begin{array}{l}\text { Anti-inflammatory effect inhibiting } \\
\text { NF-kB and MAPK pathways in } \\
\text { lipopolysaccharide-induced } \\
\text { RAW264.7 macrophages and } \\
\text { BV2 microglia }\end{array}$ & [101] \\
\hline \multicolumn{6}{|c|}{$\begin{array}{c}\text { CNIDARIA } \\
\text { Plylum Cnidaria-Class Anthozoa }\end{array}$} \\
\hline Alcyonium antarcticum & Terra Nova Bay (Antarctica) & bulgarane sesquiterpene & sesquiterpene & $\begin{array}{l}\text { No bioactivity tested (antipredation } \\
\text { activity and ichthyotoxicity)* }\end{array}$ & [102] \\
\hline Alcyonium antarcticum & Weddell Sea (Antarctica) & alcyopterosins & $\begin{array}{c}\text { illudalane } \\
\text { sesquiterpenoids }\end{array}$ & $\begin{array}{c}\text { No bioactivity tested } \\
(\text { antipredation activity })^{*}\end{array}$ & [103] \\
\hline Alcyonium paessleri & $\begin{array}{l}\text { South Georgia Islands } \\
\text { (Antarctica) }\end{array}$ & alcyopterosin A (29), C (30), E (31), H (32) & $\begin{array}{l}\text { illudalane } \\
\text { sesquiterpenoids }\end{array}$ & $\begin{array}{l}\text { Cytotoxic activity against Hep-2 } \\
\text { (human larynx carcinoma) and HT-29 } \\
\text { (human colon carcinoma) cell lines }\end{array}$ & [104] \\
\hline Alcyonium paessleri & $\begin{array}{l}\text { South Georgia Islands } \\
\text { (Antarctica) }\end{array}$ & paesslerins A (33), B (34) & esquiterpenoids & $\begin{array}{l}\text { Cytotoxic activity against human } \\
\text { tumor cell lines }\end{array}$ & [105] \\
\hline Anthomastus bathyproctus & $\begin{array}{l}\text { Deception Island, South } \\
\text { Shetland Islands (Antarctica) }\end{array}$ & $\begin{array}{l}\text { conjugated cholestane, ergostane and 24-norcholestane } \\
\text { steroids (79-82) }\end{array}$ & steroids & $\begin{array}{l}\text { Cytotoxic activity against three } \\
\text { human tumor cell lines. }\end{array}$ & [106] \\
\hline
\end{tabular}


Table 1. Cont

\begin{tabular}{|c|c|c|c|c|c|}
\hline Species & $\begin{array}{l}\text { Collection Site } \\
\text { (Distribution) }\end{array}$ & Compound & Molecule Type & Bioactivity & Reference \\
\hline Anthoptilum grandiflorum & $\begin{array}{l}\text { Burdwood Bank, Scotia Arc } \\
\text { (Antarctica) }\end{array}$ & bathyptilone A (48), B, C, enbepeanone A & $\begin{array}{l}\text { briarane diterpenes, } \\
\text { trinorditerpene }\end{array}$ & $\begin{array}{l}\text { Bathyptilone A: cytotoxic activity } \\
\text { against the neurogenic mammalian } \\
\text { cell line Ntera-2 }\end{array}$ & [107] \\
\hline Dasystenella acanthina & $\begin{array}{l}\text { Kapp Norvegia, Eastern } \\
\text { Weddell Sea (Antarctica) }\end{array}$ & 7 polyoxygenated steroids $(\mathbf{8 3}-89)$ & steroids & $\begin{array}{l}\text { Growth inhibition of several human } \\
\text { tumor cell lines LN-caP and K-562 }\end{array}$ & [108] \\
\hline Gersemia fruticosa & White Sea (circumpolar Arctic) & 6 polyoxygenated sterols (90-95) & sterols & $\begin{array}{l}\text { Cytotoxic activity against human } \\
\text { erythroleukemia K-562 cells, HL-60 } \\
\text { and P388 }\end{array}$ & [109] \\
\hline Gersemia fruticosa & White Sea (circumpolar Arctic) & 9,11-secosterol (96) & sterol & $\begin{array}{l}\text { Cytotoxic activity against human } \\
\text { leukemia K562, cervical cancer HeLa } \\
\text { and Ehrlich ascites tumor cells }\end{array}$ & [110] \\
\hline Gersemia fruticosa & $\begin{array}{l}\text { Alaskan Beaufort Sea } \\
\text { (Arctic Ocean) }\end{array}$ & $\begin{array}{l}\text { gersemiols A-C, } \\
\text { eunicellol A (40) }\end{array}$ & diterpenoids & $\begin{array}{c}\text { Eunicellol A: antimicrobial activity } \\
\text { against MRSA-methicillin resistant } \\
\text { S. aureus }\end{array}$ & [111] \\
\hline Plumarella delicatissima & $\begin{array}{l}\text { Plateau of Fascination, Falkland } \\
\text { Islands (Antarctica) }\end{array}$ & $\begin{array}{l}\text { keikipukalides A-E (41-45), } \\
\text { pukalide aldehyde (46), norditerpenoid ineleganolide (47) }\end{array}$ & diterpenes, diterpenoid & $\begin{array}{c}\text { Cytotoxic activity against } \\
\text { leishmaniasis causing a parasite, } \\
\text { Leishmania donovani, with no } \\
\text { cytotoxicity against the } \\
\text { mammalian host }\end{array}$ & [112] \\
\hline Undescribed soft coral & Scotia Arc (Antarctica) & shagenes A (35), B (36) & sesquiterpenoids & $\begin{array}{l}\text { Cytotoxic activity against } \\
\text { leishmaniasis causing a parasite, } \\
\text { L. donovani, with no cytotoxicity } \\
\text { against the mammalian host }\end{array}$ & [113] \\
\hline \multicolumn{6}{|c|}{$\begin{array}{c}\text { BRYOZOA } \\
\text { Plylum Bryozoa-Class Gymnolaemata }\end{array}$} \\
\hline Tegella cf. spitzbergensis & $\begin{array}{l}\text { Bear Island } \\
\text { (Arctic Ocean) }\end{array}$ & ent-eusynstyelamide B, eusynstyelamides D-F & $\begin{array}{l}\text { brominated } \\
\text { tryptophan-derived }\end{array}$ & $\begin{array}{c}\text { Antimicrobial activity against } \\
\text { bacteria; weak cytotoxicity against } \\
\text { the human melanoma } \\
\text { A2058 cell line }\end{array}$ & [114] \\
\hline Dendrobeania murrayana & $\begin{array}{l}\text { Vesterålsfjorden, Northern } \\
\text { Norway (Arctic Ocean) }\end{array}$ & dendrobeaniamine A & guanidine alkaloid & $\begin{array}{l}\text { Tested but inactive for cytotoxic, } \\
\text { antimicrobial, anti-inflammatory or } \\
\text { antioxidant activities }\end{array}$ & [115] \\
\hline Alcyonidium gelatinosum & $\begin{array}{l}\text { Hopenbanken, Svalbard } \\
\quad \text { (Arctic Ocean) }\end{array}$ & ponasterone $\mathrm{A}$ and $\mathrm{F}$ & ecdysteroids & $\begin{array}{l}\text { Tested but inactive for cytotoxic, } \\
\text { antimicrobial, estrogen receptor } \\
\text { agonist activities }\end{array}$ & [52] \\
\hline
\end{tabular}


Table 1. Cont

\begin{tabular}{|c|c|c|c|c|c|}
\hline Species & $\begin{array}{l}\text { Collection Site } \\
\text { (Distribution) }\end{array}$ & Compound & Molecule Type & Bioactivity & Reference \\
\hline \multicolumn{6}{|c|}{$\begin{array}{c}\text { MOLLUSCA } \\
\text { Plylum Mollusca-Class Gasteropoda }\end{array}$} \\
\hline Austrodoris kerguelenensis & $\begin{array}{l}\text { Anvers Island (Circumpolar } \\
\text { Antarctica) }\end{array}$ & palmadorin A (49), B (50), D (51), M (52), N (53), O (54) & $\begin{array}{l}\text { diterpenoid } \\
\text { glyceride esters }\end{array}$ & $\begin{array}{c}\text { Inhibition of human erythroleukemia } \\
\text { (HEL) cells; Palmadorin M inhibits } \\
\text { Jak2, STAT5, and Erk1/2 activation in } \\
\text { HEL cells }\end{array}$ & [116] \\
\hline \multicolumn{6}{|c|}{$\begin{array}{l}\text { ECHINODERMATA } \\
\text { Plylum Echinodermata- } \\
\text { Class Holothuroidea }\end{array}$} \\
\hline Kolga hyalina & $\begin{array}{c}\text { Deep sea, } \\
\text { Amundsen Basin (Arctic Ocean) }\end{array}$ & holothurinoside B, kolgaosides A (120), B (121) & $\begin{array}{l}\text { triterpene holostane } \\
\text { nonsulfated pentaosides }\end{array}$ & $\begin{array}{l}\text { Kolgaosides A-B: hemolytic activity } \\
\text { against mouse erythrocytes } \\
\text { and inhibition } \\
\text { against Ehrlich ascite } \\
\text { carcinoma cells }\end{array}$ & [117] \\
\hline Staurocucumis liouvillei & $\begin{array}{l}\text { South Georgia Islands } \\
\text { (Antarctica) }\end{array}$ & liouvillosides A (118), B (119) & $\begin{array}{l}\text { trisulfated triterpene } \\
\text { glycosides }\end{array}$ & $\begin{array}{c}\text { Activity against herpes simplex virus } \\
\text { type } 1 \\
\text { (HSV-1) }\end{array}$ & [118] \\
\hline \multicolumn{6}{|c|}{ Class Astheroidea } \\
\hline Asterias microdiscus & $\begin{array}{l}\text { Chukchi Sea } \\
\text { (Arctic Ocean) }\end{array}$ & polyhydroxylated steroids A-F & steroids & No activity tested * & [119] \\
\hline \multicolumn{6}{|c|}{ Class Ophiuroidea } \\
\hline Ophiosparte gigas & $\begin{array}{l}\text { Ross Sea } \\
\text { (Antarctica) }\end{array}$ & $\begin{array}{l}\text { cholest-5-ene-2 } \alpha, 3 \alpha, 4 \beta, 21 \text {-tetrao1-3,21-disulphate (102), } \\
\text { cholest-5-ene-2} \beta, 3 \alpha, 21 \text {-triol-2,21-disulphate (103) }\end{array}$ & $\begin{array}{c}\text { disulfated } \\
\text { polyhydroxysteroids }\end{array}$ & $\begin{array}{c}\text { cholest-5-ene-2 } \alpha, 3 \alpha, 4 \beta, 21 \text {-tetrao1-3, } \\
\text { 21-disulphate: cytotoxic activity; } \\
\text { cholest-5-ene-2 } \beta, 3 \alpha, \\
\text { 21-triol-2,21-disulphate: } \\
\text { cytoprotective activity against HIV-1 }\end{array}$ & [120] \\
\hline Astrotoma agassizii & Antarctica & disulfated polyhydroxysteroids (104-106) & $\begin{array}{c}\text { disulfated } \\
\text { polyhydroxysteroids }\end{array}$ & $\begin{array}{l}\text { Activity against one DNA (HSV-2) } \\
\text { and two RNA (PV-3, JV) viruses }\end{array}$ & [121] \\
\hline \multicolumn{6}{|c|}{$\begin{array}{c}\text { SPONGES } \\
\text { Plylum Porifera } \\
\text { Class Demospongiae }\end{array}$} \\
\hline Crella sp. & $\begin{array}{l}\text { Norsel Point, } \\
\text { Amsler Island (Antarctica) }\end{array}$ & norselic acid A (97), B (98), C (99), D (100), E (101) & oxidized steroids & $\begin{array}{l}\text { Norselic acid A: activity against } \\
\text { MRSA, methicillin-sensitive S. aureus } \\
\text { (MSSA) and vancomycin-resistant } \\
\text { Enterococci faecium (VREF) and C. } \\
\text { albicans. All norselic acids were } \\
\text { active against leishmaniasis }\end{array}$ & [122] \\
\hline
\end{tabular}


Table 1. Cont

\begin{tabular}{|c|c|c|c|c|c|}
\hline Species & $\begin{array}{l}\text { Collection Site } \\
\text { (Distribution) }\end{array}$ & Compound & Molecule Type & Bioactivity & Reference \\
\hline \multirow{3}{*}{ Dendrilla antarctica } & \multirow{3}{*}{ Anvers Island (Antarctica) } & $\begin{array}{l}\text { aplysulphurin (55), membranoid A (56), B (57), C (58), D } \\
\text { (59), E (60), G (61),H (62) }\end{array}$ & oxidized diterpenoids & $\begin{array}{l}\text { Aplysulphurin: activity against } C \text {. } \\
\text { albicans, and Gram-negative } \\
\text { antibiotic activity against } S \text {. aureus } \\
\text { and } E \text {. coli; membranoids: activity } \\
\text { against the leishmaniasis }\end{array}$ & {$[123,124]$} \\
\hline & & $\begin{array}{c}\text { darwinolide (63), tetrahydroaplysulphurin-1 (65), } \\
\text { membranolide (66), glaciolides (67-68), cadlinolide C (69), } \\
\text { dendrillin A (70), B (71), C (72), D (73) and semisynthetic } \\
\text { derivatives (74-76) }\end{array}$ & oxidized diterpenoids & $\begin{array}{l}\text { Darwinolide: selectivity against the } \\
\text { biofilm phase of MRSA compared to } \\
\text { the planktonic phase; membranolide: } \\
\text { activity against MRSA; dendrillin B: } \\
\text { activity against L. donovani; } 76 \text {, } \\
\text { activity against Plasmodium falciparum }\end{array}$ & {$[125,126]$} \\
\hline & & 9-11-dihydrogracilin A (64) & oxidized diterpenoid & $\begin{array}{c}\text { Immuno-modulatory and } \\
\text { anti-inflammatory activity in human } \\
\text { cell lines }\end{array}$ & [127] \\
\hline Geodia baretti & $\begin{array}{l}\text { North Sea off the coast of } \\
\text { Sweden and the northern coast } \\
\text { of Iceland (Arctic Ocean) }\end{array}$ & barettin and the geobarrettins & $\begin{array}{l}\text { diketopiperazine (likely } \\
\text { produced by a symbiont) }\end{array}$ & $\begin{array}{l}\text { Moderate antioxidant and } \\
\text { anti-inflammatory activities }\end{array}$ & $\begin{array}{c}{[53]} \\
{[128]} \\
{[129]}\end{array}$ \\
\hline Haliclona viscosa & $\begin{array}{l}\text { Svalbard Archipelago (Arctic } \\
\text { Ocean) }\end{array}$ & $\begin{array}{l}\text { viscosamine } \\
\text { viscosaline }\end{array}$ & $\begin{array}{l}\text { 3-alkyl pyridinium } \\
\text { alkaloids }\end{array}$ & $\begin{array}{l}\text { Antibiotic activity against four } \\
\text { separate sympatric bacterial strains }\end{array}$ & $\begin{array}{l}{[130]} \\
{[131]}\end{array}$ \\
\hline Kirkpatrickia variolosa & Antarctica & variolins A-D (B most active) & pyridopyrrolopyrimidine & $\begin{array}{l}\text { Cytotoxic activity against P388 } \\
\text { murine leukemia cell line }\end{array}$ & $\begin{array}{l}132] \\
{[133]}\end{array}$ \\
\hline \multirow{3}{*}{ Latrunculia sp. } & \multirow[t]{2}{*}{$\begin{array}{l}\text { Aleutian Islands, Alaska (also } \\
\text { found in Antarctic specimens) }\end{array}$} & \multirow[t]{2}{*}{ discorhabdins A, C, R, dihydrodiscorhabdin B } & \multirow[t]{2}{*}{$\begin{array}{c}\text { spirocyclic } \\
\text { imino-quinones }\end{array}$} & $\begin{array}{l}\text { Anti-HCV (Hepatitis C virus) activity, } \\
\text { antimalarial activity and selective } \\
\text { antimicrobial activity against MRSA, } \\
\text { Mycobacterium intracellulare and } \\
\text { M. tuberculosis. }\end{array}$ & \multirow[t]{2}{*}{ [134] } \\
\hline & & & & $\begin{array}{c}\text { Antiprotozoal activity in vitro } \\
(\text { P. falciparum })\end{array}$ & \\
\hline & Weddell Sea (Antarctica) & tsitsikammamines & pyrroloiminoquinones & $\begin{array}{c}\text { Anticancer and } \\
\text { cytotoxic activities }\end{array}$ & [57] \\
\hline Lyssodendoryx flabellata & Terra Nova Bay (Antarctica) & terpioside & glycosphingolipid & $\begin{array}{l}\text { Inhibition effect in mixed lymphocyte } \\
\text { reactions on human cells }\end{array}$ & [135] \\
\hline Mycale acerata & Terra Nova Bay (Antarctica) & mycalol & alkyl glyceryl ether lipid & $\begin{array}{l}\text { Activity against human thyroid } \\
\text { carcinoma cells }\end{array}$ & [136] \\
\hline
\end{tabular}


Table 1. Cont.

\begin{tabular}{|c|c|c|c|c|c|}
\hline Species & $\begin{array}{l}\text { Collection Site } \\
\text { (Distribution) }\end{array}$ & Compound & Molecule Type & Bioactivity & Reference \\
\hline Plakortis simplex & $\begin{array}{l}\text { Sula Ridge Reef, } \\
\text { Norwegian Shelf } \\
\text { (sub Arctic) }\end{array}$ & $\begin{array}{l}\text { methyl } \\
\text { 2-((3R,6S)-4,6-diethyl-6-hexyl-3,6-dihydro-1,2-dioxin- } \\
\text { 3-yl)acetate }\end{array}$ & $\begin{array}{l}\text { cyclic peroxide } \\
\text { (fatty acids) }\end{array}$ & $\begin{array}{l}\text { Selectively inhibited proliferation in } \\
\text { gastric cancer (GXF 251L), non-small } \\
\text { cell lung cancer (LXFL 529L) and } \\
\text { melanoma (MEXF 462NL) cell lines. }\end{array}$ & [137] \\
\hline \multirow[t]{2}{*}{ Polymastia boletiformis } & \multirow[t]{2}{*}{$\begin{array}{l}\text { Norwegian coast, Western Irish } \\
\text { Coast (sub Arctic) }\end{array}$} & \multirow[t]{2}{*}{ polymastiamide A (117), B, C, D, E, F } & \multirow[t]{2}{*}{$\begin{array}{l}\text { sulfated steroid-amino } \\
\text { acid conjugates }\end{array}$} & $\begin{array}{c}\text { Polymastiamide A: antifungal } \\
\text { activity against plant pathogens } \\
\text { Cladosporium cucumerinum and } \\
\text { Pythium ultimum and human yeast } \\
\text { pathogen C. albicans }\end{array}$ & [138] \\
\hline & & & & $\begin{array}{l}\text { Polymastiamide A: antibacterial } \\
\text { activity against } S \text {. aureus }\end{array}$ & $\begin{array}{l}{[139]} \\
{[140]}\end{array}$ \\
\hline Stryphus fortis & $\begin{array}{l}\text { Spitsbergen, Svalbard, (Arctic } \\
\text { Ocean) }\end{array}$ & ianthelline & bromotyrosine derivative & $\begin{array}{l}\text { Antitumor properties against several } \\
\text { malignant cell lines and inhibition of } \\
\text { PK activity }\end{array}$ & [141] \\
\hline Suberites sp. & $\begin{array}{l}\text { King George Isalnd, McMurdo } \\
\text { Sound (Antarctica) }\end{array}$ & suberitenones A (77), B (78) & oxidized sesterterpenoids & $\begin{array}{l}\text { Inhibition of the cholesteryl ester } \\
\text { transfer protein (CETP) }\end{array}$ & [142] \\
\hline & & $\begin{array}{c}\text { TUNICATES } \\
\text { Plylum Chordata } \\
\text { Class Ascidiacea }\end{array}$ & & & \\
\hline Aplidium meridianum & $\begin{array}{l}\text { South Georgia Islands } \\
\text { (Antarctica) }\end{array}$ & meridianins & $\begin{array}{l}\text { brominated } \\
\text { 3-(2-aminopyrimidine) } \\
\text { indoles }\end{array}$ & $\begin{array}{l}\text { Prevention of cell proliferation and } \\
\text { induction of cell apoptosis. Inhibition } \\
\text { of CDKs, GSK-3, PKA and other } \\
\text { kinases in the low micromolar range }\end{array}$ & [143] \\
\hline Aplidium sp. & Ross Sea (Antarctica) & rossinones A (122), B (123) & meroterpenoids & $\begin{array}{l}\text { Antiproliferative activity against } \\
\text { several cell lines. Antiviral activity } \\
\text { against the DNA virus HSV-1 as well } \\
\text { as antibacterial and antifungal } \\
\text { activity against } \text { B. subtilis and } \\
\text { Trichophyton mentagrophytes }\end{array}$ & [144] \\
\hline Clavelina lepadiformis & Bergen, Norway & lepadins & $\begin{array}{l}\text { decahydroquinoline } \\
\text { alkaloid }\end{array}$ & $\begin{array}{c}\text { Lepadin A: anti-cancer activity } \\
\text { against leukemia P388, breast cancer } \\
\text { (MCF7), glioblastoma/astrocytoma } \\
\text { (U373), ovarian (HEY), colon (LoVo) } \\
\text { and lung (A549) }\end{array}$ & $\begin{array}{l}{[145]} \\
{[146]}\end{array}$ \\
\hline \multirow{2}{*}{ Synoicum adareanum } & \multirow{2}{*}{ Anvers Island (Antarctica) } & palmerolides A-G & $\begin{array}{l}\text { enamide-bearing } \\
\text { macrolides }\end{array}$ & $\begin{array}{l}\text { Palmerolide A: Activity against } \\
\text { melanoma (UACC-62 LC50), by } \\
\text { inhibition of vacuolar ATPase- }\end{array}$ & $\begin{array}{l}{[147]} \\
{[148]}\end{array}$ \\
\hline & & $\begin{array}{c}\text { hyousterones A (107), B, C (108), D, } \\
\text { abeohyousterone (109) }\end{array}$ & ecdysteroids & Activity against colon cancer cells & [149] \\
\hline
\end{tabular}


Table 1. Cont.

\begin{tabular}{|c|c|c|c|c|c|}
\hline Species & $\begin{array}{l}\text { Collection Site } \\
\text { (Distribution) }\end{array}$ & Compound & Molecule Type & Bioactivity & Reference \\
\hline \multirow[t]{2}{*}{ Synoicum pulmonaria } & \multirow[t]{2}{*}{$\begin{array}{l}\text { Tromso, Northern Norway } \\
\text { (Arctic Ocean) }\end{array}$} & synoxazolidinones A-C & $\begin{array}{l}\text { brominated guanidinium } \\
\text { oxazolidinones }\end{array}$ & $\begin{array}{l}\text { Antibacterial activity against MSSA, } \\
\text { MRSA and } \\
\text { Corynebacterium glutamicum as well as } \\
\text { antifungal properties against } \\
\text { Saccharomyces cerevisiae. } \\
\text { Active against human melanoma } \\
\text { (A2058), breast adenocarcinoma } \\
\text { (MCF-7) and colon carcinoma (HT-29) } \\
\text { cell line, with noted cytoxicity }\end{array}$ & [150] \\
\hline & & pulmonarins A, B & $\begin{array}{c}\text { brominated } \\
\text { methoxybenzoylesters } \\
\text { bearing quaternary } \\
\text { ammonium mioeties }\end{array}$ & $\begin{array}{l}\text { Acetylcholinesterase inhibitory } \\
\text { activity and weak antibacterial } \\
\text { activity against } \text { C. glutamicum }\end{array}$ & [152] \\
\hline \multicolumn{6}{|c|}{$\begin{array}{l}\text { MACROALGAE } \\
\text { Plylum Rhodophyta } \\
\text { Class Florideophyceae }\end{array}$} \\
\hline $\begin{array}{l}\text { Delisea fimbriata and } \\
\quad \text { pulchra }\end{array}$ & Anvers Island (Antarctica) & fimbrolides and analogues & $\begin{array}{l}\text { polyhalogenated } \\
\text { furanones }\end{array}$ & $\begin{array}{c}\text { Antimicrobial activity against } S \text {. } \\
\text { aureus, E. coli, C. albicans and } \\
\text { Streptococcus sp. }\end{array}$ & [153] \\
\hline Plocamium cartilagineum & Anvers Island (Antarctica) & $\begin{array}{l}\text { oregonene (1) and similar compounds (2-4), anverenes A } \\
\text { (5), B (6), C (7), D (8), E (9) }\end{array}$ & $\begin{array}{c}\text { polyhalogenated } \\
\text { monoterpenes }\end{array}$ & $\begin{array}{l}\text { Cytotoxic activity against cervical } \\
\text { cancer cells }\end{array}$ & [154] \\
\hline \multicolumn{6}{|c|}{$\begin{array}{ll}\text { Plylum Ochrophyta } \\
\text { Class Phaeophyceae }\end{array}$} \\
\hline Desmarestia menziesii & Anvers Island (Antarctica) & Menzoquinone (124) & terpenoid-quinone & $\begin{array}{c}\text { Antimicrobial activity against MRSA, } \\
\text { MSSA, VREF }\end{array}$ & [155] \\
\hline
\end{tabular}

* Natural compounds with no bioactivity tested. 


\subsection{Marine chemical diversity in Polar Regions}

In the Antarctic and Arctic marine environment, a huge reservoir of microbial biodiversity has been recognized as promising for the isolation of new antimicrobial metabolites [85,156-159]. Among marine bacteria, Pseudoalteromonas haloplanktis TAC125 is a potential untapped source of biologically active natural products [160]. This cold-adapted bacterium produces valuable bioactive secondary metabolites, such as anti-biofilm metabolites [160], antibiotics such as methylamine, a volatile compound active against Burkholderia cepacia complex strains [81] and anticancer compounds [82]. The biotechnological potential of P. haloplanktis TAC125 is related to its genus Pseudoalteromonas, ubiquitously distributed in almost all marine habitats. The recent reconstruction of the largest Pseudoalteromonas pangenome allowed the identification of Pseudoalteromonas genes for cold adaptation and the production of secondary metabolites, among others [161]. Other Antarctic strains belonging to the same genus have proven useful for cosmetic application, including Antarcticine ${ }^{\circledR}$ launched by LIPOTEC as an anti-aging product obtained from extracts of marine Pseudoalteromonas antarctica [162], and SeaCode ${ }^{\circledR}$, a mixture of EPS and other glucidic exopolymers produced by biotechnological fermentation of a Pseudoalteromonas sp. isolated in Antarctic waters [163].

On the macroscopic realm, several new natural products have been isolated from marine polar biota, some yielding encouraging properties for biotech discovery [6]. The Arctic bryozoan Dendrobeania murrayana revealed the presence of the guanidine alkaloid, dendrobeaniamine A, which was inactive in cytotoxicity, antimicrobial, anti-inflammatory and antioxidant assays [115]. The permethylated hexapeptide friomaramide is a potent inhibitor of liver-stage infection by Plasmodium falciparum [164]. Among all marine natural products coming from the polar seas, we will focus in this review on terpenoids and their derivatives (included in Table 1), because they represent one of the most important classes of bioactive molecules commonly found in polar organisms.

\subsection{Marine Polar Terpenoids}

In marine environments, terpenes, terpenoids and their derivatives display an array of diverse chemical structures, with promising biological activities [165-168]. Terpenes are hydrocarbons that represent a large family of natural compounds, which include primary and secondary metabolites metaphorically biosynthesized from five carbon isoprene units.

Terpenoids, which are sometimes called isoprenoids, are derivatives or modified terpenes. Although sometimes used interchangeably with "terpenes," terpenoids are often polycyclic structures where methyl groups have been moved or removed, and oxygen-containing functional groups have been added. About $60 \%$ of known natural products are terpenoids [169].

Modification of the isoprene unit structures leads to a wide structural diversity of derivatives showing diverse bioactivities. Terpenes and terpenoids are often classified by the number of isoprene units added to the parent terpene, and divided into biogenetic subclasses, e.g., monoterpenes, sesquiterpenes, diterpenes, sesterterpenes, triterpenes and tetraterpenes, containing two, three, four, five, six and seven isoprene units, respectively. The triterpenes include sterols and steroids and their derivatives conjugated to other functional group while the tetraterpenes include carotenoids. There are also compounds that contain terpene fragments, such as prenylated polyketides (meroterpenes, indole alkaloids).

Their biosynthesis was described in 1953, by Leopold Ružička as the $\mathrm{C}_{5}$ rule or biogenetic isoprene rule, reporting the linking of isoprene units "head to tail" to form chains [170]. There are two metabolic pathways that create terpenoids (Figure 1): (a) the mevalonic acid or mevalonate pathway (MVA pathway), which also produces cholesterol and occurs in the cytoplasm of most organisms (e.g., bacteria, archaea, fungi, plants, animals), except green algae; and (b) the 2-C-methyl-D-erythritol 4-phosphate/1-deoxy-D-xylulose 5-phosphate pathway (MEP/DOXP pathway), also known as non-mevalonate pathway, takes place in plastids of plants and green algae, in apicomplexan protozoa and in many bacteria [171]. From these two pathways isopentenyl diphosphate (IPP) and its isomer dimethylallyl diphosphate (DMAPP) are derived, which are sequentially elongated by 
prenyltransferases to geranyl diphosphate $\left(C_{10}\right)$, farnesyl diphosphate $\left(C_{15}\right)$ and geranylgeranyl diphosphate $\left(C_{20}\right)$ (Figure 1$)$. These acyclic intermediates are then transformed by terpenoid synthases into monoterpenes, sesquiterpenes and diterpenes and further modifications produce triterpenes and tetraterpenes [171].

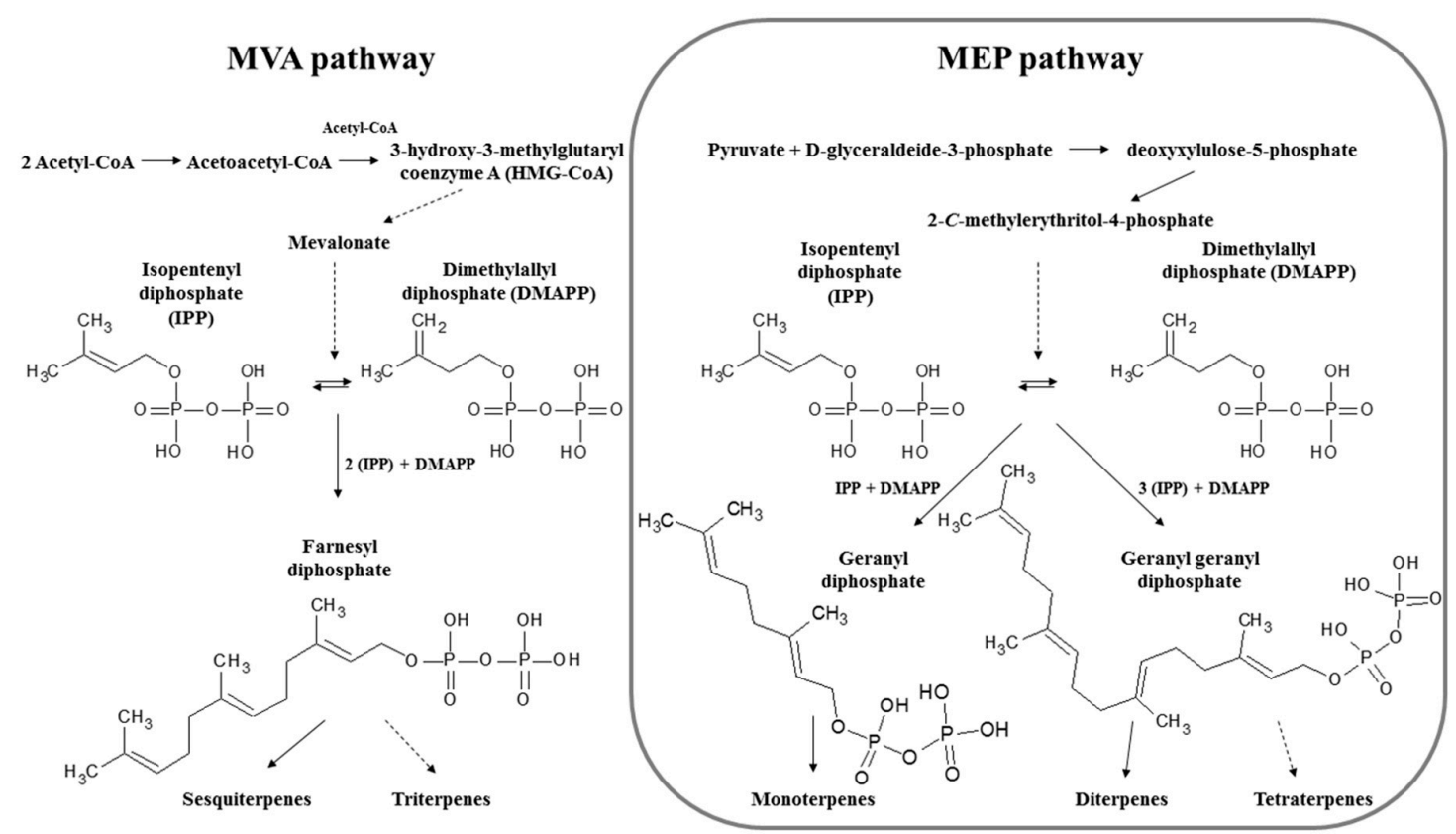

Figure 1. Schematic representation of isoprenoid biosynthesis by mevalonate pathway (MVA pathway) starting from two molecules of Acetyl-CoA and non-mevalonate pathway (MEP pathway) starting from pyruvate and glyceraldeide-3-phosphate. Adapted from [171].

Marine organisms are prolific producers of terpenes and terpenoids. Particularly in cnidarians (corals), mollusks and sponges, these types of compounds are well represented among reported natural products. In ascidians and echinoderms, the proportion of terpene and terpenoid molecules reported to date is lower but they are still relatively common. In total, terpenoids are the most frequently reported natural product class from the Antarctic, displaying a large degree of structural diversity and bioactivity [172]. In the following paragraphs, we will describe some aspects of the biotechnological potential of terpene and terpenoid compounds from polar latitudes.

\subsubsection{Monoterpenes and Monoterpenoids}

Monoterpenes are comprised of two isoprene units that result from a single condensation between DMAPP and IPP to yield a 10-carbon molecule, which is often further modified (Figure 1). Polyhalogenated monoterpenes are commonly produced by red algae inhabiting the shallow waters of the polar regions. These metabolites are often found in high abundance and can be either linear or cyclic. Like many natural products found in other phyla, the ecological function of these halogenated secondary metabolites is thought to be multi-faceted. The most commonly assumed role is that of defense, conveying deterrence against herbivory and resistance to detrimental fouling species [173]. These compounds may also be used offensively, possibly providing allelopathic competitive advantages to the producers, while deleteriously affecting potential competitors for space and resources [155,174-176].

Likely owing to their defensive and offensive ecological functions in nature, previous investigations into the therapeutic potential of halogenated metabolites in red seaweeds from other regions have yielded a plethora of relevant biological activities, ranging from antimicrobial to perhaps most notably their antitumor properties $[155,174-177]$. Similarly, a recent chemical investigation of what is generally considered to be an Antarctic subspecies of the red alga Plocamium cartilagineum collected from around 
Anvers Island along the Western Antarctic Peninsula yielded several polyhalogenated monoterpenes (1-9) including anverenes A-E (Figure 2), which displayed cytotoxicity in the low micromolar range (1-13 $\mu \mathrm{M})$ against a cervical cancer cell line (HeLa) [154].<smiles>C[C@@](Cl)(/C=C/Br)[C@H](Cl)/C=C/C(Cl)(CCl)CBr</smiles>

Oregonene A (1)<smiles>CC(Cl)(/C=C/Cl)[C@H](Cl)/C=C/C(Cl)(CCl)CBr</smiles>

2<smiles>CC(Cl)(/C=C/C(Cl)[C@](C)(Cl)/C=C/Cl)CBr</smiles>

3<smiles>CC(Cl)(/C=C/C(Cl)C(C)(Cl)/C=C/Br)CBr</smiles>

4<smiles>CC(Cl)(/C=C/Br)C(Br)C[C@@H](Cl)C(C)(C)Br</smiles>

Anverene A (5)

Anverene B (6)<smiles>CC(=CCC(Cl)C(C)(C)Br)C(Cl)C(Br)Br</smiles>

Anverene C (7)<smiles>CC(=CC(Cl)Cl)C(Br)CC(Br)C(C)(C)Cl</smiles>

Anverene D (8)

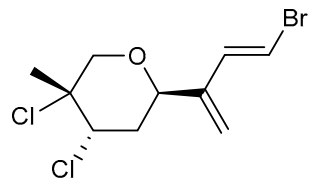

Anverene E (9)

Figure 2. Structures of monoterpenoid compounds, (1-9) oregonene A and anverenes A-E from Plocamium cartilagineum.

\subsubsection{Sesquiterpenes and Sesquiterpenoids}

Sesquiterpenes comprise "one and a half monoterpenes" (sesqui- prefix means one and a half), thus, three isoprene units. They may be acyclic or contain rings, including many unique combinations. As in other terpenes, biochemical modifications such as oxidation or rearrangement produce the related sesquiterpenoids $[169,171]$. Sesquiterpenes and sesquiterpenoids are an important class of natural products with a wide range of biological activities as semiochemicals, e.g., defensive agents or pheromones, and commonly found in terrestrial organisms (e.g., plants, fungi and insects). Their occurrence in the marine environment is quite remarkable, with several ecological and pharmacological bioactivities described [178]. Therefore, marine sesquiterpenes and derivatives represent important candidates for natural products in drug discovery [166,179-181].

Streptomyces sp. SCO-736, isolated from an Antarctic marine sediment, was found to produce antartin (10) a tricyclic zizaane-type sesquiterpene with an unusual phenyl group (Figure 3) [79]. Tricyclic sesquiterpenes are an important class of marine natural products characterized by structural diversity often unprecedented when compared to terrestrial metabolites. They often display interesting biological activity, such as antifouling, cytotoxic, antibiotic, antifungal, antiparasitic and anti-inflammatory activities [182]. Antartin displays moderate cytotoxicity against a wide range of cancer cell lines, A549, H1299 and U87 cell lines, by causing cell cycle arrest at the G1 phase [79].

Streptomyces sp. NPS008187, isolated from a marine sediment in Alaska, produces three pyrrolosesquiterpenes, glyciapyrroles A (11), B (12) and C (13), along with the known diketopiperazines cyclo(leucyl-prolyl), cyclo(isoleucyl-prolyl) and cyclo(phenylalanyl-prolyl) (Figure 3). Glaciapyrrole A displays moderate antitumor activity against both colorectal adenocarcinoma HT-29 and melanoma B16-F10 tumor cell growth [80].

Although terpenoid substructures are often mixed with aromatic ring systems of various types (e.g., phenols, quinones, coumarines and flavonoids), they are rarely found in combination with pyrroles; there are only a few cases: pyrrolostatin, isolated from a Brazilian soil Actinobacteria Streptomyces chrestomyceticus EC40 [183], and two pyrrolosesquiterpenes isolated from soil actinomycete Streptomyces sp. Hd7-21 [184]. 

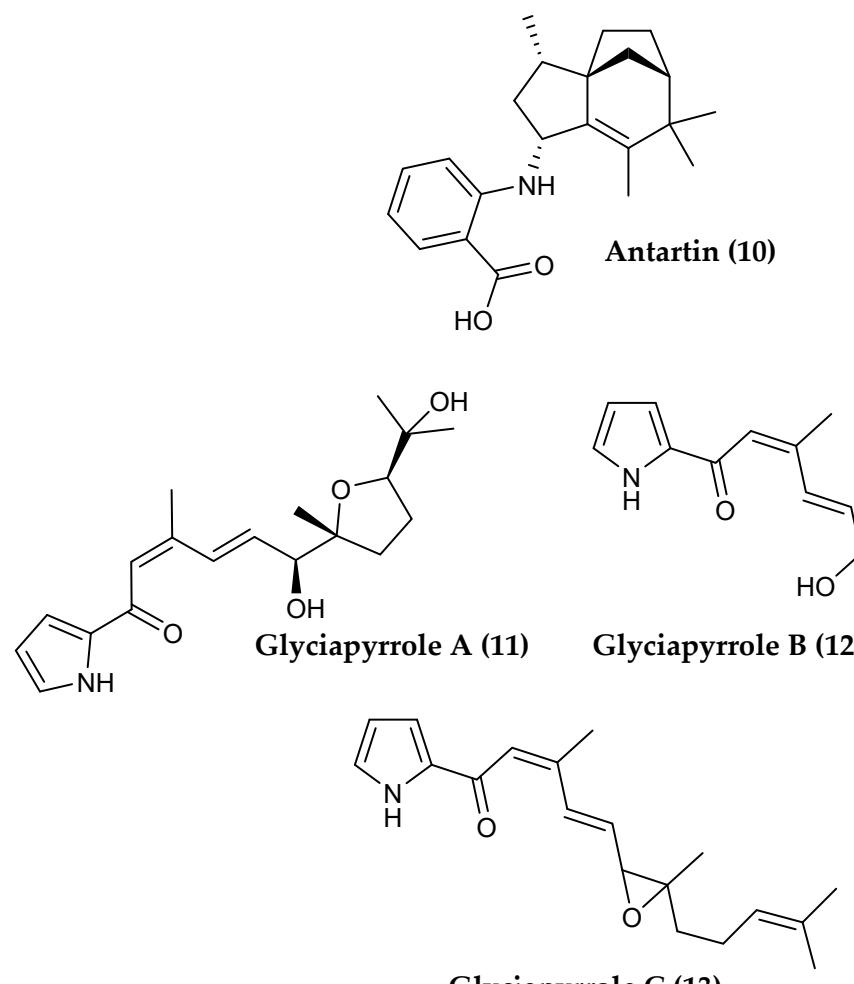

Glyciapyrrole C (13)

Figure 3. Structures of the sesquiterpenoid compounds (10) antartin A and (11-13) glyciapyrroles A-C from Streptomyces spp.

Penicillium sp. PR19N-1, a prolific producer of sesquiterpenes, is a fungus isolated from an Antarctic deep-sea sediment in Prydz Bay $(-1000 \mathrm{~m})$. It was found to contain four chlorinated eremophilane sesquiterpenes (14-17), along with a known sesquiterpenoid eremofortine $C$ (18) [90] and five eremophilane-type sesquiterpenes (19-23), a new rare lactam-type eremophilane (24), together with three previously reported compounds (25-27) (Figure 4) [91]. Compound 14 displayed moderate cytotoxic activity against HL-60 and A549 cancer cell lines [90], whereas compound 23 was the most active against the A-549 cells [91]. Eremophilane-type sesquiterpenes, a subclass of sesquiterpenoids, firstly identified in plants [185] and only decades later in fungi [186], are characterized by complex and unique structure and diverse biological properties, such as phytotoxic, antifungal, antibiotic and anticancer bioactivity [179]. They are composed of a terpene skeleton, where the isoprene units are connected head-to-head [187]. They have also been found from a deep marine-derived fungus, Aspergillus sp. SCSIOW2, grown after chemical epigenetic manipulation to be induced to produce these secondary metabolites [188] in marine-derived Xylariaceous fungus LL-07H239 [189] and in the mangrove endophytic fungus Xylaria sp. BL321 [190]. However, these chloro-eremophilane sesquiterpenes are the first examples found in microorganisms [90], and compound 23 represents a rare example of eremophilane-type lactam found in microorganisms [91]. To date, only four lactam-type compounds were reported [191-193].

Penicillium sp. S-1-18, a fungus isolated from Antarctic marine sediments, was reported to produce a new sesquiterpene guignarderemophilane $\mathrm{F}$, with no detectable activity, together with six known compounds, among them the sesquiterpenoid xylarenone A (28) (Figure 5) [93]. Compound 28, previously isolated from the endophytic fungal strain Xylaria sp. NCY2, exhibited moderate antitumor activities against HeLa and HepG2 (human liver carcinoma) cells and displayed growth-inhibitory effects against pathogenic microbes [94].

Illudalane sesquiterpenes are a group of potent bioactive products, with antimicrobial and cytotoxic properties, that are primarily found in terrestrial ferns (family Pteridaceae) (e.g., [194]) and fungi (phylum Basidiomycota) (e.g., [195]). In the marine realm, 15 illudalane sesquiterpenoids, 
alcyopterosins (indicated with letter from A to O) were isolated from the sub-Antarctic soft coral Alcyonium paessleri, which was collected at a depth of $200 \mathrm{~m}$ near the South Georgia Islands. Alcyopterosins A (29), C (30), E (31) and H (32) (Figure 6) demonstrated mild cytotoxicity toward the Hep-2 (human larynx carcinoma) cell line with an $\mathrm{IC}_{50}$ of $13.5 \mu \mathrm{M}$, while alcyopterosins $\mathbf{2 9}, \mathbf{3 0}$ and 32 displayed cytotoxicity toward HT-29 (human colon carcinoma) at an $\mathrm{IC}_{50}$ of $10 \mu \mathrm{g} \mathrm{mL}{ }^{-1}$ [104].<smiles>CC(=O)OC1C=C(Cl)C2=CC(=O)C(O)=CC2(C)C1C</smiles>

14<smiles>CC1C(O)C=C(Cl)C2=CC(=O)C3(CC21C)O[C@@]3(C)CO</smiles>

15<smiles>CC(C)=C1C[C@]2(C)C(=CC1=O)C(Cl)[C@H](O)C[C@H]2C</smiles>

16

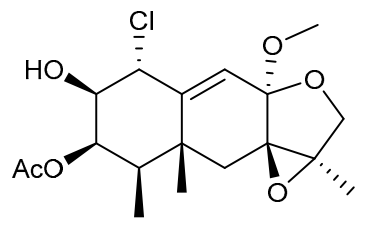

17

Chlorinated eremophilanes

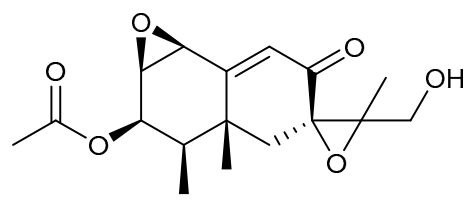

Eremofortine C (18)<smiles>C=C(C)[C@H]1C[C@]2(C)C(=CC(O)C[C@H]2C)C[C@H]1O</smiles>

19<smiles>CC1=C2CC3(C)C(=CC(=O)C(O)C3C)C=C2OC1=O</smiles>

22<smiles>[R]C1CC2(C)C(=CC=CC2O)C=C1C</smiles>

20

20<smiles>C=C(C)CCC</smiles>

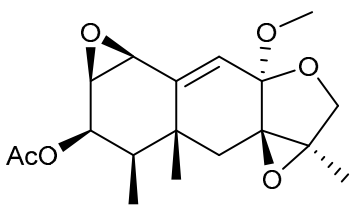

23<smiles>[R]C1C[C@@]2(C)C(=CC1=O)[C@@H](Br)CC[C@@H]2C</smiles>

21<smiles>C=C[Te]</smiles>

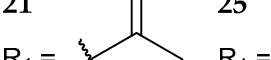
$R_{1}=$<smiles>CC1=CCCC1</smiles>

Eremophilanes<smiles>[R8]C1C=C2C=C3PC(=O)C(C)=C3CC2(C)C(C)C1OC(C)=O</smiles>

$24 \mathrm{R}_{1}=\mathrm{OCH}_{3} \mathrm{R}=\mathrm{NH}$

$27 \quad \mathrm{R}_{1}=\mathrm{OHR}=\mathrm{O}$

Figure 4. Structures of several sesquiterpenoid compounds from Penicillium sp. PR19N-1: (14-17) chlorinated eremophilane sesquiterpenes, (18) eremofortine $C$ and (19-27) several eremophilane-type sesquiterpenes.<smiles>C=C(CO)C12O[C@H]1[C@@]1(C)C(=CC2=O)C(O)CC[C@H]1C</smiles>

XylarenoneA (28)

Figure 5. Structure of the sesquiterpenoid compound (28) xylarenone A from Penicillium sp. S-1-18. 
<smiles>Cc1cc2c(c(C)c1CCCl)CC(C)(C)C2</smiles>

Alcyopterosin A (29)<smiles>Cc1cc2c(c3c1C(CO[N+](=O)[O-])OC3=O)CC(C)(C)C2</smiles>

Alcyopterosin C (30)<smiles>Cc1cc2c(c(C)c1CCO[N+](=O)[O-])CC(C)(C)C(=O)c1cc(C)c(CCO[N+](=O)[O-])c(C)c1C2</smiles>

Alcyopterosin E (31)

Figure 6. Structures of the sesquiterpenoid compounds (29-32) alcyopterosins A, C, E and H from Alcyonium paessleri.

Alcyonium paessleri from South Georgia Island further yielded two new sesquiterpenoids, paesslerins A and B (33 and 34) (Figure 7), with moderate cytotoxicity against human tumor cell lines [105]. The structures shown are revised based on the results of total synthesis of the originally proposed structures [196].<smiles>CC(=O)OC12CC[C@]1(C)[C@@H]1CC(C)(C)C[C@H]1C=C2C</smiles>

Paesslerin A (33)<smiles>C=C(C)[C@H]1[C@@H]2[C@@H](OC(C)=O)C[C@@H](C)[C@H]3[C@H](OC)C=C(C)[C@]213</smiles>

Shagene A (35)<smiles>CC(=O)O[C@H]1CC[C@]12CC(C)(C)C[C@H]2C=C(C)C</smiles>

Paesslerin B (34)<smiles>C=C(C)[C@H]1[C@@H](OC(C)=O)C[C@@H](C)[C@H]2C(=O)C=C(C)[C@]12C</smiles>

Shagene B (36)

Figure 7. Structures of the sesquiterpenoid compounds $(33,34)$ paesslerins A-B from Alcyonium paessleri and $(35,36)$ shagenes A-B from an undescribed soft coral.

Chemical examination of an undescribed soft coral collected from the Scotia Arc in the Southern Ocean resulted in the isolation and characterization of two new tricyclic sesquiterpenoids, shagenes A (35) and B (36) (Figure 7). Both compounds displayed significant inhibition against the visceral leishmaniasis, causing a parasite, Leishmania donovani, with no cytotoxicity against the mammalian host [113].

Octocorals or "horny corals" are conspicuous components on Antarctic sea bottoms, which extensively rely on natural products for protection. Eudesmane sesquiterpenes, ainigmaptilones A and B, seem to be taking part of the chemical arsenal of gorgonians Ainigmaptilon antarcticus from the Weddell Sea. Ainigmaptilone A was found to display ecologically relevant activities, in repelling putative sea star predators, and block fouling or microbial infections caused by sympatric bacteria strains and diatoms [197]. Antifouling properties have also been reported in azulenoid sesquiterpenes (i.e., linderazulene, ketolactone 2, and a new brominated C-16 linderazulene derivative) isolated from another Antarctic gorgonian, Acanthogorgia laxa [198]. The nudibranch gastropod, Bathydoris hodgsoni, 
from the Weddell Sea revealed high concentrations of a new drimane sesquiterpene, hodgsonal, exclusively allocated in the mantle. Hodgsonal has been hypothesized to be de novo synthesized and to play a defensive role, by analogy with drimane sesquiterpenes in other dorid nudibranchs $[199,200]$.

\subsubsection{Diterpenes and Diterpenoids}

Diterpenes are composed of "two monoterpene units," or four isoprene subunits [171]. They are pharmacologically interesting compounds for possessing antimicrobial, antiviral, antiparasite, anticancer and anti-inflammatory properties [201].

A rare spirocyclic diterpene, named spirograterpene A (37), was isolated from the deep-sea fungus Penicillium granulatum MCCC 3A00475 [92] from Prydz Bay, Antarctica, together with two known biosynthetically-related cyclopianes, conidiogenone I (38) [202] and conidiogenone C (39) (Figure 8) [203]. Spirograterpene A displays an anti-allergic effect on immunoglobulin E (IgE)-mediated rat mast RBL-2H3 cells, displaying 18\% inhibition compared with the positive control, loratadine, with $35 \%$ inhibition at the same concentration of $20 \mu \mathrm{g} / \mathrm{mL}$ [92]. Cyclopianes, belonging to a rarely reported diterpenoid family, are tetracyclic diterpenes characterized by a highly fused and rigid ring system of 6/5/5/5 skeleton. They were first identified in the fungus Penicillium cyclopium in 2002 [204], followed by related compounds, all of which have been obtained only in the Penicillium species [202-205]. Spirograterpene A (37) is the second example of a diterpene spiro-tetracyclic skeleton with a 5/5/5/5 ring system [92], demonstrating that marine fungi represent a unique source of structurally novel compounds.

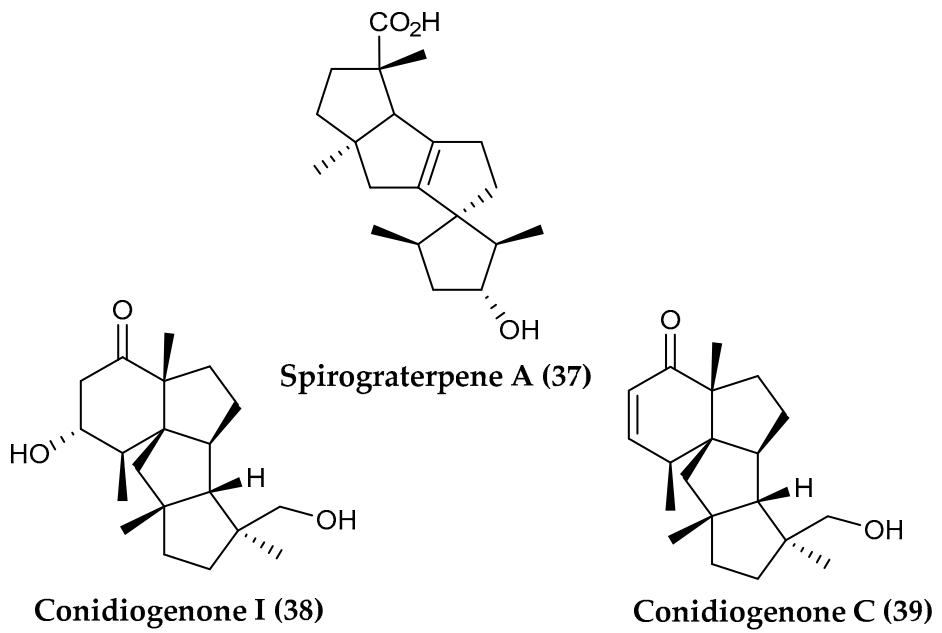

Figure 8. Structures of the diterpenoid compounds (37) spirograterpene A and $(38,39)$ conidiogenone I and $\mathrm{C}$ from Penicillium granulatum.

Among marine invertebrates, cnidarians, and in particular corals, have been found to possess a wide variety of diterpene and diterpenoid products, likely mediating allelochemical interactions [206]. Cold water polar ecosystems are devoid of scleractinian coral reef formations, such as those in the tropics, but instead harbor rich communities of soft-bodied octocorals that are well-known for their chemical diversity $[16,207,208]$. The Arctic soft coral Gersemia fruticosa, collected in the Bering sea, revealed the presence of three diterpenes named gersemiols $\mathrm{A}-\mathrm{C}$ and another eunicellane diterpene, eunicellol A, which were purified together with the known sesquiterpene (+)- $\alpha$-muurolene. Eunicellol A (40) (Figure 9) was found to exhibit moderate and selective antibacterial activity against methicillin-resistant Staphylococcus aureus (MRSA) [111].

Five new furanocembranoid diterpenes, keikipukalides A-E (41-45), the known diterpene pukalide aldehyde (46) and the known norditerpenoid ineleganolide (47) (Figure 10) were isolated from the octocoral Plumarella delicatissima collected between 800 and $950 \mathrm{~m}$ depth, and demonstrated inhibitory activity against $L$. donovani [112]. 


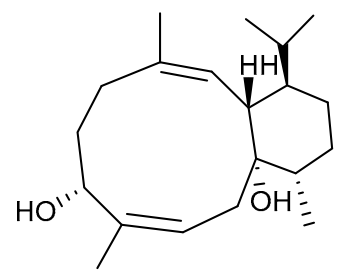

\section{Eunicellol A (40)}

Figure 9. Structure of the sesquiterpene compound (40) eunicellol A from Gersemia fruticosa.

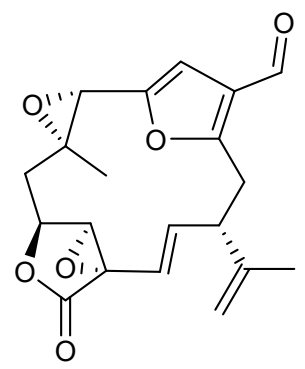

Keikipukalide A (41)<smiles>C=C(C)[C@H]1Cc2oc(cc2C=O)[C@@H](O)C[C@@H]1OC(C)=O</smiles>

Keikipukalide B (42)

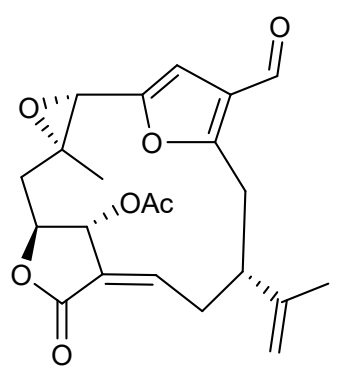

Keikipukalide C (43)<smiles>C=C(C)[C@H](/C=C/C1=C[C@@H](C[C@@](C)(O)[C@H](OC(C)=O)c2cc(C=O)c(C[C@@H]3C=C(C=O)OC3=O)o2)O1)C(C)=O</smiles>

Keikipukalide D (44)<smiles>C=C(C)[C@@H]1CCC(Cc2oc([C@@H]3O[C@H]3C[C@H]3C=C(C=O)OC3=O)cc2C=O)=C[C@@H]1C</smiles>

Pukalide aldehyde (46)

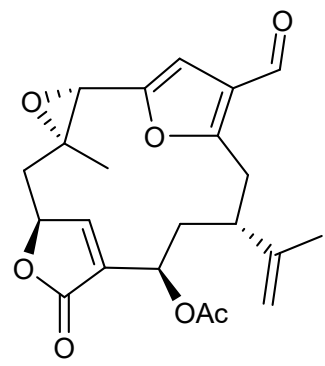

Keikipukalide E (45)

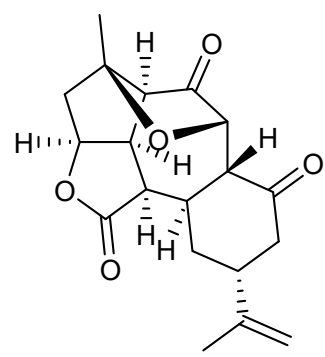

Ineleganolide (47)

Figure 10. Structures of the diterpenoid compounds (41-45) keikipukalides A-E, (46) pukalide aldehyde and (47) ineleganolide from Plumarella delicatissima.

The feather boa sea pen, Anthoptilum grandiflorum, is a cosmopolitan pennatulacean octocoral. Specimens collected at 662 and $944 \mathrm{~m}$ depth north of Burdwood Bank (Scotia Arc) yielded three new briarane diterpenes, bathyptilone A (48) (Figure 11), B and C together with a trinorditerpene, enbepeanone A. Nanomolar cytotoxicity against the neurogenic mammalian cell line Ntera-2 was detected only for bathyptilone A [107]. 


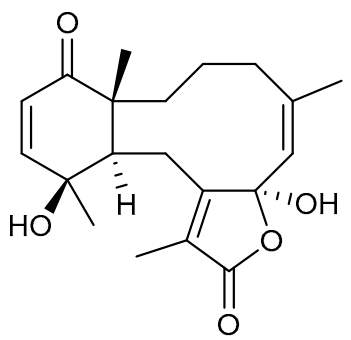

Bathyptilone A (48)

Figure 11. Structure of the diterpene compound (48) bathyptilone A from Anthoptilum grandiflorum.

The gastropod Austrodoris kerguelenensis is considered the most common and conspicuous Antarctic nudibranch, and among the most studied polar species for chemical ecology $[13,14,209]$. Detailed investigation of specimens from the vicinities of Palmer Station (Western Antarctic Peninsula), McMurdo Sound and the Weddell Sea has resulted in the isolation of a suite of tricyclic diterpenoid 2'-monoglyceryl esters (i.e., austrodorin A-B) [210] and diterpenoic acid glycerides [i.e 2'-acetoxyglyceryl (5R,10R,13R)-labda-8-en-15-oate, $3^{\prime}$-acetoxyglyceryl (5R,10R,13R)-labda8-en-15-oate] [211], which were hypothesized to be produced by the nudibranch cells as opposed to being accumulated from its sponge diet [200]. Out of the variety of diterpene and diterpenoid products known from this mollusk, palmadorins A (49), B (50), D (51), M (52), N (53) and O (54) (Figure 12) proved to inhibit human erythroleukemia (HEL) cells and palmadorin M blocks Jak2, STAT5 and Erk1/2 activation in HEL cells, in addition to causing apoptosis [116].<smiles>C=C1CCC[C@H]2[C@@H](C)[C@H](C)CC[C@]1(C)[C@@H]2C/C(C)=C/C(=O)OC(CO)CO</smiles>

Palmadorin A (49)<smiles>C=C1CCC[C@H]2[C@@H](C)CC[C@H](C)[C@]12CC/C(C)=C/C(=O)OC[C@H](O)CO</smiles>

Palmadorin D (51)<smiles>C=C(/C=C(\C)CC[C@@H]1C(=C)CC[C@H]2C(C)(C)CCC[C@@]21C)COC[C@H](O)CO</smiles>

Palmadorin N (53)<smiles>C=C1CCC[C@H]2[C@@H](C)[C@](C)(CC/C(C)=C/C(=O)OC(CO)COC(C)=O)[C@H](C)CC[C@]12C</smiles>

Palmadorin B (50)<smiles>C=C(/C=C(\C)CC[C@H]1C(=C)CC[C@H]2C(C)(C)CCC[C@]12C)OC(CO)CO</smiles>

Palmadorin M (52)<smiles>C=C(/C=C(\C)CC[C@H]1C(=C)CC[C@H]2C(C)(C)CCC[C@]12C)O[C@H](CO)COC(C)=O</smiles>

Palmadorin O (54)

Figure 12. Structure of the diterpenoid compounds (49-54) palmadorins A, B, D, M, N and O from Austrodoris kerguelenensis.

Sponges are known to be a particularly rich source of defensive diterpenoids, and among polar species, Antarctic Dendrilla sponges, typically reported as D. membranosa (recently revised to D. antarctica), stand out as the most prolific producers of bioactive diterpenes. While the chemical 
ecology of this sponge has been well-studied, investigations into the bioactive potential of Antarctic Dendrilla sponges was not carried out until 2004, with aplysulphurin (55) isolated from methanolic extracts along with three methyl acetals $(56,58,60)$ (Figure 13), which displayed moderate antifungal activity against Candida albicans, and antibiotic activity against S. aureus and Escherichia coli [123]. Termed "membranolides B-D" at the time of original publication, more recent investigations have shown these acetals to be artifacts from the methanolysis of aplysulphurin and have yielded several additional semisynthetic methyl acetal variations of the scaffold, now known collectively as membranoids A-H (56-62) (Figure 13). As a whole, the membranoids show potent bioactivity against the leishmaniasis causing parasite $L$. donovani, with membranoids B (57), D (59) and G (61) most notably displaying $\mathrm{IC}_{50}$ values of $0.8 \mu \mathrm{M}, 1.4 \mu \mathrm{M}$ and $1.9 \mu \mathrm{M}$, respectively, against L. donovani infected J774A.1 macrophages, with no discernable cytotoxicity observed towards the healthy variant of human cells [124].<smiles>CC(=O)OC1Cc2ccc([C@]3(C)CCCC(C)(C)C3)c3c2[C@@H](C)C(=O)O[C@H]3O1</smiles>

Aplysulphurin (55)<smiles>CO[C@H]1OC(=O)[C@H](C)c2c([C@@]3(C)CCCC(C)(C)C3)ccc(C=O)c21</smiles>

Membranoid A (56)<smiles>CO[C@H]1O[C@H](OC)c2c1ccc([C@H](C)C(=O)O)c2[C@]1(C)CCCC(C)(C)C1</smiles>

Membranoid B (57)<smiles>CO[C@H]1O[C@H](OC)c2c1ccc([C@]1(C)CCCC(C)(C)C1)c2[C@H](C)C(=O)O</smiles>

Membranoid C (58)<smiles>CO[C@H]1O[C@H](OC)c2c1ccc([C@]1(C)CCCC(C)(C)C1)c2[C@H](C)C(=O)O</smiles>

Membranoid D (59)<smiles>CO[C@H]1O[C@H](OC)c2c1ccc([C@]1(C)CCCC(C)(C)C1)c2[C@H](C)C(=O)O</smiles>

Membranoid E (60)<smiles>C[C@H]1C(=O)O[C@H](O)c2c(C=O)ccc([C@@]3(C)CCCC(C)(C)C3)c21</smiles>

Membranoid G (61)<smiles>CO[C@H]1O[C@H](OC(C)=O)c2c1ccc([C@]1(C)CCCC(C)(C)C1)c2[C@@H](C)C(=O)O</smiles>

Membranoid H (62)

Figure 13. Structures of the diterpenoid compounds (55) aplysulphurin and (56-62) membranolids A, B, C, D, E, G and H from Dendrilla membranosa.

Dendrilla sponges from around Anvers Island, Antarctica, have yielded several further diterpenoid natural products, including darwinolide (63), which was tested against MRSA and was found to be four times more potent against the biofilm $(33.2 \mu \mathrm{M})$ than the planktonic form of MRSA $(132.9 \mu \mathrm{M})$. This type of selective toxicity towards biofilms is rare and a promising lead in the search for antibiofilm-specific antibiotics [125]. A recent continuation of that study revealed a library of diterpenoids containing both known (64-70) (Figure 14) and new (71-73) natural products along with several additional semisynthetic derivatives (74-76) (Figure 15). This small but diverse collection of diterpenoids showed remarkable antibiotic properties against a range of infectious disease models. The most prominent bioactivity including membranolide (66) showed $>90 \%$ eradication of MRSA biofilm at or below concentrations of $25 \mu \mathrm{g} / \mathrm{mL}$, dendrillin B (71), active against L. donovani infected J774A.1 at macrophages at an $\mathrm{IC}_{50}$ of $3.5 \mu \mathrm{M}$, and 76 with $100 \%$ inhibition of $P$. falciparum at $5 \mu \mathrm{g} / \mathrm{mL}$ [126]. 9,11-dihydrogracilin A (64) isolated from Dendrilla sponges collected around the same area, has also recently been shown to display immuno-modulatory and anti-inflammatory properties in human cell lines [127].

\subsubsection{Sesterterpenes and Sesterterpenoids}

Sesterterpenes are composed of "two and a half monoterpene units" and are typically $\mathrm{C}_{25}$, resulting from an initial condensation between DMAPP and isopentenyl IPP pyrophosphate followed by three additional and consecutive condensations of IPP to add to the growing chain. Sesterterpenes are the longest of the terpenes to be formed in this fashion, as subsequently longer terpenes with 30+ carbons are formed by additional condensation of two preformed phosphorylated isoprene precursors [212]. 
Sesterterpenoids are not as commonly found in the marine polar environment compared to diterpenes or triterpenes, however, sponges of the Suberites genus collected at several spots around Antarctica including King George Island and McMurdo Sound have yielded the polycyclic suberitenones A and B $(77,78)$ (Figure 16), the latter of which has been shown to inhibit the cholesteryl ester transfer protein (CETP). This CETP protein mediates the transfer of cholesterol ester and triglyceride between high-density lipoproteins (HDL) low-density lipoproteins (LDL) and is a major target for the development of atherosclerotic disease treatments [142].

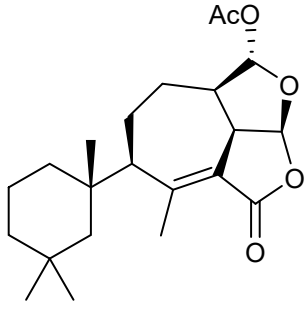

Darwinolide (63)<smiles>C/C=C1\C(C2(C)CCCC(C)(C)C2)CC[C@@H]2[C@@H]1[C@H](OC(C)=O)O[C@@H]2OC(C)=O</smiles>

9,11-dihydrogracilin A (64)<smiles>CC(=O)O[C@H]1O[C@@H]2OC(=O)[C@H](C)C3=C([C@]4(C)CCCC(C)(C)C4)CC[C@@H]1[C@@H]32</smiles><smiles>COC(=O)[C@H](C)c1c([C@@]2(C)CCCC(C)(C)C2)ccc2c1C(=O)OC2</smiles><smiles>CC(=C1CCCC1(C)C)C1CCC2C(=O)OCC2C1(C)C</smiles>

Glaciolide (67)<smiles>CC(=O)O[C@@H]1O[C@H](OC(C)=O)[C@H]2CCC(/C(C)=C3/CCCC3(C)C)C(C)(C)[C@@H]12</smiles>

68<smiles>C[C@H]1C(=O)OC2OCC3CCC([C@]4(C)CCCC(C)(C)C4)=C1C32</smiles>

Cadlinolide C (69)

\section{Membranolide (66)}

Figure 14. Structures of further diterpenoid compounds from Dendrilla membranosa: (63) darwinolide, (64) 9,11-dihydrogracilin A, (65) tetrahydroaplysulphurin-1, (66) membranolide, (67) glaciolide, (68), (69) cadlinolide $\mathrm{C}$ and (70) dendrillin A.<smiles>COC(=O)[C@H](C)c1c(C(C)(C)C)ccc2c1C(O)OC2=O</smiles>

Dendrillin B (71)<smiles>CCC1=C(C=O)C(C(=O)OC)CC[C@H]1C1(C)CCCC(C)(C)C1</smiles>

Dendrillin C (72)<smiles>CC(=O)OC[C@H]1CC[C@H]([C@]2(C)CCCC(C)(C)C2)C2=C1C(=O)O[C@H]2C</smiles>

Dendrillin D (73)<smiles>CO[C@H]1O[C@H](OC(C)=O)[C@H]2C(=O)[C@H](C3(C)CCCC(C)(C)C3)CC[C@H]12</smiles>

74<smiles>CC(=O)OC1OC2OC(=O)[C@H](C)[C@]3(OO[C@]4(C)CCCC(C)(C)C4)CC[C@]12OO3</smiles>

75<smiles>C[C@H](CO)c1c(CO)ccc(CO)c1[C@]1(C)CCCC(C)(C)C1</smiles>

76

Figure 15. Structures of diterpenoid compounds from Dendrilla membranosa, (71-73) dendrillins B, C and $\mathrm{D}$ and semisynthetic derivatives (74-76). 


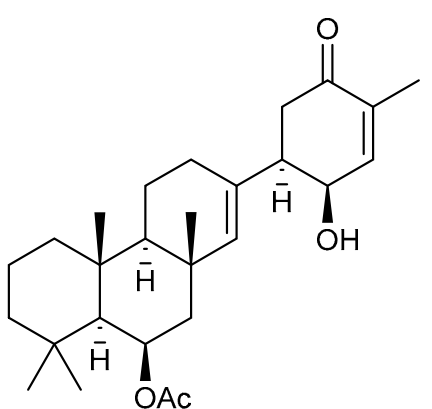

Suberitenone A (77)

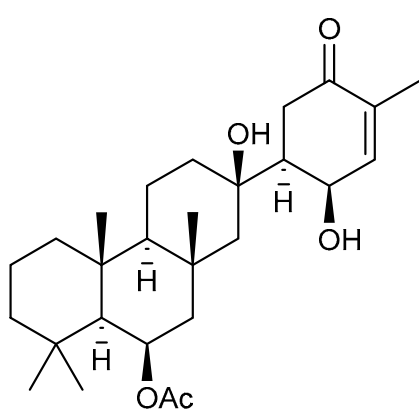

Suberitenone B (78)

Figure 16. Structures of the sesterterpenoid compounds $(\mathbf{7 7}, \mathbf{7 8})$ suberitenones A-B from Suberites spp.

\subsubsection{Triterpenes and Triterpenoids}

Triterpenes are formed by six isoprene units, conceptualized as three monoterpene units. Functionalized triterpenes (containing heteroatoms substitutions) should instead be referred to as triterpenoids. Animals, plants and fungi all produce triterpenes and triterpenoids, which exist in $\sim 200$ different skeletons and a great variety of structures (e.g., cholesterol) [213].

\section{Steroids}

Animals, plants and fungi all produce triterpenes, among which is squalene, the precursor to all steroids. These contain a core moiety of the triterpene cucurbitane, and in practice are biosynthesized from either lanosterol (animals and fungi) or cycloartenol (plants) via the cyclization of squalene. Steroids are further metabolized from squalene via subsequent demethylation to a tri-nor $\mathrm{C}_{27}$ skeleton, or further still to even smaller steroids. Steroids have two principal biological functions, being either key components of cell membranes or signaling molecules. Some examples of steroids are vitamin D3, the lipid cholesterol, the sex hormones estradiol and testosterone and the anti-inflammatory drug dexamethasone [214].

The Alcyonacean octocoral Anthomastus bathyproctus Bayer 1993 collected in the South Shetland Islands (Antarctica) afforded seven steroids, all of them displaying a cross-conjugated ketone system in the A ring of the tetracarbocyclic nucleus, while their side chains belong to the cholestane, ergostane and 24-norcholestane types. Compounds $\mathbf{7 9}$ to 82 (Figure 17) showed diverse in vitro cytotoxicity against the human tumor cell lines MDA-MB-231 (breast adenocarcinoma), A-549 (lung carcinoma) and HT-29 (colon adenocarcinoma) [106].

Dasystenella acanthina collected from Kapp Norvegia (Eastern Weddell Sea, Antarctica) was found to possess seven polyoxygenated steroids (83-89) (Figure 18). All compounds displayed some sort of growth inhibitory activity on tumor cell lines, including DU-145 (prostate carcinoma), LN-caP (prostate carcinoma), IGROV (ovarian adenocarcinoma), SK-BR3 (breast adenocarcinoma), SK-MEL-28 (melanoma), A549 (lung adenocarcinoma), K-562 (chronic myelogenous leukemia), PANC1 (pancreas carcinoma), HT29 (colon adenocarcinoma), LOVO (colon adenocarcinoma), LOVO-DOX (colon adenocarcinoma resistant to doxorubicin) and HeLa (cervix epithelial adenocarcinoma). The most affected cell lines were LN-caP and K-562. Compounds $\mathbf{8 8}$ and $\mathbf{8 9}$ presented broader cytostatic effects, and compound 89 was active against all tested cell lines [108].

Six polyoxygenated sterols (90-95) (Figure 19) were isolated from the soft coral Gersemia fruticosa, exhibiting a moderate cytotoxic activity against human erythroleukemia K-562 cells and other leukemia cell lines [109].

Gersemia fruticosa was also found to contain further a bioactive 9,11-secosterol steroid, named 24-nor-9,11-seco-11-acetoxy-3,6-dihydroxycholest-7,22(E)-dien-9-one (96) (Figure 20). This compound was shown to yield growth inhibition ( $\mathrm{IC}_{50}$ below $\left.10 \mu \mathrm{M}\right)$ and cytotoxicity against human leukemia K562, human cervical cancer HeLa and Ehrlich ascites tumor cells in vitro [110]. 


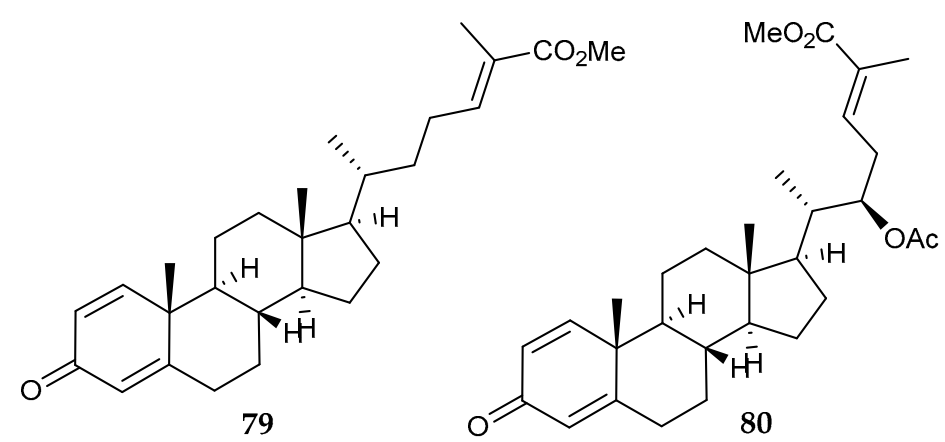

Conjugated cholestane, ergostane and 24-norcholestane steroids

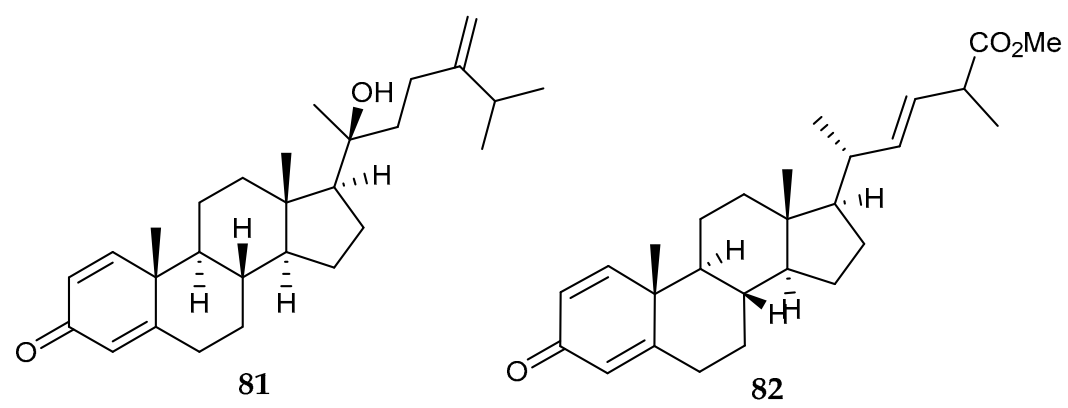

Figure 17. Structures of several steroid compounds (79-82) from Anthomastus bathyproctus.

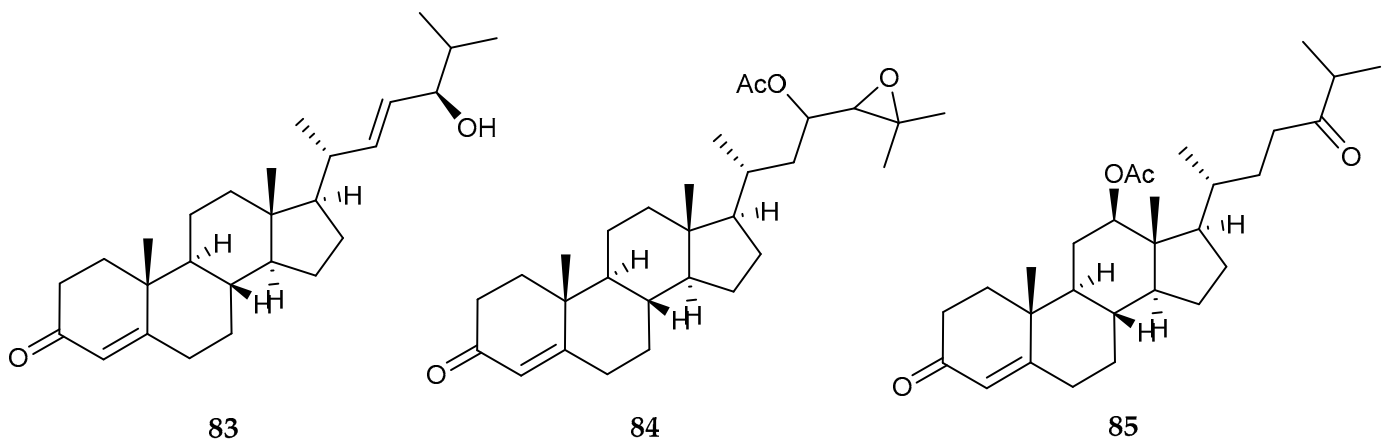

Polyoxygenated steroids from D. acanthina

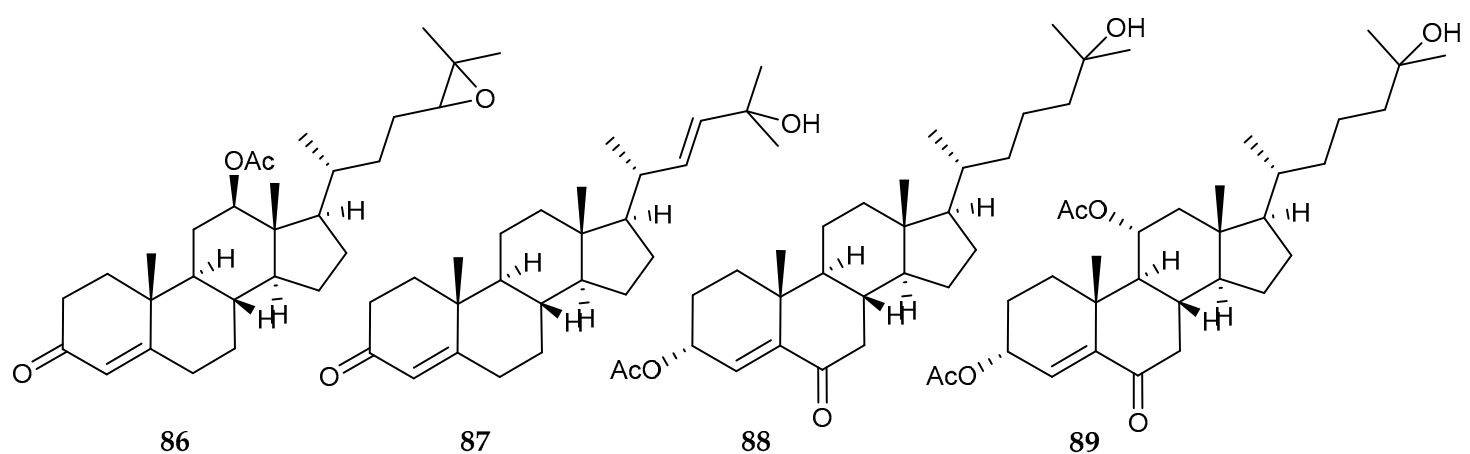

Figure 18. Structures of polyoxygenated steroid compounds (83-89) from Dasystenella acanthina.

Sponges are known to produce a wide variety of bioactive steroids and steroid derivatives, and the species found in polar waters are no exception. A red encrusting sponge within the genus Crella is commonly found on the sheer walls in the shallow waters along the Western Antarctic Peninsula, and a group of specimens collected around Norsel Point near Anvers Island yielded norselic acids A-E (97-101) (Figure 21). Among these oxidized steroids, the most abundant, norselic acid A, 
showed inhibitory activity against MRSA and vancomycin-resistant Enterococci faecium (VREF) in addition to antifungal activity against $C$. albicans. All of the norselic acids showed low micromolar activity against the leishmaniasis causing protozoan parasite $L$. donovani with potencies ranging from 2.0-3.6 $\mu \mathrm{M}$ [122].<smiles>CC(C)=CCC[C@H](C)[C@H]1CCC2C3C(O)[C@H](O)C4C[C@@H](O)CC[C@]4(C)C3CC[C@]21C</smiles>

Polyoxygenated steroids from $G$. fruticosa

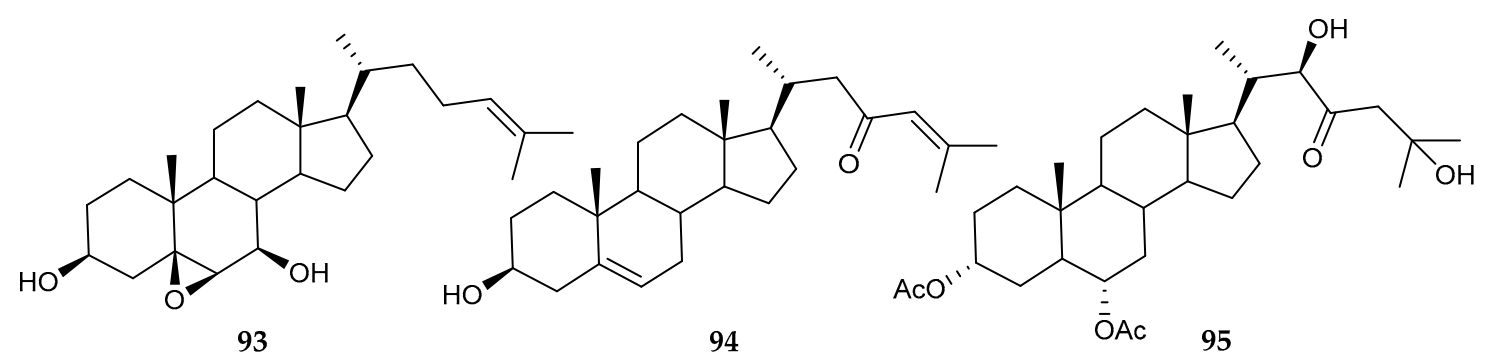

Figure 19. Structures of polyoxygenated steroid compounds (90-95) from Gersemia fruticosa.

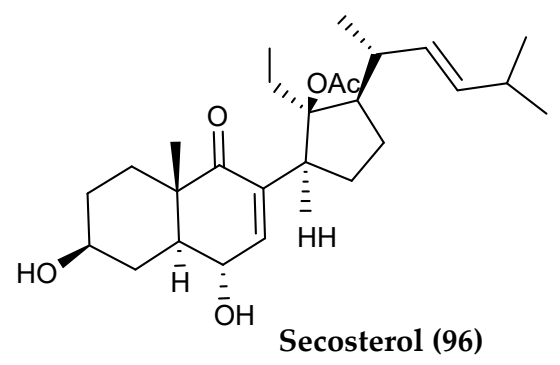

Figure 20. Structure of a further steroid compound (96) from Gersemia fruticosa.<smiles>C=C(C)[C@](O)(CC)CC[C@H](C)C1CCC2C3C=CC4=CC(=O)C=C[C@]4(C)C3CC[C@@]21C</smiles>

Norselic acid A (97)<smiles>C=C(C)[C@](O)(CC)CC[C@H](C)C1CCC2C3CCC4CC(=O)C=C[C@]4(C)C3CC[C@@]21C</smiles>

Norselic acid B (98)

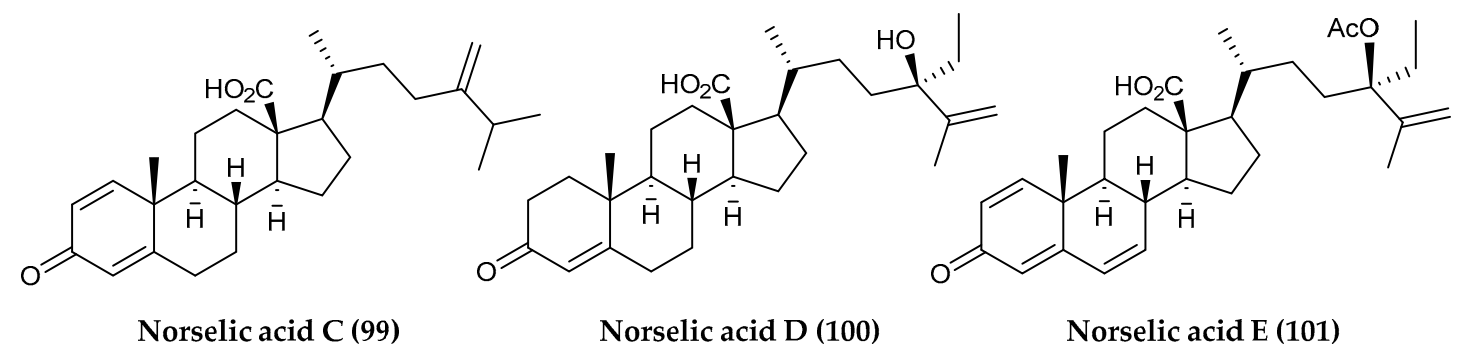

Figure 21. Structures of steroid compounds (97-101) from Crella sp. 
Sulphated polyhydroxysteroids, obtained from Antarctic brittle star species, have been providing promising antiviral properties. Ophiuroid Ophiosparte gigas, coming from $70 \mathrm{~m}$ depth in the Ross Sea area revealed the presence of cholest-5-ene-2 $\alpha, 3 \alpha, 4 \beta, 21$-tetrao1-3,21-disulphate (102), which was remarkably cytotoxic, along with cholest-5-ene-2 $\beta, 3 \alpha, 21$-triol-2,21-disulphate (103) with cytoprotective activity against HIV-1 (Figure 22) [120]. Further disulfated polyhydroxysteroids (104-106) from another Antarctic ophiuroid, Astrotoma agassizii (Figure 22), as well as their synthetic derivatives displayed antiviral activities against one DNA (HSV-2) and two RNA (PV-3, JV) viruses [121].

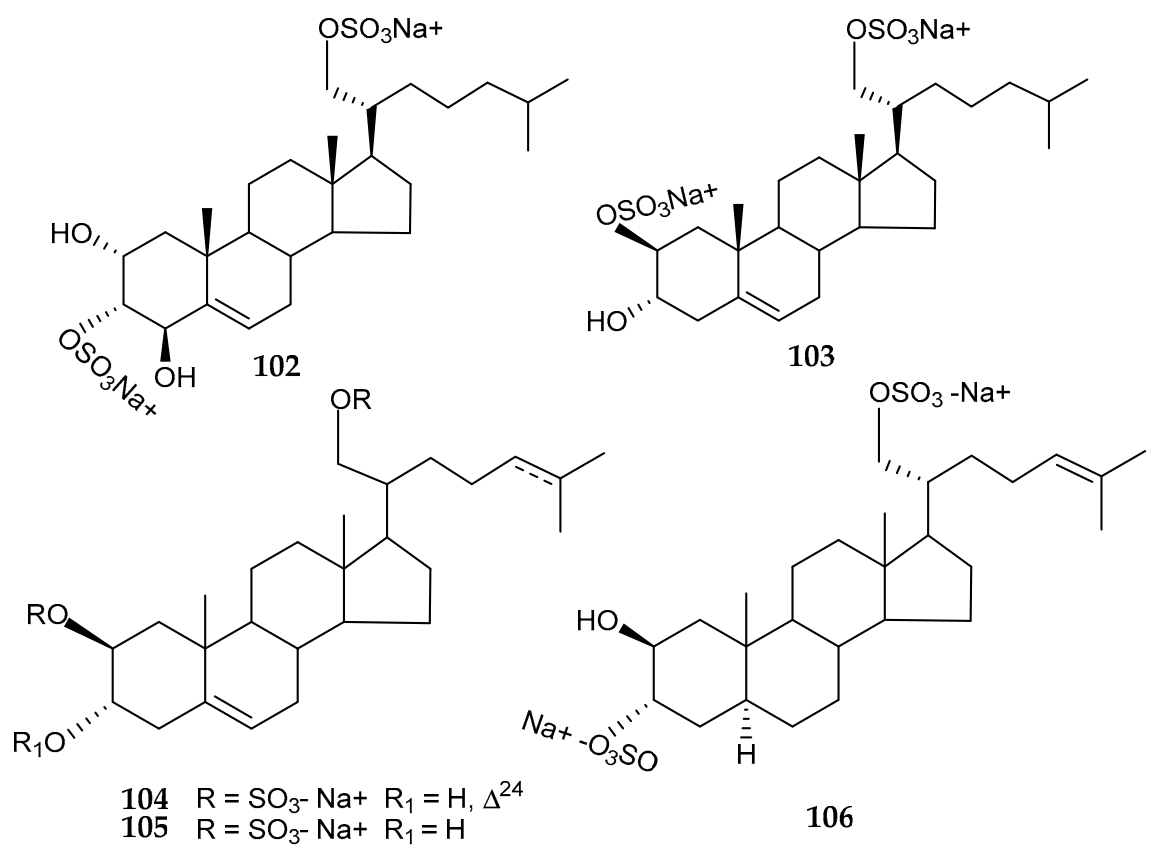

Figure 22. Structures of sulphated polyhydroxysteroids compounds $(\mathbf{1 0 2}, \mathbf{1 0 3})$ from Ophiosparte gigas and (104-106) from Astrotoma agassizii.

Despite being most well-known for their role as hormones regulating molting in arthropods, a surprising array of unique ecdysteroids have been found in the Antarctic ascidian Synoicum adareanum, some of which display promising therapeutic activities. Among these are hyousterones $\mathrm{A}$ and $\mathrm{C}$ $(107,108)$ (Figure 23) which displayed $\mathrm{IC}_{50}$ values of $10.7 \mu \mathrm{M}$ and $3.7 \mu \mathrm{M}$, respectively, against the HCT-116 colon cancer cell line, while abeohyousterone (109) (Figure 23) was active at 3.0 $\mu \mathrm{M}$ in the same biological assay, all of which were isolated from tunicates around Anvers Island [149].

\subsubsection{Tetraterpenes and Tetraterpenoids}

\section{Carotenoids}

Tetraterpenes are terpenes built from eight isoprene units (four monoterpene units). Carotenoids belong to the category of tetraterpenoids. They are natural isoprenoid pigments derived from head-to-tail condensation of two $C_{15}$ or $C_{20}$ isoprenoid precursors to form a $C_{30}$ or $C_{40}$ backbone, respectively, which are then modified to obtain different carotenoid structures [215]. They are divided into two main classes: carotenes, which are hydrocarbons, and xanthophylls, oxygenated derivatives of carotenes. Due to the long system of conjugated double bonds, they are able to capture and absorb light in the $400-500 \mathrm{~nm}$ range, displaying a peculiar strong coloration [216]. For this feature, carotenoids play a critical role in the photosynthesis process and provide photo-oxidative protection to the cells acting as strong antioxidant compounds. Being chemical quenchers of singlet oxygen, they function as potent scavengers of reactive oxygen species (ROS) [216]. They are essential constituents of photosynthetic organisms (e.g., plants, algae and cyanobacteria), but have been found also in fungi and bacteria [217]. Not synthesized by humans or animals, they are present in their blood and tissues, deriving from 
dietary sources. Being precursors of retinol (vitamin A), they perform a role of particular significance to human health [216].<smiles>C[C@H](CCCC(C)(C)O)[C@H]1CC[C@]2(O)C3=CC(=O)C4=C[C@H](O)[C@@H](O)C[C@]4(C)[C@H]3CC[C@]12C</smiles><smiles>C[C@H](CCCC(C)(C)O)[C@H]1CCC2(O)C3=CC(=O)C4=C[C@H](O)[C@@H](O)C[C@]4(C)C3CC[C@@]12C</smiles><smiles>C[C@H](CCCC(C)(C)O)[C@H]1CCC(=O)[C@@]23CC(=O)C4=C[C@@H](O)[C@@H](O)C[C@]4(C)[C@H]2CC[C@]13C</smiles>

Abeohyousterone (109)

Figure 23. Structures of ecdysteroid compounds $(\mathbf{1 0 7}, \mathbf{1 0 8})$ hyousterones A-B and $(\mathbf{1 0 9})$ abeohyousterone from Synoicum adareanum.

In fact, carotenoids from marine environments are strong antioxidants used as nutraceutical ingredients in the food industry and cosmeceutical molecules for the photoprotection against UV radiation [218,219].

Although marine animals do not synthesize carotenoids de novo, they contain significant amounts of carotenoids derived from dietary sources. More than 100 carotenoids have been isolated from sponges, cnidarians, mollusks, crustaceans, echinoderms, tunicates and fishes [220].

Marine organisms inhabiting polar environments have developed a variety of adaptive strategies to cope with UV radiation, including light avoidance mechanisms, synthesis of UV-sunscreens, enzymatic and non-enzymatic quenching of ROS and DNA repair mechanisms [2]. The synthesis of carotenoid pigments in the Antarctic marine organisms belongs to the antioxidant defense mechanisms able to counteract ROS damage [2].

Indeed, some pigmented bacteria owe their colors to the presence of carotenoids. The genome mining of Marisediminicola antarctica ZS314T, isolated from intertidal sediments of the cost near the Chinese Antarctic Zhongshan Station in East Antarctica, demonstrated the biosynthetic potential of this orange Actinobacterium in producing carotenoids and their derivatives [221]. Cellulophaga fucicola strain 416 and Zobellia laminarie 465, yellow and orange pigmented bacteria, respectively [98,99], isolated from Antarctic sea sponges, were found to be resistant to UV-B and UV-C radiation, thanks to the expression of carotenoids isolated and chemically identified by ultra-high-performance liquid chromatography with photodiode array and mass spectrometry detectors. Zeaxanthin (110), $\beta$-cryptoxanthin (111) and $\beta$-carotene (112) were identified in both strains, whereas two isomers of zeaxanthin was identified only in C. fucicola [98] and phytoene (113) only in Z. laminarie (Figure 24) [99]. These pigments displayed a very high antioxidant activity, although they were shown to be phototoxic in murine fibroblast lines [98,99].

The red-orange strain Rhodococcus sp. B7740, isolated from $25 \mathrm{~m}$ deep-sea water in the Arctic Ocean, is a promising source of natural carotenoids and isoprenoid quinones, interesting both in amounts and varieties for the application in the food industry [74]. Among them, synechoxanthin ( $x, x$-caroten-18,18' -dioic acid) (114), a unique aromatic dicarboxylate carotenoid, recently discovered only in some cyanobacteria [222,223], dehydrogenated menaquinones with eight isoprene units [MK-8 $\left.\left(\mathrm{H}_{2}\right)\right]$ (115), produced in higher concentration than that reported in other bacteria [224], and isorenieratene (116), an aromatic carotenoid used in smear cheese industry [225], have been 
identified (Figure 25). The latter is a promising metabolite in future food and medicine applications for its higher stability than $\beta$-carotene and lutein in model gastric conditions and for its high retention rate in the gastrointestinal tract after ingestion [74]. Moreover, it has been demonstrated that isorenieratene, able to prevent UV-induced DNA damage in human skin fibroblasts [226], displays a photoprotective effect against UV-B radiation compared with two macular xanthophylls, lutein and zeaxanthin, in the multilamellar vesicles model and human retina cell model [75]. Additionally, $\mathrm{MK}-8\left(\mathrm{H}_{2}\right)$, the main menaquinone from Rhodococcus sp. B7740, has a potential application in the field of medicine for its higher antioxidant effect and antiglycation capacity compared with ubiquinone $\mathrm{Q} 10$ and $\mathrm{MK}_{4}$ [76].<smiles>CC1=C(/C=C/C(C)=C/C=C/C(C)=C/C=C/C=C(C)/C=C/C=C(C)/C=C/C2=C(C)C[C@@H](O)CC2(C)C)C(C)(C)C[C@H](O)C1</smiles><smiles>CC1=CCCC(C)(C)[C@H]1/C=C/C(C)=C/C=C/C(C)=C/C=C/C=C(C)/C=C/C=C(C)/C=C/C1=C(C)C[C@@H](O)CC1(C)C</smiles>

$\beta$-cryptoxanthin (111)<smiles>CC1=C(/C=C/C(C)=C/C=C/C(C)=C/C=C/C=C(C)/C=C/C=C(C)/C=C/C2=C(C)CCCC2(C)C)C(C)(C)CCC1</smiles><smiles>CC(C)=CCC/C(C)=C/CC/C(C)=C/C=C/C=C(\C)CC/C=C(\C)CC/C=C(\C)CC/C=C(\C)CCC=C(C)C</smiles>

Figure 24. Structures of carotenoids found in bacteria Cellulophaga fucicola 416 and Zobellia laminarie 465: (110) zeaxanthin, (111) $\beta$-cryptoxanthin, (112) $\beta$-carotene and (113) phytoene.

\subsubsection{Triterpene and Triterpenoid Derivatives}

Triterpenoid Conjugates

While steroids come in a variety of forms, they can also be found conjugated to other functional groups. One such example of these remarkable molecules are the sulfated steroid-amino acid conjugates known as polymastiamides A-F, isolated from the cold-water sponge Polymastia boletiformis collected at various locations along the Norwegian coast. Of these compounds, polymastiamide A (117) (Figure 26) has shown activity against plant pathogens Cladosporium cucumerinum and Pythium ultimum as well as human yeast pathogen C. albicans and antibacterial activity against $S$. aureus $[138,139]$.

\section{Triterpenoid Saponins}

Triterpenoid saponins are amphipathic glycosides that have one or more hydrophilic glycoside moieties combined with a lipophilic triterpene or steroid derivative, thus, their chemical class can be identified as triterpenoid glycosides. They are well-known as plant-derived allelochemicals, but they have also been obtained from marine organisms, in particular sea cucumbers, where they have been proposed as chemotaxonomic proxies $[227,228]$. Several bioactive properties have been reported 
from these compounds, including anti-feedant (repellents), antimicrobial and ichthyotoxic [229,230]. The term saponin derives from the soapwort plant (genus Saponaria family Caryophyllaceae), the root from which is used as a soap. Additionally, these triterpene conjugates produce a soap-like foam when shaken in aqueous solutions [230]. The amphipathic properties of saponins make them efficient surfactants, due to their capacity to interact with cell membrane components, e.g., cholesterol and phospholipids, and therefore, they are interesting for the development of cosmetics, drugs and nutraceuticals (nutrient absorption enhancers) [231]. Saponins are also readily soluble in water, and have been proposed as adjuvants, to dissolve active principles in the development of vaccines [232].<smiles>CC(/C=C/C=C(C)/C=C/C=C(C)/C=C/c1ccc(C(=O)O)c(C)c1C)=C\C=C\C(C)=C\C=C\c1ccc(C(=O)O)c(C)c1C</smiles><smiles>CC(C)=CCC/C(C)=C/CC/C(C)=C/CC/C(C)=C/CC/C(C)=C/CC/C(C)=C/CC/C(C)=C/CC/C(C)=C/Cc1c(C)c(O)c2ccccc2c1O</smiles><smiles>CC(/C=C/C=C(C)/C=C/C=C(C)/C=C/c1c(C)ccc(C)c1C)=C\C=C\C=C(C)\C=C\c1c(C)ccc(C)c1C</smiles>

Figure 25. Structures of several carotenoids obtained from Rhodococcus sp. B7740: (114) synechoxanthin, (115) dehydrogenated menaquinone and (116) isorenieratene.

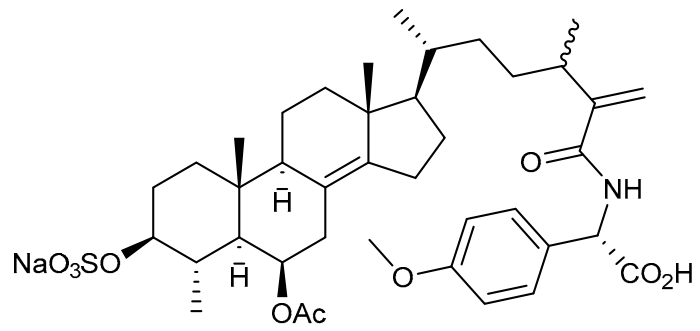

Polymastiamide A (117)

Figure 26. Structure of the triterpenoid conjugate compound (117) polymastiamide A from Polymastia boletiformis.

Two trisulfated triterpene glycosides, liouvillosides A (118) and B (119) (Figure 27), both virucidal against herpes simplex virus type 1 (HSV-1), were isolated from the Antarctic cucumarid sea cucumber Staurocucumis liouvillei, collected in South Georgia Islands [118].

The deep sea Arctic holothurian echinoderm Kolga hyalina collected at Amundsen Basin at 4352-4354 m depth was found to contain holothurinoside B (known from temperate holothurid species [233], as well as two novel triterpene holostane nonsulfated pentaosides, kolgaosides A (120) and B (121) (Figure 28), both possessing hemolytic activity against mouse erythrocytes, and mild inhibitory action against Ehrlich ascite carcinoma cells. All these triterpene glycosides are structurally close to achlioniceosides A1-A3 from the Antarctic sea cucumber Rhipidothuria racovitzai Hèrouard, 1901 (=Achlionice violaescupidata [234]), supporting a potential chemotaxonomic value [235]. 


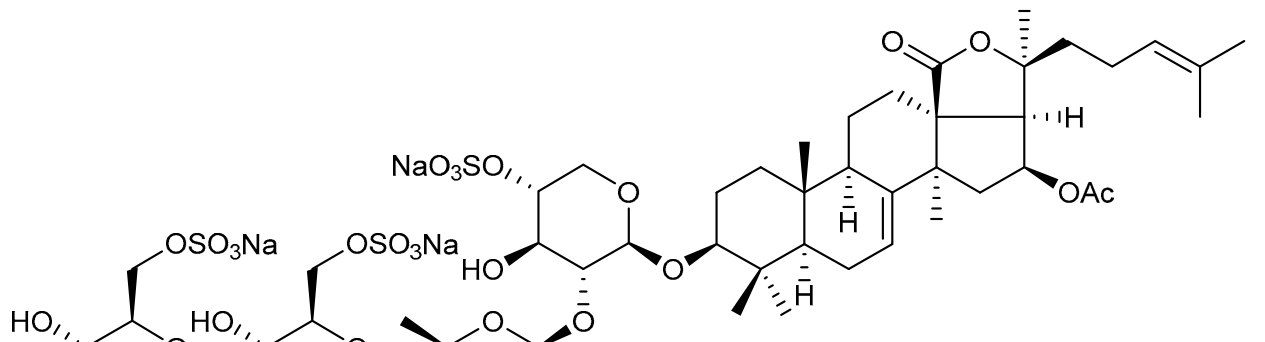

Liouvilloside A (118)<smiles>CC(C)(C)[13CH2][13CH3]</smiles>

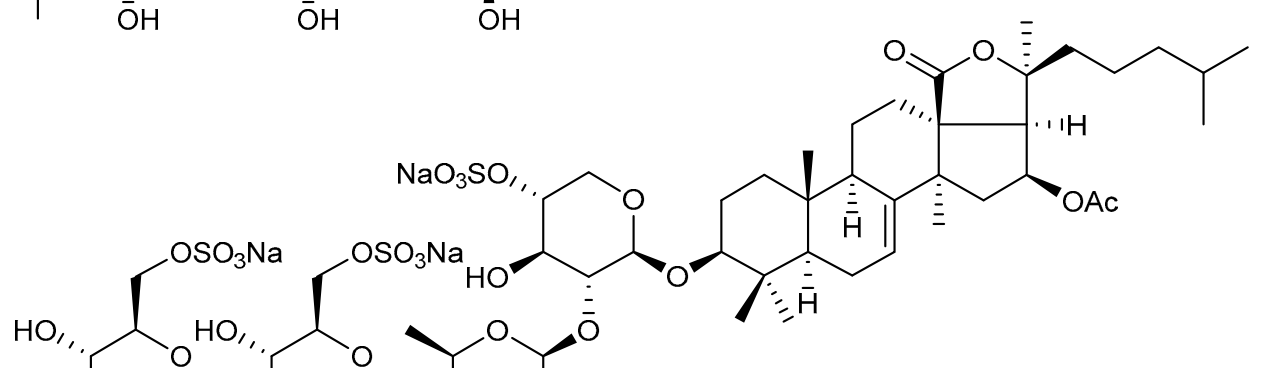<smiles>CO[C@H]1[C@@H](O)C(C)O[C@@H](O[C@H]2[C@@H](O)C(C)O[C@H](O[C@H]3[C@H](C)O[C@H](O)[C@@H](O)[C@@H]3O)[C@H]2O)[C@H]1O</smiles>

Figure 27. Structures of two triterpenoid saponin compounds $(118,119)$ liouvillosides A-B from Staurocucumis liouvillei.

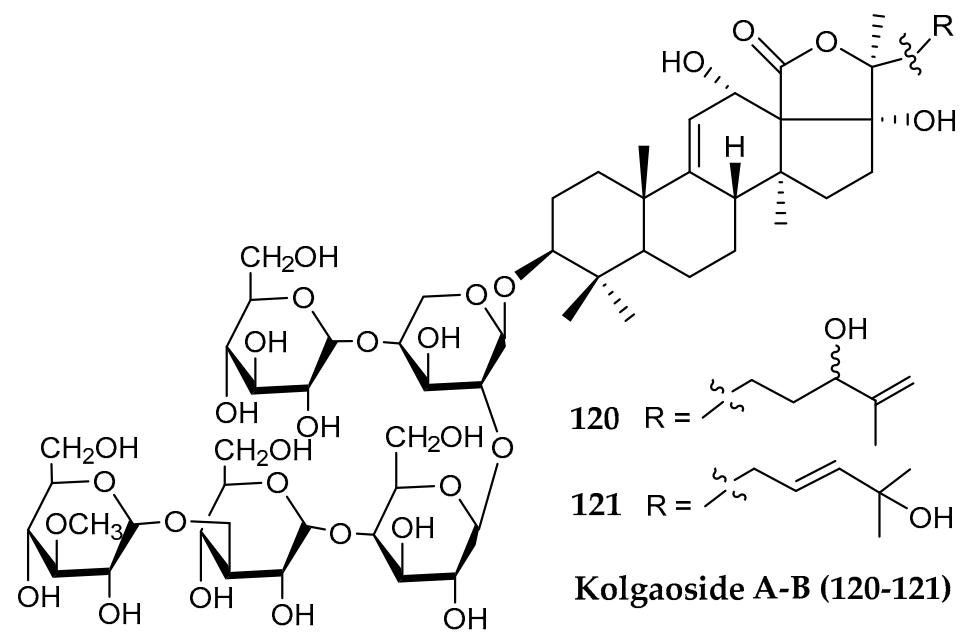

Figure 28. Structures of two triterpenoid glycoside compounds $(\mathbf{1 2 0}, \mathbf{1 2 1})$ kolgaosides A-B from Kolga hyalina.

\section{Meroterpenes}

Meroterpenes are molecules with a partial terpenoid structure attached to a shikimate-derived aromatic, usually a phenol, and are commonly found in marine ascidians, sponges and to a lesser extent in soft corals [236]. Bioactive meroterpenes featuring sesquiterpene moieties can also be found in organisms inhabiting the harsh polar regions. Tunicates in the genus Aplidium collected in the Ross Sea yielded rossinones A and B $(\mathbf{1 2 2}, \mathbf{1 2 3})$ (Figure 29), which displayed antiproliferative activity against several cell lines with $\mathrm{IC}_{50}$ values ranging from 0.084 to $30 \mu \mathrm{M}$ as well as selective antiviral activity against the DNA virus HSV-1 in addition to antibacterial and antifungal activity towards Bacillus subtilis and Trichophyton mentagrophytes [144]. 
<smiles>CC(C)=C[C@@H](O)C(=O)/C(C)=C/CC/C(C)=C/Cc1cc(O)ccc1O</smiles>

Rossinone A (122)

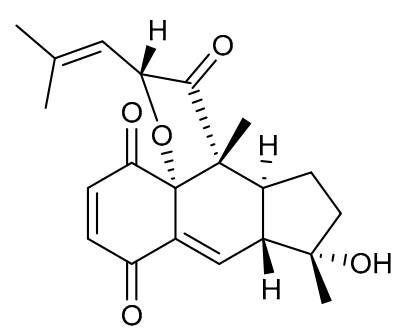

Rossinone B (123)<smiles>CC(=O)OCCCCCCC(C)=CCCC(C)=CCCC(C)=CCC=C(C)C(=O)O</smiles>

Figure 29. Structures of two meroterepenoid compounds, $(\mathbf{1 2 2}, \mathbf{1 2 3})$ rossinones A-B from Aplidium spp., and (124) menzoquinone from Desmarestia menziesii.

While the majority of compounds reported from polar marine algae are monoterpenes, bioactive diterpenoids in the form of meroterpenes such as menzoquinone (124) (Figure 29) have been isolated from Desmarestia menziesii, a commonly occurring brown algae that plays a major role in structuring the benthic ecosystems along the northern latitudes of the Western Antarctic Peninsula. This methylated diterpene-quinone bearing a carboxylic acid has shown antimicrobial activity against MRSA and VREF [155].

\section{Perspectives and Conclusions}

Bioprospecting is a complex issue as it embraces many fields, such as intellectual property rights, scientific research and exploitation of resources in an eco-friendly ethical manner [237-240]. Cooperation is needed to develop sustainable, respectful and appropriate access and benefit-sharing mechanisms for marine resources as well as the promotion of the participation by all states in international negotiations for encouraging innovation and greater equity [241-243].

Bioactive natural products from the sea are in this particular era are timely to develop drugs to fight against ever more frequent and contagious emerging pathogenic agents. One actual example is a potent antiviral molecule obtained from the ascidian Aplidium albicans, which is under clinical trials on infected humans with Corona Virus, similar to the 2020 pandemic SARS CoV-19 [244].

Marine organisms from the polar regions could greatly contribute to this growing repertoire of promising bioactive compounds. Indeed, extreme environments are important hot spots of microbial, metazoan and symbiotic cluster diversities, where selective forces have promoted the evolution of unique biosynthetic pathways for secondary metabolite production [14]. In the light of the publication record on molecules with pharmacological potential isolated up to date from Arctic and Antarctic marine taxa, terpene and terpenoid derivatives seem to be the most frequently reported [5]. Furthermore, these compound types often yield remarkable antimicrobial properties, including anti-viral and antitumoral activities. Such cytotoxic actions likely respond to detrimental effects driven by terpenoid products on the structure and function of microbial membranes and cell walls [245]. Therefore, natural bioactive terpenes and terpenoids, in these times of increasing incidence of emerging infectious diseases, antibiotic-resistance pathogenesis and cancer, represent a precious glimmer of hope for drug discovery. Bioprospecting of organisms inhabiting the polar environments has already led to the discovery of new bioactive molecules, mainly enzymes with potential commercial use for food, paper and textile industries [4]. It is thus expected that, in the near future, natural products from polar latitudes with an untapped biotechnological potential will also be included in health products to address upcoming epidemics, and disorders related to emerging and resistant infective vectors. 
Author Contributions: All authors contributed to the bibliography of the review and preparation of the final version of the manuscript. D.G. developed the original idea. L.N.-P., B.J.B. and D.G. organized all the materials. All authors have read and agreed to the published version of the manuscript

Funding: This study was funded by the Italian National Programme for Antarctic Research (PNRA) (2016/AZ1.06-Project PNRA16_00043 and 2016/AZ1.20-Project PNRA16_00128) and by CNR project Green\&CircularEconomy (FOE-2019, DBA.AD003.139). It was carried out in the framework of the SCAR Programme "Antarctic Thresholds-Ecosystem Resilience and Adaptation" (AnT-ERA).

Acknowledgments: D.G. wishes to thank Valentina Brasiello, Chiara Nobile and Giovanni Del Monaco for technical support and assistance.

Conflicts of Interest: The authors declare no conflict of interest.

\section{References}

1. Hurst, D.; Børresen, T.; Almesjö, L.; De Raedemaecker, F.; Bergseth, S. Marine Biotechnology Strategic Research and Innovation Roadmap: Insights to the Future Direction of European Marine Biotechnology; Marine Biotechnology ERA-NET: Oostende, Belgium, 2016.

2. Nunez-Pons, L.; Avila, C.; Romano, G.; Verde, C.; Giordano, D. UV-protective compounds in marine organisms from the Southern Ocean. Mar. Drugs 2018, 16, 336. [CrossRef] [PubMed]

3. Angulo-Preckler, C.; Spurkland, T.; Avila, C.; Iken, K. Antimicrobial activity of selected benthic Arctic invertebrates. Polar Biol. 2015, 38, 1941-1948. [CrossRef]

4. Bruno, S.; Coppola, D.; di Prisco, G.; Giordano, D.; Verde, C. Enzymes from marine polar regions and their biotechnological applications. Mar. Drugs 2019, 17, 544. [CrossRef] [PubMed]

5. Soldatou, S.; Baker, B.J. Cold-water marine natural products, 2006 to 2016. Nat. Prod. Rep. 2017, 34, 585-626. [CrossRef]

6. Tian, Y.; Li, Y.L.; Zhao, F.C. Secondary metabolites from polar organisms. Mar. Drugs 2017, 15, 28. [CrossRef]

7. Eakins, B.W.; Sharman, G.F. Volumes of the World's Oceans from ETOPO1; NOAA National Geophysical Data Center: Boulder, CO, USA, 2010.

8. Polyak, L.; Alley, R.B.; Andrews, J.T.; Brigham-Grette, J.; Cronin, T.M.; Darby, D.A.; Dyke, A.S.; Fitzpatrick, J.J.; Funder, S.; Holland, M.; et al. History of sea ice in the Arctic. Quat. Sci. Rev. 2010, 29, 1757-1778. [CrossRef]

9. Convey, P.; Bindschadler, R.; di Prisco, G.; Fahrbach, E.; Gutt, J.; Hodgson, D.A.; Mayewski, P.A.; Summerhayes, C.P.; Turner, J. Antarctic climate change and the environment. Antarct. Sci. 2009, 21, 541-563. [CrossRef]

10. Jayatilake, G.S.; Baker, B.J.; McClintock, J.B. Isolation and identification of a stilbene derivative from the Antarctic sponge Kirkpatrickia variolosa. J. Nat. Prod. 1995, 58, 1958-1960. [CrossRef]

11. Gordon, A. Oceanography of Antarctic Waters. In Antarctic Oceanology I; Reid, J.L., Ed.; AGU: Hoboken, NJ, USA, 1971; pp. 169-203.

12. Barker, P.F.; Filippelli, G.M.; Florindo, F.; Martin, E.E.; Scher, H.D. Onset and role of the Antarctic Circumpolar Current. Deep Sea Res. II Top. Stud. Ocean. 2007, 54, 2388-2398. [CrossRef]

13. Avila, C.; Taboada, S.; Núñez-Pons, L. Antarctic marine chemical ecology: What is next? Mar. Ecol. 2008, 29, 1-71. [CrossRef]

14. Núñez-Pons, L.; Avila, C. Natural products mediating ecological interactions in Antarctic benthic communities: A mini-review of the known molecules. Nat. Prod. Rep. 2015, 32, 1114-1130. [CrossRef] [PubMed]

15. Liu, J.T.; Lu, X.L.; Liu, X.Y.; Gao, Y.; Hu, B.; Jiao, B.H.; Zheng, H. Bioactive natural products from the antarctic and arctic organisms. Mini Rev. Med. Chem. 2013, 13, 617-626. [CrossRef] [PubMed]

16. Lebar, M.D.; Heimbegner, J.L.; Baker, B.J. Cold-water marine natural products. Nat. Prod. Rep. 2007, 24, 774-797. [CrossRef] [PubMed]

17. Klemm, E.J.; Wong, V.K.; Dougan, G. Emergence of dominant multidrug-resistant bacterial clades: Lessons from history and whole-genome sequencing. Proc. Nat. Acad. Sci. USA 2018, 115, 12872-12877. [CrossRef] [PubMed]

18. Martins, A.; Vieira, H.; Gaspar, H.; Santos, S. Marketed marine natural products in the pharmaceutical and cosmeceutical industries: Tips for success. Mar. Drugs 2014, 12, 1066-1101. [CrossRef] [PubMed]

19. Market Research Engine. Available online: https://www.marketresearchengine.com/marine-derived-drugsmarket (accessed on 15 May 2020).

20. Mayer, A.S.M. Marine Pharmaceuticals: The Clinical Pipeline. Available online: https://www.midwestern. edu/departments/marinepharmacology.xml (accessed on 27 July 2020).

21. Blunt, J.W.; Carroll, A.R.; Copp, B.R.; Davis, R.A.; Keyzers, R.A.; Prinsep, M.R. Marine natural products. Nat. Prod. Rep. 2018, 35, 8-53. [CrossRef] [PubMed] 
22. Jaspars, M.; De Pascale, D.; Andersen, J.H.; Reyes, F.; Crawford, A.D.; Ianora, A. The marine biodiscovery pipeline and ocean medicines of tomorrow. J. Mar. Biol. Assoc. U. K. 2016, 96, 151-158. [CrossRef]

23. Schoffski, P.; Dumez, H.; Wolter, P.; Stefan, C.; Wozniak, A.; Jimeno, J.; Van Oosterom, A.T. Clinical impact of trabectedin (ecteinascidin-743) in advanced/metastatic soft tissue sarcoma. Expert Opin. Pharm. 2008, 9, 1609-1618. [CrossRef]

24. Karsch-Mizrachi, I.; Takagi, T.; Cochrane, G.; International Nucleotide Sequence Database Collaboration. The international nucleotide sequence database collaboration. Nucleic Acids Res. 2018, 46, D48-D51. [CrossRef]

25. Costello, M.J.; Chaudhary, C. Marine biodiversity, biogeography, deep-sea gradients, and conservation. Curr. Biol. 2017, 27, R511-R527. [CrossRef]

26. Puig-Marcó, R. Access and benefit sharing of Antarctica's biological material. Mar. Genom. 2014, 17, 73-78. [CrossRef] [PubMed]

27. Dodds, K.J. Sovereignty watch: Claimant states, resources, and territory in contemporary Antarctica. Polar Rec. 2010, 47, 231-243. [CrossRef]

28. Petra, D.; Alex, G.O.E.; Bert, V.; Tamara, T. Marine genetic resources in areas beyond national jurisdiction: Access and benefit-sharing. Int. J. Mar. Coast. Law 2012, 27, 375-433. [CrossRef]

29. Dodds, K. Governing Antarctica: Contemporary challenges and the enduring legacy of the 1959 Antarctic Treaty. Glob. Policy 2010, 1, 108-115. [CrossRef]

30. Joyner, C.C. Bioprospecting as a challenge to the Antarctic Treaty. In Antarctic Security in the Twenty-First Century; Hemmings, A.D., Rothwell, D.R., Scott, K.N., Eds.; Routledge: Abingdon, UK, 2012; pp. 197-214.

31. Tvedt, M.W. Patent law and bioprospecting in Antarctica. Polar Rec. 2010, 47, 46-55. [CrossRef]

32. Rogan-Finnemore, M. What bioprospecting means for Antarctica and the Southern Ocean. In International Law Issues in the South Pacific; von Tigerstrom, B., Ed.; Ashgate: Hampshire, UK, 2005; pp. 199-228.

33. Summerhayes, C.P. International collaboration in Antarctica: The International Polar Years, the International Geophysical Year, and the Scientific Committee on Antarctic Research. Polar Rec. 2008, 44, 321-334. [CrossRef]

34. Oldham, P.; Hall, S.; Forero, O. Biological diversity in the patent system. PLoS ONE 2013, 8, e78737. [CrossRef]

35. Eritja, M.C. Bio-prospecting in the Arctic: An overview of the interaction between the rights of indigenous peoples and access and benefit sharing. Boston Coll. Environ. Aff. Law Rev. 2017, 44, 223.

36. Hoag, H. The cold rush. Nat. Biotech. 2009, 27, 690-692. [CrossRef]

37. Leary, D. UNU-IAS Report: Bioprospecting in the Arctic 8, 2008; UNU-IAS: Minato, Japan, 2013.

38. Carroll, A.R.; Copp, B.R.; Davis, R.A.; Keyzers, R.A.; Prinsep, M.R. Marine natural products. Nat. Prod. Rep. 2020, 37, 175-223. [CrossRef]

39. Alcaino, J.; Cifuentes, V.; Baeza, M. Physiological adaptations of yeasts living in cold environments and their potential applications. World J. Microbiol. Biotechnol. 2015, 31, 1467-1473. [CrossRef] [PubMed]

40. Munoz, P.A.; Marquez, S.L.; Gonzalez-Nilo, F.D.; Marquez-Miranda, V.; Blamey, J.M. Structure and application of antifreeze proteins from Antarctic bacteria. Microb. Cell Fact. 2017, 16, 138. [CrossRef] [PubMed]

41. Bang, J.K.; Lee, J.H.; Murugan, R.N.; Lee, S.G.; Do, H.; Koh, H.Y.; Shim, H.E.; Kim, H.C.; Kim, H.J. Antifreeze peptides and glycopeptides, and their derivatives: Potential uses in biotechnology. Mar. Drugs 2013, 11, 2013-2041. [CrossRef] [PubMed]

42. Venketesh, S.; Dayananda, C. Properties, potentials, and prospects of antifreeze proteins. Crit. Rev. Biotechnol. 2008, 28, 57-82. [CrossRef] [PubMed]

43. Qadeer, S.; Khan, M.A.; Ansari, M.S.; Rakha, B.A.; Ejaz, R.; Iqbal, R.; Younis, M.; Ullah, N.; DeVries, A.L.; Akhter, S. Efficiency of antifreeze glycoproteins for cryopreservation of Nili-Ravi (Bubalus bubalis) buffalo bull sperm. Anim. Reprod. Sci. 2015, 157, 56-62. [CrossRef] [PubMed]

44. Lee, S.G.; Koh, H.Y.; Lee, J.H.; Kang, S.H.; Kim, H.J. Cryopreservative effects of the recombinant ice-binding protein from the arctic yeast Leucosporidium sp. on red blood cells. Appl. Biochem. Biotechnol. 2012, 167, 824-834. [CrossRef]

45. Kumar, A.S.; Mody, K.; Jha, B. Bacterial exopolysaccharides-A perception. J. Basic Microbiol. 2007, 47, $103-117$. [CrossRef]

46. Freitas, F.; Alves, V.D.; Reis, M.A. Advances in bacterial exopolysaccharides: From production to biotechnological applications. Trends Biotechnol. 2011, 29, 388-398. [CrossRef]

47. Caruso, C.; Rizzo, C.; Mangano, S.; Poli, A.; Di Donato, P.; Nicolaus, B.; Di Marco, G.; Michaud, L.; Lo Giudice, A. Extracellular polymeric substances with metal adsorption capacity produced by Pseudoalteromonas sp. MER144 from Antarctic seawater. Environ. Sci. Pollut. Res. Int. 2018, 25, 4667-4677. [CrossRef] 
48. Poli, A.; Anzelmo, G.; Nicolaus, B. Bacterial exopolysaccharides from extreme marine habitats: Production, characterization and biological activities. Mar. Drugs 2010, 8, 1779-1802. [CrossRef]

49. Bianchi, A.C.; Olazabal, L.; Torre, A.; Loperena, L. Antarctic microorganisms as source of the omega-3 polyunsaturated fatty acids. World J. Microbiol. Biotechnol. 2014, 30, 1869-1878. [CrossRef] [PubMed]

50. Xue, Z.; Sharpe, P.L.; Hong, S.P.; Yadav, N.S.; Xie, D.; Short, D.R.; Damude, H.G.; Rupert, R.A.; Seip, J.E.; Wang, J.; et al. Production of omega-3 eicosapentaenoic acid by metabolic engineering of Yarrowia lipolytica. Nat. Biotechnol. 2013, 31, 734-740. [CrossRef]

51. Abbas, S.; Kelly, M.; Bowling, J.; Sims, J.; Waters, A.; Hamann, M. Advancement into the Arctic region for bioactive sponge secondary metabolites. Mar. Drugs 2011, 9, 2423-2437. [CrossRef] [PubMed]

52. Hansen, Ø.K.; Isaksson, J.; Glomsaker, E.; Andersen, H.J.; Hansen, E. Ponasterone A and F, ecdysteroids from the Arctic bryozoan Alcyonidium gelatinosum. Molecules 2018, 23, 1481. [CrossRef]

53. Di, X.; Rouger, C.; Hardardottir, I.; Freysdottir, J.; Molinski, T.F.; Tasdemir, D.; Omarsdottir, S. 6-Bromoindole derivatives from the Icelandic marine sponge Geodia barretti: Isolation and anti-inflammatory activity. Mar. Drugs 2018, 16, 437. [CrossRef]

54. Figuerola, B.; Sala-Comorera, L.; Angulo-Preckler, C.; Vazquez, J.; Jesus Montes, M.; Garcia-Aljaro, C.; Mercade, E.; Blanch, A.R.; Avila, C. Antimicrobial activity of Antarctic bryozoans: An ecological perspective with potential for clinical applications. Mar. Environ. Res. 2014, 101, 52-59. [CrossRef] [PubMed]

55. Berne, S.; Kalauz, M.; Lapat, M.; Savin, L.; Janussen, D.; Kersken, D.; Avguštin, J.A.; Jokhadar, Š.Z.; Jaklič, D.; Gunde-Cimerman, N.; et al. Screening of the Antarctic marine sponges (Porifera) as a source of bioactive compounds. Polar Biol. 2016, 39, 947-959. [CrossRef]

56. Moles, J.; Nunez-Pons, L.; Taboada, S.; Figueroa, B.; Cristobo, J.; Avila, C. Anti-predatory chemical defences in Antarctic benthic fauna. Mar. Biol. 2015, 162, 1813-1821. [CrossRef]

57. Li, F.; Janussen, D.; Peifer, C.; Perez-Victoria, I.; Tasdemir, D. Targeted isolation of tsitsikammamines from the Antarctic deep-sea sponge Latrunculia biformis by molecular networking and anticancer activity. Mar. Drugs 2018, 16, 268. [CrossRef]

58. Thomas, T.R.; Kavlekar, D.P.; LokaBharathi, P.A. Marine drugs from sponge-microbe association-A review. Mar. Drugs 2010, 8, 1417-1468. [CrossRef]

59. Blockley, A.; Elliott, D.; Roberts, A.P.; Sweet, M. Symbiotic microbes from marine invertebrates: Driving a new era of natural product drug discovery. Div. Distrib. 2017, 9, 49. [CrossRef]

60. Lo Giudice, A.; Rizzo, C. Bacteria associated with marine benthic invertebrates from polar environments: Unexplored frontiers for biodiscovery? Diversity 2018, 10, 80. [CrossRef]

61. Furbino, L.E.; Godinho, V.M.; Santiago, I.F.; Pellizari, F.M.; Alves, T.M.; Zani, C.L.; Junior, P.A.; Romanha, A.J.; Carvalho, A.G.; Gil, L.H.; et al. Diversity patterns, ecology and biological activities of fungal communities associated with the endemic macroalgae across the Antarctic peninsula. Microb. Ecol. 2014, 67, 775-787. [CrossRef]

62. Henríquez, M.; Vergara, K.; Norambuena, J.; Beiza, A.; Maza, F.; Ubilla, P.; Araya, I.; Chávez, R.; San-Martín, A.; Darias, J.; et al. Diversity of cultivable fungi associated with Antarctic marine sponges and screening for their antimicrobial, antitumoral and antioxidant potential. World J. Microbiol. Biotech. 2014, 30, 65-76. [CrossRef] [PubMed]

63. Godinho, V.M.; Furbino, L.E.; Santiago, I.F.; Pellizzari, F.M.; Yokoya, N.S.; Pupo, D.; Alves, T.M.; Junior, P.A.; Romanha, A.J.; Zani, C.L.; et al. Diversity and bioprospecting of fungal communities associated with endemic and cold-adapted macroalgae in Antarctica. ISME J. 2013, 7, 1434-1451. [CrossRef]

64. Maida, I.; Bosi, E.; Fondi, M.; Perrin, E.; Orlandini, V.; Papaleo, M.; Mengoni, A.; de Pascale, D.; Tutino, M.L.; Michaud, L.; et al. Antimicrobial activity of Pseudoalteromonas strains isolated from the Ross Sea (Antarctica) versus Cystic Fibrosis opportunistic pathogens. Hydrobiologia 2015, 761, 443-457. [CrossRef]

65. Jayatilake, G.S.; Thornton, M.P.; Leonard, A.C.; Grimwade, J.E.; Baker, B.J. Metabolites from an Antarctic sponge-associated bacterium, Pseudomonas aeruginosa. J. Nat. Prod. 1996, 59, 293-296. [CrossRef]

66. Mangano, S.; Michaud, L.; Caruso, C.; Brilli, M.; Bruni, V.; Fani, R.; Lo Giudice, A. Antagonistic interactions between psychrotrophic cultivable bacteria isolated from Antarctic sponges: A preliminary analysis. Res. Microbiol. 2009, 160, 27-37. [CrossRef]

67. Orlandini, V.; Maida, I.; Fondi, M.; Perrin, E.; Papaleo, M.C.; Bosi, E.; de Pascale, D.; Tutino, M.L.; Michaud, L.; Lo Giudice, A.; et al. Genomic analysis of three sponge-associated Arthrobacter Antarctic strains, inhibiting the growth of Burkholderia cepacia complex bacteria by synthesizing volatile organic compounds. Microbiol. Res. 2014, 169, 593-601. [CrossRef] 
68. Papaleo, M.C.; Fondi, M.; Maida, I.; Perrin, E.; Lo Giudice, A.; Michaud, L.; Mangano, S.; Bartolucci, G.; Romoli, R.; Fani, R. Sponge-associated microbial Antarctic communities exhibiting antimicrobial activity against Burkholderia cepacia complex bacteria. Biotechnol. Adv. 2012, 30, 272-293. [CrossRef]

69. Papaleo, M.C.; Romoli, R.; Bartolucci, G.; Maida, I.; Perrin, E.; Fondi, M.; Orlandini, V.; Mengoni, A.; Emiliani, G.; Tutino, M.L.; et al. Bioactive volatile organic compounds from Antarctic (sponges) bacteria. New Biotechnol. 2013, 30, 824-838. [CrossRef] [PubMed]

70. Tedesco, P.; Maida, I.; Palma Esposito, F.; Tortorella, E.; Subko, K.; Ezeofor, C.C.; Zhang, Y.; Tabudravu, J.; Jaspars, M.; Fani, R.; et al. Antimicrobial activity of monoramnholipids produced by bacterial strains isolated from the Ross Sea (Antarctica). Mar. Drugs 2016, 14, 83. [CrossRef] [PubMed]

71. Wietz, M.; Månsson, M.; Bowman, J.S.; Blom, N.; Ng, Y.; Gram, L. Wide distribution of closely related, antibiotic-producing Arthrobacter strains throughout the Arctic Ocean. Appl. Environ. Microbiol. 2012, 78, 2039-2042. [CrossRef] [PubMed]

72. Gao, X.; Lu, Y.; Xing, Y.; Ma, Y.; Lu, J.; Bao, W.; Wang, Y.; Xi, T. A novel anticancer and antifungus phenazine derivative from a marine actinomycete BM-17. Microbiol. Res. 2012, 167, 616-622. [CrossRef] [PubMed]

73. Zhang, H.; Saurav, K.; Yu, Z.; Mándi, A.; Kurtán, T.; Li, J.; Tian, X.; Zhang, Q.; Zhang, W.; Zhang, C. $\alpha$-Pyrones with diverse hydroxy substitutions from three marine-derived Nocardiopsis strains. J. Nat. Prod. 2016, 79, 1610-1618. [CrossRef] [PubMed]

74. Chen, Y.; Xie, B.; Yang, J.; Chen, J.; Sun, Z. Identification of microbial carotenoids and isoprenoid quinones from Rhodococcus sp. B7740 and its stability in the presence of iron in model gastric conditions. Food Chem. 2018, 240, 204-211. [CrossRef]

75. Chen, Y.; Guo, M.; Yang, J.; Chen, J.; Xie, B.; Sun, Z. Potential TSPO ligand and photooxidation quencher isorenieratene from Arctic Ocean Rhodococcus sp. B7740. Mar. Drugs 2019, 17, 316. [CrossRef]

76. Chen, Y.; Mu, Q.; Hu, K.; Chen, M.; Yang, J.; Chen, J.; Xie, B.; Sun, Z. Characterization of MK(8) $(\mathrm{H}(2))$ from Rhodococcus sp. B7740 and its potential antiglycation capacity measurements. Mar. Drugs 2018, 16, 391. [CrossRef]

77. Moon, K.; Ahn, C.-H.; Shin, Y.; Won, T.H.; Ko, K.; Lee, S.K.; Oh, K.-B.; Shin, J.; Nam, S.-I.; Oh, D.-C. New benzoxazine secondary metabolites from an Arctic Actinomycete. Mar. Drugs 2014, 12, 2526-2538. [CrossRef]

78. Ivanova, V.; Oriol, M.; Montes, M.-J.; Garcia, A.; Guinea, J. Secondary metabolites from a Streptomyces strain isolated from Livingston Island, Antarctica. Z. Naturforsch. C Biosci. 2001, 56, 1-5. [CrossRef]

79. Kim, D.; Lee, E.J.; Lee, J.; Leutou, A.S.; Shin, Y.H.; Choi, B.; Hwang, J.S.; Hahn, D.; Choi, H.; Chin, J.; et al. Antartin, a cytotoxic zizaane-type sesquiterpenoid from a Streptomyces sp. isolated from an Antarctic marine sediment. Mar. Drugs 2018, 16, 130. [CrossRef] [PubMed]

80. Macherla, V.R.; Liu, J.; Bellows, C.; Teisan, S.; Nicholson, B.; Lam, K.S.; Potts, B.C.M. Glaciapyrroles A, B, and $\mathrm{C}$, pyrrolosesquiterpenes from a Streptomyces sp. isolated from an Alaskan marine sediment. J. Nat. Prod. 2005, 68, 780-783. [CrossRef] [PubMed]

81. Sannino, F.; Parrilli, E.; Apuzzo, G.A.; de Pascale, D.; Tedesco, P.; Maida, I.; Perrin, E.; Fondi, M.; Fani, R.; Marino, G.; et al. Pseudoalteromonas haloplanktis produces methylamine, a volatile compound active against Burkholderia cepacia complex strains. New Biotechnol. 2017, 35, 13-18. [CrossRef]

82. Sannino, F.; Sansone, C.; Galasso, C.; Kildgaard, S.; Tedesco, P.; Fani, R.; Marino, G.; de Pascale, D.; Ianora, A.; Parrilli, E.; et al. Pseudoalteromonas haloplanktis TAC125 produces 4-hydroxybenzoic acid that induces pyroptosis in human A459 lung adenocarcinoma cells. Sci. Rep. 2018, 8, 1190. [CrossRef]

83. Mitova, M.; Tutino, M.L.; Infusini, G.; Marino, G.; De Rosa, S. Exocellular peptides from Antarctic psychrophile Pseudoalteromonas Haloplanktis. Mar. Biotechnol. 2005, 7, 523-531. [CrossRef] [PubMed]

84. Casillo, A.; Papa, R.; Ricciardelli, A.; Sannino, F.; Ziaco, M.; Tilotta, M.; Selan, L.; Marino, G.; Corsaro, M.M.; Tutino, M.L.; et al. Anti-biofilm activity of a long-chain fatty aldehyde from Antarctic Pseudoalteromonas haloplanktis TAC125 against Staphylococcus epidermidis biofilm. Front. Cell. Infect. Microb. 2017, 7, 46. [CrossRef] [PubMed]

85. Chianese, G.; Esposito, F.P.; Parrot, D.; Ingham, C.; de Pascale, D.; Tasdemir, D. Linear aminolipids with moderate antimicrobial activity from the Antarctic gram-negative bacterium Aequorivita sp. Mar. Drugs 2018, 16, 187. [CrossRef]

86. Al-Zereini, W.; Schuhmann, I.; Laatsch, H.; Helmke, E.; Anke, H. New aromatic nitro compounds from Salegentibacter sp. T436, an Arctic sea ice bacterium: Taxonomy, fermentation, isolation and biological activities. J. Antibiot. 2007, 60, 301-308. [CrossRef] 
87. Schuhmann, I.; Yao, C.B.F.-F.; Al-Zereini, W.; Anke, H.; Helmke, E.; Laatsch, H. Nitro derivatives from the Arctic ice bacterium Salegentibacter sp. isolate T436. J. Antibiot. 2009, 62, 453-460. [CrossRef]

88. Zhang, H.L.; Hua, H.M.; Pei, Y.H.; Yao, X.S. Three new cytotoxic cyclic acylpeptides from marine Bacillus sp. Chem. Pharm. Bull. 2004, 52, 1029-1030. [CrossRef]

89. Corral, P.; Esposito, F.P.; Tedesco, P.; Falco, A.; Tortorella, E.; Tartaglione, L.; Festa, C.; D'Auria, M.V.; Gnavi, G.; Varese, G.C.; et al. Identification of a sorbicillinoid-producing Aspergillus strain with antimicrobial activity against Staphylococcus aureus: A new polyextremophilic marine fungus from Barents Sea. Mar. Biotechnol. 2018, 20, 502-511. [CrossRef] [PubMed]

90. Wu, G.W.; Lin, A.Q.; Gu, Q.Q.; Zhu, T.J.; Li, D.H. Four new chloro-eremophilane sesquiterpenes from an Antarctic deep-sea derived fungus, Penicillium sp PR19N-1. Mar. Drugs 2013, 11, 1399-1408. [CrossRef] [PubMed]

91. Lin, A.; Wu, G.; Gu, Q.; Zhu, T.; Li, D. New eremophilane-type sesquiterpenes from an Antarctic deepsea derived fungus, Penicillium sp. PR19 N-1. Arch. Pharm. Res. 2014, 37, 839-844. [CrossRef]

92. Niu, S.; Fan, Z.-W.; Xie, C.-L.; Liu, Q.; Luo, Z.-H.; Liu, G.; Yang, X.-W. Spirograterpene A, a tetracyclic spiro-diterpene with a fused 5/5/5/5 ring system from the deep-sea-derived fungus Penicillium granulatum MCCC 3A00475. J. Nat. Prod. 2017, 80, 2174-2177. [CrossRef] [PubMed]

93. Zhou, Y.; Li, Y.H.; Yu, H.B.; Liu, X.Y.; Lu, X.L.; Jiao, B.H. Furanone derivative and sesquiterpene from Antarctic marine-derived fungus Penicillium sp. S-1-18. J. Asian Nat. Prod. Res. 2018, 20, 1108-1115. [CrossRef]

94. Hu, Z.-Y.; Li, Y.-Y.; Huang, Y.-J.; Su, W.-J.; Shen, Y.-M. Three new sesquiterpenoids from Xylaria sp. NCY2. Helv. Chim. Acta 2008, 91, 46-52. [CrossRef]

95. Wu, G.W.; Ma, H.Y.; Zhu, T.J.; Li, J.; Gu, Q.Q.; Li, D.H. Penilactones A and B, two novel polyketides from Antarctic deep-sea derived fungus Penicillium crustosum PRB-2. Tetrahedron 2012, 68, 9745-9749. [CrossRef]

96. Wu, B.; Wiese, J.; Labes, A.; Kramer, A.; Schmaljohann, R.; Imhoff, J.F. Lindgomycin, an unusual antibiotic polyketide from a marine fungus of the Lindgomycetaceae. Mar. Drugs 2015, 13, 4617-4632. [CrossRef]

97. Shin, H.J.; Mondol, M.A.M.; Yu, T.K.; Lee, H.-S.; Lee, Y.-J.; Jung, H.J.; Kim, J.H.; Kwon, H.J. An angiogenesis inhibitor isolated from a marine-derived actinomycete, Nocardiopsis sp. 03N67. Phytochem. Lett. 2010, 3, 194-197. [CrossRef]

98. Silva, T.R.; Canela-Garayoa, R.; Eras, J.; Rodrigues, M.V.N.; Dos Santos, F.N.; Eberlin, M.N.; Neri-Numa, I.A.; Pastore, G.M.; Tavares, R.S.N.; Debonsi, H.M.; et al. Pigments in an iridescent bacterium, Cellulophaga fucicola, isolated from Antarctica. Antonie Leeuwenhoek 2019, 112, 479-490. [CrossRef]

99. Silva, T.R.; Tavares, R.S.N.; Canela-Garayoa, R.; Eras, J.; Rodrigues, M.V.N.; Neri-Numa, I.A.; Pastore, G.M.; Rosa, L.H.; Schultz, J.A.A.; Debonsi, H.M.; et al. Chemical characterization and biotechnological applicability of pigments i solated from Antarctic bacteria. Mar. Biotechnol. 2019, 21, 416-429. [CrossRef] [PubMed]

100. Figueroa, L.; Jiménez, C.; Rodríguez, J.; Areche, C.; Chávez, R.; Henríquez, M.; de la Cruz, M.; Díaz, C.; Segade, Y.; Vaca, I. 3-Nitroasterric acid derivatives from an Antarctic sponge-derived Pseudogymnoascus sp. fungus. J. Nat. Prod. 2015, 78, 919-923. [CrossRef] [PubMed]

101. Kim, D.-C.; Lee, H.-S.; Ko, W.; Lee, D.-S.; Sohn, J.H.; Yim, J.H.; Kim, Y.-C.; Oh, H. Anti-inflammatory effect of methylpenicinoline from a marine isolate of Penicillium sp. (SF-5995): Inhibition of NF- $\mathrm{B}$ and MAPK pathways in lipopolysaccharide-induced RAW264.7 macrophages and BV2 microglia. Molecules 2014, 19, 18073-18089. [CrossRef] [PubMed]

102. Manzo, E.; Ciavatta, M.L.; Melck, D.; Schupp, P.; de Voogd, N.; Gavagnin, M. Aromatic cyclic peroxides and related keto-compounds from the Plakortis sp. component of a sponge consortium. J. Nat. Prod. 2009, 72, 1547-1551. [CrossRef] [PubMed]

103. Carbone, M.; Núñez-Pons, L.; Castelluccio, F.; Avila, C.; Gavagnin, M. Illudalane sesquiterpenoids of the alcyopterosin series from the Antarctic marine soft coral Alcyonium grandis. J. Nat. Prod. 2009, 72, 1357-1360. [CrossRef]

104. Palermo, J.A.; Brasco, M.F.; Spagnuolo, C.; Seldes, A.M. Illudalane sesquiterpenoids from the soft coral Alcyonium paessleri: The first natural nitrate esters. J. Org. Chem. 2000, 65, 4482-4486. [CrossRef]

105. Brasco, M.F.R.; Seldes, A.M.; Palermo, J.A. Paesslerins A and B: Novel tricyclic sesquiterpenoids from the soft coral Alcyonium paessleri. Org. Lett. 2001, 3, 1415-1417. [CrossRef]

106. Mellado, G.G.; Zubia, E.; Ortega, M.J.; Lopez-Gonzalez, P.J. Steroids from the Antarctic octocoral Anthomastus bathyproctus. J. Nat. Prod. 2005, 68, 1111-1115. [CrossRef]

107. Thomas, S.A.L.; Sanchez, A.; Kee, Y.; Wilson, N.G.; Baker, B.J. Bathyptilones: Terpenoids from an Antarctic sea pen, Anthoptilum grandiflorum (Verrill, 1879). Mar. Drugs 2019, 17, 513. [CrossRef] 
108. Mellado, G.G.; Zubia, E.; Ortega, M.J.; Lopez-Gonzalez, P.J. New polyoxygenated steroids from the Antarctic octocoral Dasystenella Acanthina. Steroids 2004, 69, 291-299. [CrossRef]

109. Koljak, R.; Lopp, A.; Pehk, T.; Varvas, K.; Muurisepp, A.-M.; Jarving, I.; Samel, N. New cytotoxic sterols from the soft coral Gersemia fruticosa. Tetrahedron 1998, 54, 179-186. [CrossRef]

110. Lopp, A.; Pihlak, A.; Paves, H.; Samuel, K.; Koljak, R.; Samel, N. The effect of 9,11-secosterol, a newly discovered compound from the soft coral Gersemia fruticosa, on the growth and cell cycle progression of various tumor cells in culture. Steroids 1994, 59, 274-281. [CrossRef]

111. Angulo-Preckler, C.; Genta-Jouve, G.; Mahajan, N.; de la Cruz, M.; de Pedro, N.; Reyes, F.; Iken, K.; Avila, C.; Thomas, O.P. Gersemiols A-C and eunicellol A, diterpenoids from the Arctic soft coral Gersemia fruticosa. J. Nat. Prod. 2016, 79, 1132-1136. [CrossRef]

112. Thomas, S.A.L.; von Salm, J.L.; Clark, S.; Nemani, P.; Ferlita, S.; Wilson, N.G.; Baker, B.J. Keikipukalides, furanocembranoid aldehydes from the deep sea Antarctic coral Plumerella delicatissima. J. Nat. Prod. 2018, 81, 117-123. [CrossRef] [PubMed]

113. Von Salm, J.L.; Wilson, N.G.; Vesely, B.A.; Kyle, D.E.; Cuce, J.; Baker, B.J. Shagenes A and B, new tricyclic sesquiterpenes produced by an undescribed Antarctic octocoral. Org. Lett. 2014, 16, 2630-2633. [CrossRef] [PubMed]

114. Tadesse, M.; Tabudravu, J.N.; Jaspars, M.; Strom, M.B.; Hansen, E.; Andersen, J.H.; Kristiansen, P.E.; Haug, T. The antibacterial ent-eusynstyelamide B and eusynstyelamides D, E, and F from the Arctic bryozoan Tegella cf. spitzbergensis. J. Nat. Prod. 2011, 74, 837-841. [CrossRef]

115. Michael, P.; Hansen, E.; Isaksson, J.; Andersen, J.H.; Hansen, K.Ø. Dendrobeaniamine A, a new alkaloid from the Arctic marine bryozoan Dendrobeania murrayana. Nat. Prod. Res. 2019, 34, 2059-2064. [CrossRef]

116. Maschek, J.A.; Mevers, E.M.; Diyabalanage, T.; Chen, L.; Ren, Y.; Amsler, C.D.; McClintock, J.B.; Wu, J.; Baker, B.J. Palmadorin chemodiversity from the Antarctic nudibranch Austrodoris kerguelenensis and inhibition of Jak2/STAT5-dependent HEL leukemia cells. Tetrahedron 2012, 68, 9095-9104. [CrossRef]

117. Rodriguez, J.; Castro, R.; Riguera, R. Holothurinosides: New antitumour non-sulphated triterpenoid glycosides from the sea cucumber Holothuria forskalii. Tetrahedron 1991, 47, 4753-4762. [CrossRef]

118. Maier, M.S.; Roccatagliata, A.J.; Kuriss, A.; Chludil, H.; Seldes, A.M.; Pujol, C.A.; Damonte, E.B. Two new cytotoxic and virucidal trisulfated triterpene glycosides from the Antarctic sea cucumber Staurocucumis liouvillei. J. Nat. Prod. 2001, 64, 732-736. [CrossRef]

119. Kicha, A.A.; Ivanchina, N.V.; Malyarenko, T.V.; Kalinovsky, A.I.; Popov, R.S.; Stonik, V.A. Six new polyhydroxylated steroids conjugated with taurine, microdiscusols A-F, from the Arctic starfish Asterias microdiscus. Steroids 2019, 150, 108458. [CrossRef]

120. D'Auria, M.V.; Paloma, L.G.; Minale, L.; Riccio, R.; Zampella, A.; Morbidoni, M. Isolation and structure characterization of two novel bioactive sulphated polyhydroxysteroids from the Antarctic ophiuroid Ophioderma longicaudum. Nat. Prod. Lett. 1993, 3, 197-201. [CrossRef]

121. Comin, M.J.; Maier, M.S.; Roccatagliata, A.J.; Pujol, C.A.; Damonte, E.B. Evaluation of the antiviral activity of natural sulfated polyhydroxysteroids and their synthetic derivatives and analogs. Steroids 1999, 64, 335-340. [CrossRef]

122. Ma, W.S.; Mutka, T.; Vesley, B.; Amsler, M.O.; McClintock, J.B.; Amsler, C.D.; Perman, J.A.; Singh, M.P.; Maiese, W.M.; Zaworotko, M.J.; et al. Norselic acids A-E, highly oxidized anti-infective steroids that deter mesograzer predation, from the Antarctic sponge Crella sp. J. Nat. Prod. 2009, 72, 1842-1846. [CrossRef] [PubMed]

123. Ankisetty, S.; Amsler, C.D.; McClintock, J.B.; Baker, B.J. Further membranolide diterpenes from the antarctic sponge Dendrilla membranosa. J. Nat. Prod. 2004, 67, 1172-1174. [CrossRef] [PubMed]

124. Shilling, A.J.; Witowski, C.G.; Maschek, J.A.; Azhari, A.; Vesely, B.; Kyle, D.E.; Amsler, C.D.; McClintock, J.B.; Baker, B.J. Spongian diterpenoids derived from the Antarctic sponge Dendrilla antarctica are potent inhibitors of the Leishmania parasite. J. Nat. Prod. 2020, 83, 1553-1562. [CrossRef]

125. Von Salm, J.L.; Witowski, C.G.; Fleeman, R.M.; McClintock, J.B.; Amsler, C.D.; Shaw, L.N.; Baker, B.J. Darwinolide, a new diterpene scaffold thati inhibits methicillin-resistant Staphylococcus aureus biofilm from the Antarctic sponge Dendrilla membranosa. Org. Lett. 2016, 18, 2596-2599. [CrossRef]

126. Bory, A.; Shilling, A.J.; Allen, J.; Azhari, A.; Roth, A.; Shaw, L.N.; Kyle, D.E.; Adams, J.H.; Amsler, C.D.; McClintock, J.B.; et al. Bioactivity of spongian diterpenoid scaffolds from the Antarctic sponge Dendrilla Antarctica. Mar. Drugs. 2020, 18, 327. [CrossRef] 
127. Ciaglia, E.; Malfitano, A.M.; Laezza, C.; Fontana, A.; Nuzzo, G.; Cutignano, A.; Abate, M.; Pelin, M.; Sosa, S.; Bifulco, M.; et al. Immuno-modulatory and anti-inflammatory effects of dihydrogracilin A, a terpene derived from the marine sponge Dendrilla membranosa. Int. J. Mol. Sci. 2017, 18, 1643. [CrossRef]

128. Lidgren, G.; Bohlin, L.; Bergman, J. Studies of Swedish marine organisms. VII. A novel biologically active indole alkaloid from the sponge Geodia baretti. Tetrahedron Lett. 1986, 27, 3283-3284. [CrossRef]

129. Lind, K.F.; Hansen, E.; Østerud, B.; Eilertsen, K.-E.; Bayer, A.; Engqvist, M.; Leszczak, K.; Jørgensen, T.Ø.; Andersen, J.H. Antioxidant and anti-inflammatory activities of barettin. Mar. Drugs 2013, 11, 2655-2666. [CrossRef] [PubMed]

130. Volk, C.A.; Koeck, M. Viscosaline: New 3-alkyl pyridinium alkaloid from the Arctic sponge Haliclona viscosa. Org. Biomol. Chem. 2004, 2, 1827-1830. [CrossRef] [PubMed]

131. Lippert, H.; Brinkmeyer, R.; Mulhaupt, T.; Iken, K. Antimicrobial activity in sub-Arctic marine invertebrates. Polar Biol. 2003, 26, 591-600. [CrossRef]

132. Perry, N.B.; Ettouati, L.; Litaudon, M.; Blunt, J.W.; Munro, M.H.G.; Parkin, S.; Hope, H. Alkaloids from the antarctic sponge Kirkpatrickia varialosa. Part 1: Variolin B, a new antitumor and antiviral compound. Tetrahedron 1994, 50, 3987-3992. [CrossRef]

133. Trimurtulu, G.; Faulkner, D.J.; Perry, N.B.; Ettouati, L.; Litaudon, M.; Blunt, J.W.; Munro, M.H.G.; Jameson, G.B. Alkaloids from the antarctic sponge Kirkpatrickia varialosa. Part 2: Variolin A and N(3')-methyl tetrahydrovariolin B. Tetrahedron 1994, 50, 3993-4000. [CrossRef]

134. Na, M.; Ding, Y.; Wang, B.; Tekwani, B.L.; Schinazi, R.F.; Franzblau, S.; Kelly, M.; Stone, R.; Li, X.-C.; Ferreira, D.; et al. Anti-infective discorhabdins from a deep-water Alaskan sponge of the senus Latrunculia. J. Nat. Prod. 2010, 73, 383-387. [CrossRef]

135. Cutignano, A.; De Palma, R.; Fontana, A. A chemical investigation of the Antarctic sponge Lyssodendoryx flabellata. Nat. Prod. Res. 2012, 26, 1240-1248. [CrossRef]

136. Cutignano, A.; Nuzzo, G.; D’Angelo, D.; Borbone, E.; Fusco, A.; Fontana, A. Mycalol: A natural lipid with promising cytotoxic properties against human anaplastic thyroid carcinoma cells. Angew. Chem. Int. Ed. 2013, 52, 9256-9260. [CrossRef]

137. Holzwarth, M.; Trendel, J.-M.; Albrecht, P.; Maier, A.; Michaelis, W. Cyclic peroxides derived from the marine sponge Plakortis simplex. J. Nat. Prod. 2005, 68, 759-761. [CrossRef]

138. Kong, F.; Andersen, R.J. Polymastiamide A, a novel steroid/amino acid conjugate isolated from the Norwegian marine sponge Polymastia boletiformis (Lamarck, 1815). J. Org. Chem. 1993, 58, 6924-6927. [CrossRef]

139. Kong, F.; Andersen, R.J. Polymastiamides B-F, novel steroid/amino acid conjugates isolated from the Norwegian marine sponge Polymastia boletiformis. J. Nat. Prod. 1996, 59, 379-385. [CrossRef]

140. Smyrniotopoulos, V.; Rae, M.; Soldatou, S.; Ding, Y.; Wolff, C.W.; McCormack, G.; Coleman, C.M.; Ferreira, D.; Tasdemir, D. Sulfated steroid-amino acid conjugates from the Irish marine sponge Polymastia boletiformis. Mar. Drugs 2015, 13, 1632-1646. [CrossRef] [PubMed]

141. Hanssen, K.O.; Andersen, J.H.; Stiberg, T.; Engh, R.A.; Svenson, J.; Geneviere, A.M.; Hansen, E. Antitumoral and mechanistic studies of ianthelline isolated from the Arctic sponge Stryphnus fortis. Anticancer Res. 2012, 32, 4287-4297. [PubMed]

142. Shin, J.; Seo, Y.; Rho, J.R.; Baek, E.; Kwon, B.-M.; Jeong, T.S.; Bok, S.H. Suberitenones A and B: Sesterterpenoids of an unprecedented skeletal class from the Antarctic sponge Suberites sp. J. Org. Chem. 1995, 60, 7582-7588. [CrossRef]

143. Gompel, M.; Leost, M.; De Joffe, E.B.K.; Puricelli, L.; Franco, L.H.; Palermo, J.; Meijer, L. Meridianins, a new family of protein kinase inhibitors isolated from the ascidian Aplidium meridianum. Bioorg. Med. Chem. Lett. 2004, 14, 1703-1707. [CrossRef] [PubMed]

144. Appleton, D.R.; Chuen, C.S.; Berridge, M.V.; Webb, V.L.; Copp, B.R. Rossinones A and B, biologically active meroterpenoids from the Antarctic ascidian, Aplidium species. J. Org. Chem. 2009, 74, 9195-9198. [CrossRef]

145. Steffan, B. Lepadin A, a decahydroquinoline alkaloid from the tunicate Clavelina lepadiformis. Tetrahedron 1991, 47, 8729-8732. [CrossRef]

146. Kubanek, J.; Williams, D.E.; de Silva, E.D.; Allen, T.; Andersen, R.J. Cytotoxic alkaloids from the flatworm Prostheceraeus villatus and its tunicate prey Clavelina lepadiformis. Tetrahedron Lett. 1995, 36, 6189-6192. [CrossRef]

147. Diyabalanage, T.; Amsler, C.D.; McClintock, J.B.; Baker, B.J. Palmerolide A, a cytotoxic macrolide from the Antarctic tunicate Synoicum adareanum. J. Am. Chem. Soc. 2006, 128, 5630-5631. [CrossRef] 
148. Noguez, J.H.; Diyabalanage, T.; Miyata, Y.; Xie, X.-S.; Valeriote, F.A.; Amsler, C.D.; McClintock, J.B.; Baker, B.J. Palmerolide macrolides from the Antarctic tunicate Synoicum adareanum. Bioorg. Med. Chem. 2011, 19, 6608-6614. [CrossRef]

149. Miyata, Y.; Diyabalanage, T.; Amsler, C.D.; McClintock, J.B.; Valeriote, F.A.; Baker, B.J. Ecdysteroids from the Antarctic tunicate Synoicum adareanum. J. Nat. Prod. 2007, 70, 1859-1864. [CrossRef] [PubMed]

150. Tadesse, M.; Strøm, M.B.; Svenson, J.; Jaspars, M.; Milne, B.F.; Tørfoss, V.; Andersen, J.H.; Hansen, E.; Stensvåg, K.; Haug, T. Synoxazolidinones A and B: Novel bioactive alkaloids from the ascidian Synoicum pulmonaria. Org. Lett. 2010, 12, 4752-4755. [CrossRef]

151. Tadesse, M.; Svenson, J.; Jaspars, M.; Strøm, M.B.; Abdelrahman, M.H.; Andersen, J.H.; Hansen, E.; Kristiansen, P.E.; Stensvåg, K.; Haug, T. Synoxazolidinone C; a bicyclic member of the synoxazolidinone family with antibacterial and anticancer activities. Tetrahedron Lett. 2011, 52, 1804-1806. [CrossRef]

152. Tadesse, M.; Svenson, J.; Sepcic, K.; Trembleau, L.; Engqvist, M.; Andersen, J.H.; Jaspars, M.; Stensvag, K.; Haug, T. Isolation and synthesis of pulmonarins A and B, acetylcholinesterase inhibitors from the colonial ascidian Synoicum pulmonaria. J. Nat. Prod. 2014, 77, 364-369. [CrossRef] [PubMed]

153. Pettus, J.A., Jr.; Wing, R.M.; Sims, J.J. Marine natural products. XII. Isolation of a family of multihalogenated gamma-methylene lactones from the red seaweed Delisea fimbriata. Tetrahedron Lett. 1977, 18, 41-44. [CrossRef]

154. Shilling, A.J.; Von Salm, J.L.; Sanchez, A.R.; Kee, Y.; Amsler, C.D.; McClintock, J.B.; Baker, B.J. Anverenes B-E, new polyhalogenated monoterpenes from the Antarctic red alga Plocamium cartilagineum. Mar. Drugs 2019, 17, 230. [CrossRef]

155. Ankisetty, S.; Nandiraju, S.; Win, H.; Park, Y.C.; Amsler, C.D.; McClintock, J.B.; Baker, J.A.; Diyabalanage, T.K.; Pasaribu, A.; Singh, M.P.; et al. Chemical investigation of predator-deterred macroalgae from the Antarctic peninsula. J. Nat. Prod. 2004, 67, 1295-1302. [CrossRef]

156. Nedialkova, D.; Naidenova, M. Screening the antimicrobial activity of actinomycetes strains isolated from Antarctica. J. Cult. Collect. 2005, 4, 29-35.

157. Silber, J.; Ohlendorf, B.; Labes, A.; Erhard, A.; Imhoff, J.F. Calcarides A-E, antibacterial macrocyclic and linear polyesters from a Calcarisporium strain. Mar. Drugs 2013, 11, 3309-3323. [CrossRef]

158. Encheva-Malinova, M.; Stoyanova, M.; Avramova, H.; Pavlova, Y.; Gocheva, B.; Ivanova, I.; Moncheva, P. Antibacterial potential of streptomycete strains from Antarctic soils. Biotechnol. Biotechnol. Equip. 2014, 28, 721-727. [CrossRef]

159. Giudice, A.L.; Fani, R. Antimicrobial potential of cold-adapted bacteria and fungi from polar regions. In Biotechnology of Extremophiles: Advances and Challenges; Rampelotto, P.H., Ed.; Springer: Cham, Switzerland, 2016.

160. Parrilli, E.; Papa, R.; Carillo, S.; Tilotta, M.; Casillo, A.; Sannino, F.; Cellini, A.; Artini, M.; Selan, L.; Corsaro, M.M.; et al. Anti-biofilm activity of Pseudoalteromonas haloplanktis tac125 against Staphylococcus epidermidis biofilm: Evidence of a signal molecule involvement? Int. J. Immunopathol. Pharmacol. 2015, 28, 104-113. [CrossRef]

161. Bosi, E.; Fondi, M.; Orlandini, V.; Perrin, E.; Maida, I.; de Pascale, D.; Tutino, M.L.; Parrilli, E.; Lo Giudice, A.; Filloux, A.; et al. The pangenome of (Antarctic) Pseudoalteromonas bacteria: Evolutionary and functional insights. BMC Genom. 2017, 18, 93. [CrossRef] [PubMed]

162. Lipotec Antarcticine. Available online: https://www.lipotec.com/en/products/antarcticine-reg-marine-ingredient/ (accessed on 15 March 2020).

163. Lipotec SeaCode. Available online: https://www.lipotec.com/en/products/seacode-trade-marine-ingredient/ (accessed on 15 March 2020).

164. Knestrick, M.A.; Wilson, N.G.; Roth, A.; Adams, J.H.; Baker, B.J. Friomaramide, a highly modified linear hexapeptide from an Antarctic sponge, inhibits Plasmodium falciparum liver-stage development. J. Nat. Prod. 2019, 82, 2354-2358. [CrossRef]

165. Ebada, S.S.; Lin, W.; Proksch, P. Bioactive sesterterpenes and triterpenes from marine sponges: Occurrence and pharmacological significance. Mar. Drugs 2010, 8, 313-346. [CrossRef] [PubMed]

166. Elissawy, A.M.; El-Shazly, M.; Ebada, S.S.; Singab, A.B.; Proksch, P. Bioactive terpenes from marine-derived fungi. Mar. Drugs 2015, 13, 1966-1992. [CrossRef] [PubMed]

167. Hegazy, M.E.; Mohamed, T.A.; Alhammady, M.A.; Shaheen, A.M.; Reda, E.H.; Elshamy, A.I.; Aziz, M.; Pare, P.W. Molecular architecture and biomedical leads of terpenes from red sea marine invertebrates. Mar. Drugs 2015, 13, 3154-3181. [CrossRef]

168. Wu, Q.; Sun, J.; Chen, J.; Zhang, H.; Guo, Y.W.; Wang, H. Terpenoids from marine soft coral of the genus Lemnalia: Chemistry and biological activities. Mar. Drugs 2018, 16, 320. [CrossRef] 
169. McNaught, A.D.; Wilkinson, A. IUPAC Compendium of Chemical Terminology; International Union of Pure and Applied Chemistry: Hoboken, NJ, USA, 1997.

170. Ruzicka, L. The isoprene rule and the biogenesis of terpenic compounds. Experientia 1953, 9, 357-367. [CrossRef]

171. Davis, E.M.; Croteau, R. Cyclization enzymes in the biosynthesis of monoterpenes, sesquiterpenes, and diterpenes. In Biosynthesis: Aromatic Polyketides, Isoprenoids, Alkaloids; Leeper, F.J., Vederas, J.C., Eds.; Springer: Berlin/Heidelberg, Germany, 2000; pp. 53-95.

172. Leal, M.C.; Madeira, C.; Brandao, C.A.; Puga, J.; Calado, R. Bioprospecting of marine invertebrates for new natural products-a chemical and zoogeographical perspective. Molecules 2012, 17, 9842-9854. [CrossRef]

173. Amsler, C.D.; McClintock, J.B.; Baker, B.J. Chemical mediation of mutualistic interactions between macroalgae and mesograzers structure unique coastal communities along the western Antarctic Peninsula. J. Phycol. 2014, 50, 1-10. [CrossRef]

174. Kladi, M.; Vagias, C.; Roussis, V. Volatile halogenated metabolites from marine red algae. Phytochem. Rev. 2004, 3, 337-366. [CrossRef]

175. Amsler, C.D.; Iken, K.B.; McClintock, J.B.; Amsler, M.O.; Peters, K.J.; Hubbard, J.M.; Furrow, F.B.; Baker, B.J. A comprehensive evaluation of the palatability and chemical defenses of subtidal macroalgae from the Antarctic peninsula. Mar. Ecol. Prog. Ser. 2005, 294, 141-159. [CrossRef]

176. McClintock, J.B.; Baker, B.J. Marine Chemical Ecology; CRC Press: New York, NY, USA, 2001.

177. Pérez, M.J.; Falqué, E.; Domínguez, H. Antimicrobial action of compounds from marine seaweed. Mar. Drugs 2016, 14, 52. [CrossRef] [PubMed]

178. MarinLit, a Database of the Marine Natural Products Literature. Available online: http://pubs.rsc.org/marinlit/ (accessed on 3 March 2020).

179. Fraga, B.M. Natural sesquiterpenoids. Nat. Prod. Rep. 2013, 30, 1226-1264. [CrossRef]

180. Duran-Pena, M.J.; Ares, J.M.B.; Hanson, J.R.; Collado, I.G.; Hernandez-Galan, R. Biological activity of natural sesquiterpenoids containing a gem-dimethylcyclopropane unit. Nat. Prod. Rep. 2015, 32, 1236-1248. [CrossRef]

181. Choudhary, A.; Naughton, L.M.; Montanchez, I.; Dobson, A.D.W.; Rai, D.K. Current status and future prospects of marine natural products (MNPs) as antimicrobials. Mar. Drugs 2017, 15, 272. [CrossRef]

182. Bideau, F.L.; Kousara, M.; Chen, L.; Wei, L.; Dumas, F. Tricyclic sesquiterpenes from marine origin. Chem. Rev. 2017, 117, 6110-6159. [CrossRef]

183. Kato, S.; Shindo, K.; Kawai, H.; Odagawa, A.; Matsuoka, M.; Mochizuki, J. Pyrrolostatin, a novel lipid peroxidation inhibitor from Streptomyces chrestomyceticus. Taxonomy, fermentation, isolation, structure elucidation and biological properties. J. Antibiot. (Tokyo) 1993, 46, 892-899. [CrossRef]

184. Liu, D.Z.; Liang, B.W. Structural elucidation and NMR assignments of two new pyrrolosesquiterpenes from Streptomyces sp. Hd7-21. Magn. Reson. Chem. 2014, 52, 57-59. [CrossRef]

185. Bradfield, A.E.; Penfold, A.R.; Simonsen, J.L. 414. The constitution of eremophilone and of two related hydroxy-ketones from the wood oil of Eremophila mitchelli. J. Chem. Soc. 1932, 2744-2759. [CrossRef]

186. Riche, C.; Pascard-Billy, C.; Devys, M.; Gaudemer, A.; Barbier, M.; Bousquet, J.-F. Structure cristalline et moleculaire de la phomenone, phytotoxine produite par le champignon Phoma exigua var. non oxydabilis. Tetrahedron Lett. 1974, 15, 2765-2766. [CrossRef]

187. Yuyama, K.T.; Fortkamp, D.; Abraham, W.R. Eremophilane-type sesquiterpenes from fungi and their medicinal potential. Biol. Chem. 2018, 399, 13-28. [CrossRef] [PubMed]

188. Wang, L.; Li, M.; Tang, J.; Li, X. Eremophilane sesquiterpenes from a deep marine-derived fungus, Aspergillus sp. SCSIOW2, cultivated in the presence of epigenetic modifying agents. Molecules 2016, 21, 473. [CrossRef]

189. McDonald, L.A.; Barbieri, L.R.; Bernan, V.S.; Janso, J.; Lassota, P.; Carter, G.T. 07H239-A, a new cytotoxic eremophilane sesquiterpene from the marine-derived Xylariaceous fungus LL-07H239. J. Nat. Prod. 2004, 67, 1565-1567. [CrossRef] [PubMed]

190. Song, Y.; Wang, J.; Huang, H.; Ma, L.; Wang, J.; Gu, Y.; Liu, L.; Lin, Y. Four eremophilane sesquiterpenes from the mangrove endophytic fungus Xylaria sp. BL321. Mar. Drugs 2012, 10, 340-348. [CrossRef]

191. Torres, P.; Ayala, J.; Grande, C.; Anaya, J.; Grande, M. Furanoeremophilane derivatives from Senecio flavus. Phytochemistry 1999, 52, 1507-1513. [CrossRef]

192. Mohamed, A.E.-H.; Ahmed, H. Eremophilane-type sesquiterpene derivatives from Senecio aegyptius var. discoideus. J. Nat. Prod. 2005, 68, 439-442. [CrossRef]

193. Tori, M.; Otose, K.; Fukuyama, H.; Murata, J.; Shiotani, Y.; Takaoka, S.; Nakashima, K.; Sono, M.; Tanaka, M. New eremophilanes from Farfugium japonicum. Tetrahedron 2010, 66, 5235-5243. [CrossRef] 
194. Harinantenaina, L.; Matsunami, K.; Otsuka, H. Chemical and biologically active constituents of Pteris multifida. J. Nat. Med. 2008, 62, 452-455. [CrossRef]

195. Fabian, K.; Lorenzen, K.; Anke, T.; Johansson, M.; Sterner, O. Five new bioactive sesquiterpenes from the fungus Radulomyces confluens (Fr.) Christ. Z. Naturforsch. C. J. Biosci. 1998, 53, 939-945. [CrossRef]

196. Mogi, Y.; Inanaga, K.; Tokuyama, H.; Ihara, M.; Yamaoka, Y.; Yamada, K.-i.; Takasu, K. Rapid assembly of protoilludane skeleton through tandem catalysis: Total synthesis of paesslerin A and its structural revision. Org. Lett. 2019, 21, 3954-3958. [CrossRef] [PubMed]

197. Iken, K.B.; Baker, B.J. Ainigmaptilones, sesquiterpenes from the Antarctic gorgonian coral Ainigmaptilon antarcticus. J. Nat. Prod. 2003, 66, 888-890. [CrossRef]

198. Cano, L.P.P.; Manfredi, R.Q.; Pérez, M.; García, M.; Blustein, G.; Cordeiro, R.; Pérez, C.D.; Schejter, L.; Palermo, J.A. Isolation and antifouling activity of azulene derivatives from the Antarctic gorgonian Acanthogorgia laxa. Chem. Biodivers. 2018, 15, e1700425. [CrossRef] [PubMed]

199. Iken, K.; Avila, C.; Ciavatta, M.L.; Fontana, A.; Cimino, G. Hodgsonal, a new drimane sesquiterpene from the mantle of the Antarctic nudibranch Bathydoris hodgsoni. Tetrahedron Lett. 1998, 39, 5635-5638. [CrossRef]

200. Avila, C. Terpenoids in marine heterobranch molluscs. Mar. Drugs 2020, 18, 162. [CrossRef]

201. Hortelano, S. Molecular basis of the anti-inflammatory effects of terpenoids. Inflamm. Allergy Drug Targets 2009, 8, 28-39.

202. Gao, S.S.; Li, X.M.; Zhang, Y.; Li, C.S.; Wang, B.G. Conidiogenones H and I, two new diterpenes of cyclopiane class from a marine-derived endophytic fungus Penicillium chrysogenum QEN-24S. Chem. Biodivers. 2011, 8, 1748-1753. [CrossRef]

203. Du, L.; Li, D.; Zhu, T.; Cai, S.; Wang, F.; Xiao, X.; Gu, Q. New alkaloids and diterpenes from a deep ocean sediment derived fungus Penicillium sp. Tetrahedron 2009, 65, 1033-1039. [CrossRef]

204. Roncal, T.; Cordobes, S.; Sterner, O.; Ugalde, U. Conidiation in Penicillium cyclopium is induced by conidiogenone, an endogenous diterpene. Eukaryot. Cell 2002, 1, 823-829. [CrossRef]

205. Cheng, Z.; Li, Y.; Xu, W.; Liu, W.; Liu, L.; Zhu, D.; Kang, Y.; Luo, Z.; Li, Q. Three new cyclopiane-type diterpenes from a deep-sea derived fungus Penicillium sp. YPGA11 and their effects against human esophageal carcinoma cells. Bioorg. Chem. 2019, 91, 103129. [CrossRef]

206. Gonzalez, Y.; Torres-Mendoza, D.; Jones, G.E.; Fernandez, P.L. Marine diterpenoids as potential anti-inflammatory agents. Mediat. Inflamm. 2015, 2015, 263543. [CrossRef] [PubMed]

207. Dayton, P.K.; Bobilliard, G.A.; Paine, R.T.; Dayton, L.B. Biological accomodation in the benthic community at McMurdo Sound, Antarctica. Ecol. Monograph. 1974, 44, 105-128. [CrossRef]

208. Nunez-Pons, L.; Carbone, M.; Vazquez, J.; Gavagnin, M.; Avila, C. Lipophilic defenses from alcyonium soft corals of Antarctica. J. Chem. Ecol. 2013, 39, 675-685. [CrossRef]

209. Cattaneo-Vietti, R.; Chiantore, M.; Schiaparelli, S.; Albertelli, G. Shallow- and deep-water mollusc distribution at Terra Nova Bay (Ross Sea, Antarctica). Polar Biol. 2000, 23, 173-182. [CrossRef]

210. Gavagnin, M.; De Napoli, A.; Castelluccio, F.; Cimino, G. Austrodorin-A and -B: First tricyclic diterpenoid 2'-monoglyceryl esters from an Antarctic nudibranch. Tetrahedron Lett. 1999, 40, 8471-8475. [CrossRef]

211. Davies-Coleman, M.T.; Faulkner, D.J. New diterpenoic acid glycerides from the Antarctic nudibranch Austrodoris kerguelensis. Tetrahedron 1991, 47, 9743-9750. [CrossRef]

212. Arens, J.; Bergs, D.; Mewes, M.; Merz, J.; Schembecker, G.; Schulz, F. Heterologous fermentation of a diterpene from Alternaria brassisicola. Mycology 2014, 5, 207-219. [CrossRef]

213. Xu, R.; Fazio, G.C.; Matsuda, S.P. On the origins of triterpenoid skeletal diversity. Phytochemistry 2004, 65, 261-291. [CrossRef]

214. Lednicer, D. Steroid Chemistry at a Glance; Wiley: Hoboken, NJ, USA, 2010.

215. Mijts, B.N.; Lee, P.C.; Schmidt-Dannert, C. Engineering carotenoid biosynthetic pathways. Methods Enzymol. 2004, 388, 315-329.

216. Fiedor, J.; Burda, K. Potential role of carotenoids as antioxidants in human health and disease. Nutrients 2014, 6, 466-488. [CrossRef]

217. Lohr, M. Carotenoids. In The Chlamydomonas Sourcebook, 2nd ed.; Harris, E.H., Stern, D.B., Witman, G.B., Eds.; Academic Press: London, UK, 2009; Chapter 21; pp. 799-817.

218. Gonzalez, S.; Gilaberte, Y.; Philips, N.; Juarranz, A. Current trends in photoprotection-A new generation of oral photoprotectors. Open Dermatol. J. 2011, 5, 6-14. [CrossRef]

219. Galasso, C.; Corinaldesi, C.; Sansone, C. Carotenoids from marine organisms: Biological Ffunctions and industrial applications. Antioxidants 2017, 6, 96. [CrossRef] 
220. Matsuno, T. Aquatic animal carotenoids. Fish. Sci. 2001, 67, 771-783. [CrossRef]

221. Liao, L.; Su, S.; Zhao, B.; Fan, C.; Zhang, J.; Li, H.; Chen, B. Biosynthetic potential of a novel Antarctic actinobacterium Marisediminicola antarctica ZS314(T) revealed by genomic data mining and pigment characterization. Mar. Drugs 2019, 17, 388. [CrossRef] [PubMed]

222. Rodrigues, D.B.; Flores, E.M.M.; Barin, J.S.; Mercadante, A.Z.; Jacob-Lopes, E.; Zepka, L.Q. Production of carotenoids from microalgae cultivated using agroindustrial wastes. Food Res. Int. 2014, 65, 144-148. [CrossRef]

223. Da Silva, N.A.; Rodrigues, E.; Mercadante, A.Z.; de Rosso, V.V. Phenolic compounds and carotenoids from four fruits native from the Brazilian Atlantic forest. J. Agri. Food Chem. 2014, 62, 5072-5084. [CrossRef] [PubMed]

224. Gharibzahedi, S.M.T.; Razavi, S.H.; Mousavi, S.M. Characterization of bacteria of the genus Dietzia: An updated review. Ann. Microbiol. 2014, 64, 1-11. [CrossRef]

225. Guyomarc'h, F.; Binet, A.; Dufosse, L. Production of carotenoids by Brevibacterium linens: Variation among strains, kinetic aspects and HPLC profiles. J. Ind. Microbiol. Biotech. 2000, 24, 64-70. [CrossRef]

226. Wagener, S.; Volker, T.; De Spirt, S.; Ernst, H.; Stahl, W. 3,3'-Dihydroxyisorenieratene and isorenieratene prevent UV-induced DNA damage in human skin fibroblasts. Free Radic. Biol. Med. 2012, 53, 457-463. [CrossRef]

227. Kalinin, V.I.; Silchenko, A.S.; Avilov, S.A.; Stonik, V.A.; Smirnov, A.V. Sea cucumbers triterpene glycosides, the recent progress in structural elucidation and chemotaxonomy. Phytochem. Rev. 2005, 4, 221-236. [CrossRef]

228. Antonov, A.S.; Avilov, S.A.; Kalinovsky, A.I.; Anastyuk, S.D.; Dmitrenok, P.S.; Evtushenko, E.V.; Kalinin, V.I.; Smirnov, A.V.; Taboada, S.; Ballesteros, M.; et al. Triterpene glycosides from Antarctic Sea cucumbers. 1. Structure of liouvillosides A1, A2, A3, B1, and B2 from the sea cucumber Staurocucumis liouvillei: New procedure for separation of highly polar glycoside fractions and taxonomic revision. J. Nat. Prod. 2008, 71, 1677-1685. [CrossRef] [PubMed]

229. Howes, F.N. Fish-poison plants. Bull. Misc. Infor. (R. Bot. Gard. Kew) 1930, 1930, 129-153. [CrossRef]

230. Augustin, J.M.; Kuzina, V.; Andersen, S.B.; Bak, S. Molecular activities, biosynthesis and evolution of triterpenoid saponins. Phytochemistry 2011, 72, 435-457. [CrossRef] [PubMed]

231. Lorent, J.H.; Quetin-Leclercq, J.; Mingeot-Leclercq, M.P. The amphiphilic nature of saponins and their effects on artificial and biological membranes and potential consequences for red blood and cancer cells. Org. Biomol. Chem. 2014, 12, 8803-8822. [CrossRef] [PubMed]

232. Sun, H.X.; Xie, Y.; Ye, Y.P. Advances in saponin-based adjuvants. Vaccine 2009, 27, 1787-1796. [CrossRef]

233. Bahrami, Y.; Zhang, W.; Chataway, T.; Franco, C. Structure elucidation of five novel isomeric saponins from the viscera of the sea cucumber Holothuria lessoni. Mar. Drugs 2014, 12, 4439-4473. [CrossRef]

234. Antonov, A.S.; Avilov, S.A.; Kalinovsky, A.I.; Anastyuk, S.D.; Dmitrenok, P.S.; Kalinin, V.I.; Taboada, S.; Bosh, A.; Avila, C.; Stonik, V.A. Triterpene glycosides from Antarctic sea cucumbers. 2. Structure of achlioniceosides $\mathrm{A}(1), \mathrm{A}(2)$, and A(3) from the sea cucumber Achlionice violaecuspidata (=Rhipidothuria racowitzai). J. Nat. Prod. 2009, 72, 33-38. [CrossRef] [PubMed]

235. Silchenko, A.S.; Kalinovsky, A.I.; Avilov, S.A.; Andryjashchenko, P.V.; Fedorov, S.N.; Dmitrenok, P.S.; Yurchenko, E.A.; Kalinin, V.I.; Rogacheva, A.V.; Gebruk, A.V. Kolgaosides A and B, two new triterpene glycosides from the Arctic deep water sea cucumber Kolga hyalina (Elasipodida: Elpidiidae). Nat. Prod. Commun. 2014, 9, 1259-1264. [CrossRef]

236. Menna, M.; Imperatore, C.; D’Aniello, F.; Aiello, A. Meroterpenes from marine invertebrates: Structures, occurrence, and ecological implications. Mar. Drugs 2013, 11, 1602-1643. [CrossRef]

237. Hemmings, A. A question of politics: Bioprospecting and the Antarctic Treaty System. Antarctic Bioprospecting; University of Canterbury: Christchurch, New Zealand, 2005; pp. 98-129.

238. Hemmings, A. Re-Justifying the Antarctic Treaty System for the 21st Century: Rights, Expectations and Global Equity. In Polar Geopolitics: Knowledges, Resources and Legal Regimes; Edward Elgar Publishing: Cheltenham, UK, 2014; pp. 55-73.

239. Greiber, T. Access and Benefit Sharing in Relation to Marine Genetic Resources from Areas Beyond National Jurisdiction: A Possible Way Forward; Study in Preparation of the Informal Workshop on Conservation of Biodiversity Beyond National Jurisdiction. In Research Project of the Federal Agency for Nature Conservation; Bundesamt für Naturschutz: Bonn, Germany, 2011.

240. Greiber, T. An Explanatory Guide to the Nagoya Protocol on Access and Benefit-Sharing; IUCN: Gland, Switzerland, 2012.

241. Wilkinson, M.D.; Dumontier, M.; Aalbersberg, I.J.; Appleton, G.; Axton, M.; Baak, A.; Blomberg, N.; Boiten, J.-W.; da Santos, L.B.S.; Bourne, P.E.; et al. The FAIR Guiding Principles for scientific data management and stewardship. Sci. Data 2016, 3, 160018. [CrossRef] 
242. Thompson, C.C.; Kruger, R.H.; Thompson, F.L. Unlocking marine biotechnology in the developing world. Trends Biotech. 2017, 35, 1119-1121. [CrossRef] [PubMed]

243. Blasiak, R.; Jouffray, J.-B.; Wabnitz, C.C.C.; Sundström, E.; Österblom, H. Corporate control and global governance of marine genetic resources. Sci. Adv. 2018, 4, eaar5237. [CrossRef] [PubMed]

244. Hofland, P. Plitidepsin-A novel anti-cancer agent possibly active against COVID19. Onco'Zine. 2020. Available online: https://www.oncozine.com/plitidepsin-a-novel-anti-cancer-agent-possibly-active-against-covid18/ (accessed on 27 July 2020).

245. Andrade-Ochoa, S.; Nevárez-Moorillón, G.V.; Sánchez-Torres, L.E.; Villanueva-García, M.; Sánchez-Ramírez, B.E.; Rodríguez-Valdez, L.M.; Rivera-Chavira, B.E. Quantitative structure-activity relationship of molecules constituent of different essential oils with antimycobacterial activity against Mycobacterium tuberculosis and Mycobacterium bovis. BMC Complement. Altern. Med. 2015, 15, 332. [CrossRef] [PubMed]

(C) 2020 by the authors. Licensee MDPI, Basel, Switzerland. This article is an open access article distributed under the terms and conditions of the Creative Commons Attribution (CC BY) license (http://creativecommons.org/licenses/by/4.0/). 